\title{
Mixed Waste Characterization Reference Document
}

\author{
Published September 1997
}

\author{
Idaho National Engineering and Environmental Laboratory \\ Mixed Waste Focus Area \\ Lockheed Martin Idaho Technologies Company \\ Idaho Falls, Idaho 83415
}

Prepared for the

U.S. Department of Energy

Assistant Secretary for

Environmental Management

Under DOE Idaho Operations Office

Contract DE-AC07-94ID13223 


\section{DLSCLAMIER}

Portions of this dosament my be Illegible in electronic iroage products Images are produeed from the best arailable ariginal docomenter. 


\section{CONTENTS}

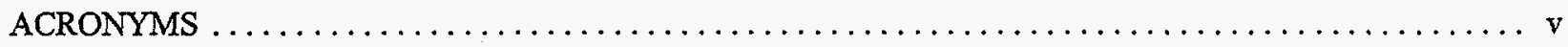

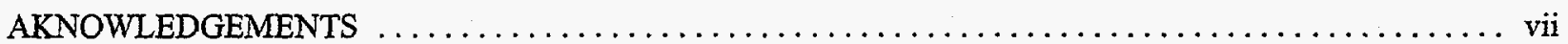

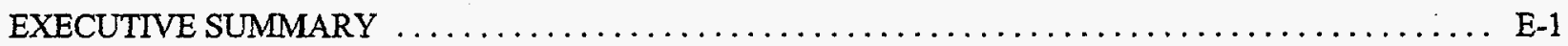

1. MIXED WASTE CHARACTERIZATION REFERENCE DOCUMENT $\ldots \ldots \ldots \ldots \ldots \ldots \ldots \ldots \ldots .1$

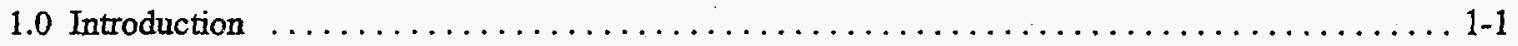

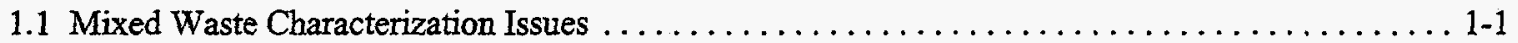

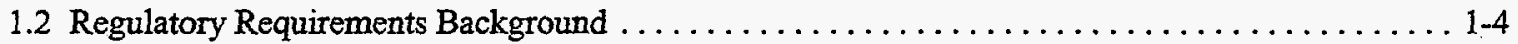

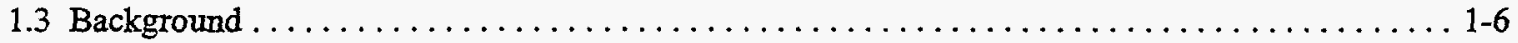

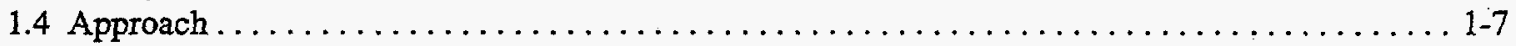

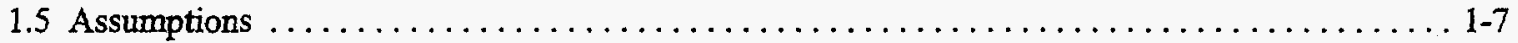

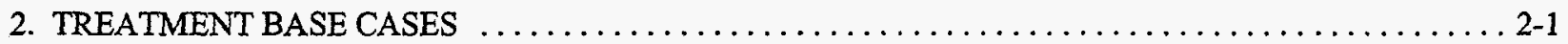

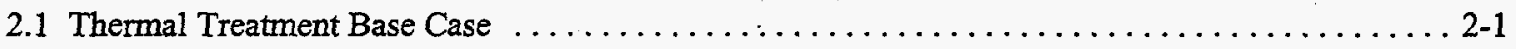

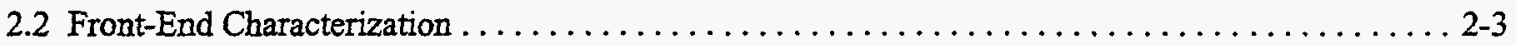

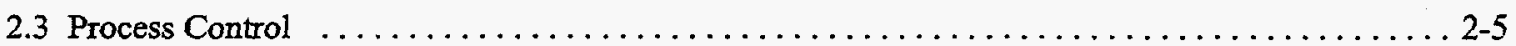

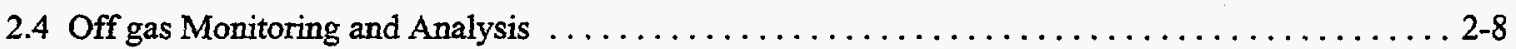

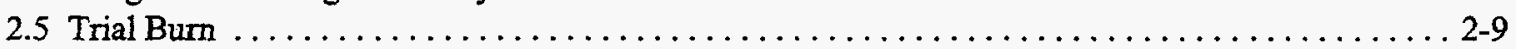

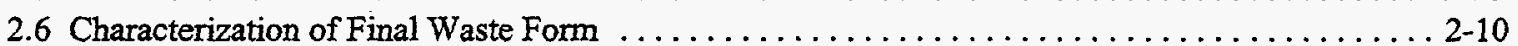

2.7 Thermal Treatment Base Case Cost Summary ............................ 2-14

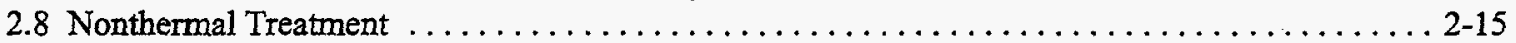

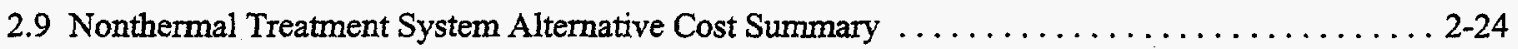

3. TREATMENT BASE CASE IMPROVEMENTS/REFINEMENTS $\ldots \ldots \ldots \ldots \ldots \ldots \ldots \ldots \ldots \ldots \ldots .1$

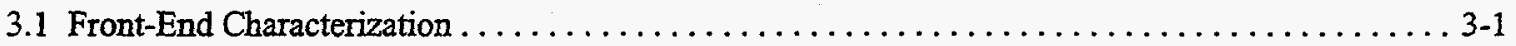

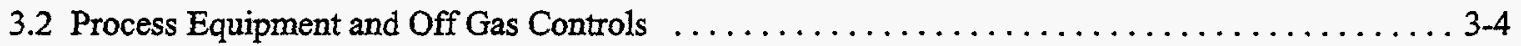

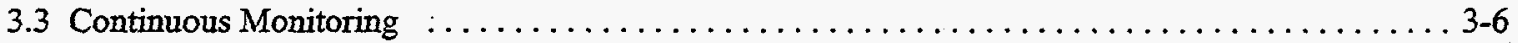

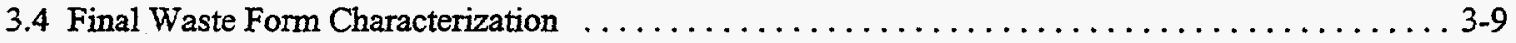

4. AN IMPROVED CHARACTERIZATION AND MONITORING CONFIGURATION $\ldots \ldots \ldots \ldots \ldots \ldots 4-1$

4.1 Improved Characterization and Monitoring Configuration Cost Summary $\ldots \ldots \ldots \ldots \ldots \ldots$ 4-3

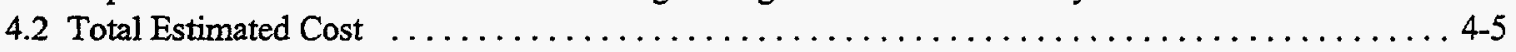




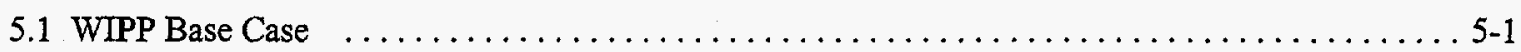

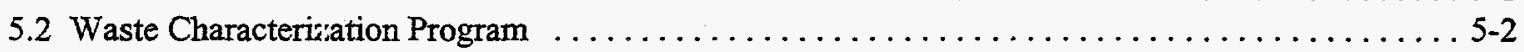

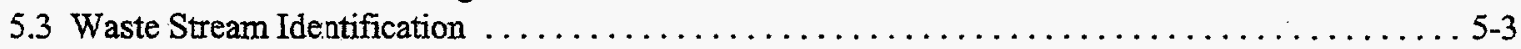

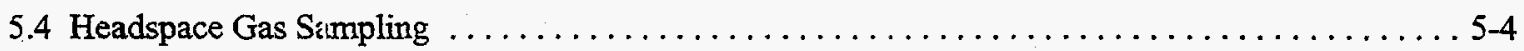

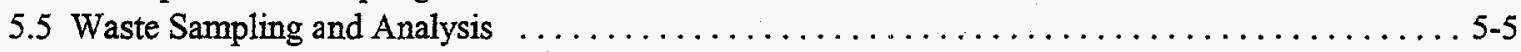

5.6 Waste Characterization Costs per 1,000 Drum Population $\ldots \ldots \ldots \ldots \ldots \ldots \ldots \ldots \ldots \ldots$

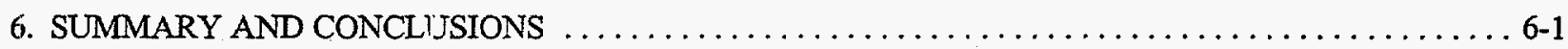

6.1 Comparison of Cests of Characterization and Monitoring $\ldots \ldots \ldots \ldots \ldots \ldots \ldots \ldots \ldots \ldots \ldots \ldots .1$

6.2 Opportunities for Cost-Effective Improvements in

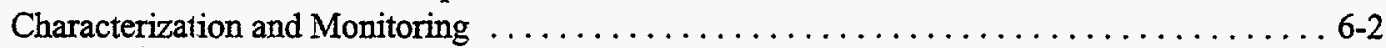

6.3 Conclusions and Fecommendations for further Action $\ldots \ldots \ldots \ldots \ldots \ldots \ldots \ldots \ldots, 6,2$

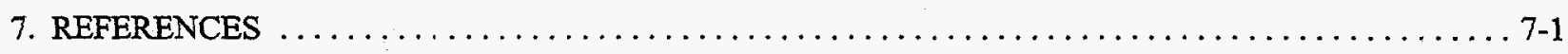

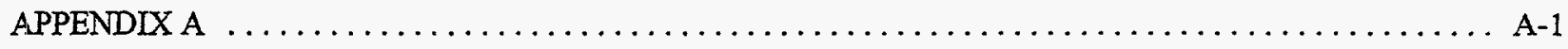

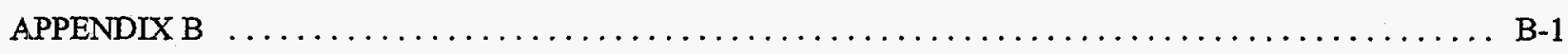

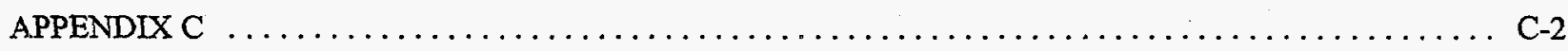




\section{ACRONYMS}

\begin{tabular}{|c|c|}
\hline $\mathbf{A E A}$ & Atomic Energy Act \\
\hline ALARA & As Low As Reasonably Achievable \\
\hline ANSI & American National Standards Institute \\
\hline $\mathbf{A P C}$ & air pollution control \\
\hline APCS & air pollution control system \\
\hline ASTM & American Society for Testing and Materials \\
\hline BIF & Boilers and Industrial Furnaces \\
\hline Btu & British Thermal Unit \\
\hline CAA & Clean Air Act \\
\hline CAO & Contract Administrative Office \\
\hline CEM & continuous emission monitor \\
\hline CERCLA & Comprehensive Environmental Response, Compensation and Liability Act \\
\hline CFR & Code of Federal Regulations \\
\hline CH TRU & contact handled transuranic waste \\
\hline $\mathrm{CO}$ & Carbon Monoxide \\
\hline CWO & Catalytic Wet Oxidation \\
\hline DDT & Benzene, 1,1'-(2,2,2-trichloroethylidene) Bis(4-Chlorobenezene) \\
\hline DOE & U.S. Department of Energy \\
\hline DRE & destruction and removal efficiency \\
\hline ECD & Electron Capture Detection \\
\hline EDE & effective dose equivalent \\
\hline EPA & U.S. Environmental Protection Agency \\
\hline FFCA & Federal Facility Compliance Act \\
\hline FGE & Fissile gram equivalent \\
\hline FTE & full time equivalent \\
\hline FTIR & Fourier Transform Infrared Spectroscopy \\
\hline GC & gas chromatography \\
\hline GPCR & Gas Phase Corona Reactor \\
\hline HAP & Hazardous Air Pollutant \\
\hline HEPA & high efficiency particulate air \\
\hline INEEL & Idaho National Engineering \& Environmental Laboratory \\
\hline INTS & Integrated Nonthermal Treatment System \\
\hline LDR & Land Disposal Restriction \\
\hline LVM & Low Volatile Metals \\
\hline MACT & maximum achievable control technology \\
\hline MS & mass spectroscopy \\
\hline MWFA & Mixed Waste Focus Area \\
\hline MWIR & Mixed Waste Inventory Report \\
\hline NDA & non-destructive assay \\
\hline NDE & non-destructive examination \\
\hline NDIR & non-dispersive infrared \\
\hline NDUV & non-dispersive ultraviolet \\
\hline NESHAP & National Emission Standards for Hazardous Air Pollutants \\
\hline NMED & New Mexico Environmental Division \\
\hline NOx & Nitrogen Oxides \\
\hline
\end{tabular}


NPDES

NRC

NSPS

NTW

PAN

PCB

PEIS

PGNAA

PIC

PM

POHC

PREPP

PVCs

QA

QAPP

RCRA

RTR

RWMC

SARP

SCC

SOPs

SOX

SVM

SVOC

SWEPP

TCLP

TD

TDS

T'HC

TOC

TRD

TRU

TSCA

TSD

UTS

VOC

VOST

WAC

WIPP

WTWBIR
National Pollution Discharge Elimination System

U.S. Nuclear Regulatory Commission

New Source Performance Standards

National Technical Workshop on Thermal Treatment Technologies

Passive and Active Neutron

polychlorinated biphenyl

Progranmatic Environmental Impact Statement

prompt gamma neutron activation analysis

Product of Incomplete Combustion

particulate matter

Principal Organic Hazardous Constituent

Process Experimental Pilot Plant

Polyvinyl chlorides

Quality Assurance

Quality Assurance Program Plan

Resource Conservation and Recovery Act

Real Tirne Radiography

Radioactive Waste Management Complex

Safety Analysis Report for Packaging

Secondary Combustion Chamber

Standard Operating Procedures

Sulfur Oxides

semi-volatile metals

semi-volatile organic compound

Stored Waste Examination Pilot Plant

Toxic Characteristic Leaching Procedure

technology development

Total Disisolved Solids

Total Hydrocarbon

Total Organic Carbon

Technical Resource Document

transuranic waste

Toxic Substances Control Act

treatment, storage or disposal

Universal Treatment Standards

volatile organic compound

volatile organic sampling train

Waste Arceptance Criteria

Waste Isolation Pilot Plant

Waste Isolation Pilot Plant Transuranic Waste Baseline Inventory Report 


\section{ACKNOWLEDGMENTS}

Expertise in a broad variety of subjects including waste treatment, off gas system design, RCRA regulation, waste characterization, nondestructive assay, and continuous emissions monitoring was required to generate this report. The Mixed Waste Focus Area assembled a team of experts to support this effort and acknowledge the significant contributions of individual members. These members include Peggy Hinman, Kliss McNeel, Peggy Knecht, Dave Eaton, Charles Marcinkiewicz, Nick Soelberg, Steve Priebe, Greg Becker and Mike Connolly. 


\section{DISCLAIMER}

This report was prepared as an account of work sponsored by an agency of the United States Government. Neither the United States Government nor any agency thereof, nor any of their employees, makes any warranty, express or implied, or assumes any legal ljability or responsibility for the accuracy, completeness, or usefulness of any information, apparatus, product, or process disclosed, or represents that its use would not infringe privately owned rights. Reference herein to any specific commercial product, process, or service by trade name, trademark, manufacturer, or otherwise does not necessarily constitute or imply its endorsement, recommendation, or favoring by the United States Government or any agency thereof. The views and opinions of authors expressed herein do not necessarily state or reflect those of the United States Government or any agency thereof. 


\section{Executive Summary}

Waste characterization and monitoring are major activities in the management of waste from generation through storage and treatment to disposal. Adequate waste characterization is necessary to ensure safe storage, selection of appropriate and effective treatment, and adherence to disposal standards. For some wastes, characterization objectives can be difficult and costly to achieve. The purpose of this document is to evaluate costs of characterizing one such waste type, mixed (hazardous and radioactive) waste.

The bulk of the nation's mixed waste is located at facilities owned or operated by the U.S. Department of Energy (DOE). The DOE faces unique challenges in characterizing and monitoring its mixed wastes due to three factors.

The first factor is the presence of radioactive constituents in the hazardous waste. DOE orders and requirements govern management of the radioactive aspects of mixed waste, while the hazardous component is governed by Environmental Protection Agency (EPA) Resource Conservation and Recovery Act (RCRA) laws and regulation. At times, this dual regulatory scheme results in conflicts in handling mixed waste.

The second factor is the heterogeneous (or varied) nature of a substantial percentage of waste. The regulatory requirement is to make treatment and disposal decisions based upon a representative sample of waste. Obtaining a representative sample of alpha-mixed wastes (such as debris stored in containers) remains physically difficult due to the layers of containment required to handle alpha contamination as well as questions concerning a heterogeneous waste type.

The third factor is the application of current characterization requirements to alpha-mixed "legacy" waste generated as a result of DOE operations from the 1950 s to the late 1980 s. Prior to the $1970 \mathrm{~s}$, these wastes were land-disposed and will be dispositioned as part of DOE site environmental restoration and decommissioning. Alpha-mixed wastes generated from 1970 to the present were placed into storage. Process and historical knowledge of the waste streams provides a basis for storage, but does not provide adequate characterization information required for treatment by current environmental regulations.

Substantial effort has been devoted to achieving a better understanding of the characterization and monitoring issues associated with mixed waste and how these issues affect treatment and disposal decisions. For example, DOE, EPA and state regulators are engaged in cooperative efforts to examine the issues through a National Technical Workgroup on Mixed Waste Incineration. DOE and EPA have held technical meetings and issued reports on characterization and monitoring for mixed waste. DOE has formed the Mixed Waste Focus Area (MWFA) as the responsible entity for resolution of technological, regulatory, and public acceptance barriers to new treatment technologies and new disposal waste forms. The MWFA is specifically charged with solving the problem of the lack of accepted characterization technologies and treatment technologies.

These efforts have led to a better understanding of the difficulties associated with mixed waste characterization. However, information critical to resolving the problem was needed. A systematic approach to identifying characterization requirements, defining baseline costs and methods for achieving requirements, and assessing impacts of improved or changed methods was required. This document is intended to provide that systems approach and to yield data upon which further decisions can be made. 
This document addresses characterization costs under two scenarios: treatment and disposal at a permitted disposal facility or: Waste Isolation Pilot Plant (WIPP), and disposal directly to the WIPP. For purposes of this document, characterization is defined to include monitoring where monitoring is a supplement or substitute for characterization.

Under the treatment scenaric, costs are broken into four categories: front-end characterization, process monitoring and off gas control, continuous emission monitoring (CEM), and final waste form characterization. This docurnent first establishes the costs of characterization when waste is treated in a baseline treatment system, disfined as a rotary kiln incinerator. Next, treatment in a nonthermal system is evaluated from the standpoir.t of characterization costs. Then, improvements to specific aspects of the base case treatment system vhich would result in improved characterization results, techniques or approaches are discussed and evaluated for their potential to achieve costs savings or fill technology gaps. Finally, an 'ideal' characterization and monitoring configuration representing the results of implementing selected improvements is discussed.

Under the disposal at WIPP scenario, costs of characterization to allow direct disposal at WIPP are evaluated. The WIPP data forms a basis for comparison to the requirements for waste characterization associated with treatment. F:gure E-1 depicts the approach taken to accomplish this study.

The following assumptions regarding the waste were established in order to arrive at costs and allow for comparison of costs:

- $\quad$ The waste to be evaluated consists of 1,000 drums of mixed heterogeneous waste and sludge. For purposes of comparison across the various scenarios, it is assumed that 10 pircent of the waste will be characterized prior to treatment.

- Thirty percent of the drums contain sludge. Seventy percent of the drums contain heterogeneous waste (i.e., debris). One composite sample is assumed for each sludge wiaste drum that is sampled. Debris is sampled at the rate of three samples per drum due to the nature of these waste types.

- $\quad$ The material being sampled and analyzed is contaminated with TRU radionuclides. All analyses are performed so as to avoid radioactive contamination and exposure to hazardous materials. This requirement includes the use of engineered barriers such as a glove box, but does not require extensive shielding (i.e., "remote handling").

Costs for sampling and analysis have been estimated for individual samples requiring analysis in a glove box. Costs associated with these analyses are based upon use of an on-site laboratory and reflect the Idaho National Engineering and Environmental Laboratory's (INEEL) experience with sampling and analysis of transuranic wastes.

Table E-1 summarizes the costs of characterization under the various scenarios assessed in this report. Note that the WIPP case shou.d not be compared directly to the cases involving treatment in terms of whether WIPP is ultimately more cost-effective. WIPP costs reflect only costs to characterize waste for compliance with WIPP Waste Acceptance Criteria (WAC) prior to disposal. Costs to characterize waste for any treatment required in order to meet the WIPP WAC are not included. 
Costs for characterization for non-thermal treatment are more than for thermal treatment because of the additional characterization associated with multiple process steps, and because of the increased number of drums generated through the non-thermal treatment process. Compared to the thermal base case, costs of front end and final waste form characterization under the 'improved' configuration are less while costs of off gas monitoring and analysis are higher.

The area of greatest cost reduction under the improved configuration is for final waste form characterization, where costs are reduced by 70 percent due to volume reduction achieved through treatment and due to elimination of sampling for those WIPP WAC requirements which would not apply to a treated waste form. Costs of front end characterization under the improved configuration are reduced by 20 percent due to use of nonintrusive/nondestructive techniques, process and off gas controls, and continuous emission monitors. This amount of savings can be significant given the number of drums to be processed. However, the costs of opening a drum to conduct sampling and analysis contribute to the greatest portion of the costs of characterization under any of the scenarios.

The greatest opportunity for cost savings under each of the scenarios lies in reducing the number of drums to be opened for sampling and analysis. This opportunity can only be realized through a strategy which provides process certainty for every waste parameter of concern. For example, development of non-intrusive techniques for sampling for metals solves one of the characterization issues. If drums must still be opened for other purposes, then the maximum cost savings cannot be achieved. Best results would be achieved through pursuit of a cohesive strategy which relies upon non-intrusive sampling and assay for radionuclides and metals, combined with methods for assuring that organics are within acceptable ranges. This approach would be coupled with a means of evaluating the data received to determine the amount of sampling needed. This overall strategy would allow for reduction of sampling and analysis costs over the long term as process operations and waste streams are better understood. For example, the percentage of characterization may be reduced from ten percent to five percent or even one percent. Short term gains would also be received as alternative techniques can be substituted for current laboratory analytical methods.

Although development work and discussions with the regulatory community must be continued to realize cost savings, improvements have the potential to address those unique aspects of mixed waste that create difficulties when applying standard characterization methods. Nonintrusive methods or continuous monitoring can reduce worker exposure and can substitute for feed stream or waste analysis obtaining a representative sample of heterogeneous waste. Finally, the characterization needs for a particular management approach can be tailored to that approach and continually reviewed to determine how the desired performance objectives can be met most efficiently.

The assessment of costs and potential improvements provided in this document can be used to evaluate the cost-effectiveness of alternative scenarios, identify technology gaps, identify opportunities to improve existing technology, identify and prioritize future technology development (TD) efforts, and evaluate the regulatory acceptance of proposed alternatives. The documented baseline for characterization/monitoring technologies for treatment and disposal systems provides the costs of meeting base case characterization requirements and allows for cost comparisons of alternative approaches. With this baseline, technology needs can be identified and assessed, and the most promising characterization alternatives can be identified for further development. 
Step 1 Define Existing Characterization Requirements

* Front-End

Characterization
* Process

Monitoring
* Off Gas

Monitoring
* Final Waste Form Characterization

Sts:p 2 Identify Costs for Meeting Requirements for:

* Thermal Treatment System

* Non-Thermal Treatment System

* Disposal at WIPP

Step 3 Identify Improvements

* Front-End Characterization -At-line Non-Destructivie Assay -Bulk Assay
* Process Monitoring * Off Gas Monitoring * Final Waste Form Criticality Engineering Continuous Emission Characterization

* Off Gas Control: Monitor for: -Mercury $-\mathrm{HC} 1, \mathrm{Cl} 2$
-WIPP WAC for treated waste
-Metals

$-\mathrm{HCl} / \mathrm{Cl} 2$

-Mercury

Stipp 4 Incomorate Improvements and Assess Costs

* Improved Configuration

-Use of non-destructive characterization

-Robust thermal unit

-Improved Off Gas controls

-Additional CEMs

Figure E-1 Characterization Process Study Development

Table E-1 Costs for Charaterization and Monitoring Scenarios evaluated in this study

\begin{tabular}{|l|r|r|r|r|r|}
\hline & $\begin{array}{c}\text { Front End } \\
\text { Characterization }\end{array}$ & $\begin{array}{c}\text { Process } \\
\text { Monitoring } \\
\text { \& Off gas } \\
\text { Control }\end{array}$ & $\begin{array}{c}\text { Off Gas } \\
\text { Monitoring } \\
\& \text { Analysis }\end{array}$ & $\begin{array}{r}\text { Characterization } \\
\text { of Final Waste } \\
\text { Form }\end{array}$ & $\begin{array}{c}\text { Total to } \\
\text { Nearest } \$ 1000\end{array}$ \\
\hline Thermal Base Case & $\$ 2,387,000$ & $\$ 56,000$ & $\$ 125,000$ & $\$ 1,755,000$ & $\$ 4,323,000$ \\
\hline Non-Thermal System & $\$ 12,626,000$ & $\$ 56,000$ & $\$ 125,000$ & $\$ 3,421,000$ & $\$ 16,228,000$ \\
\hline $\begin{array}{l}\text { Improved } \\
\text { Configuration }\end{array}$ & $\$ 1,896,000$ & $\$ 56,000$ & $\$ 208,000$ & $\$ 556,000$ & $\$ 2,716,000$ \\
\hline WIPP & $\$ 1,755,000$ & N/A & N/A & N/A & $\$ 1,755,000$ \\
\hline
\end{tabular}




\section{Mixed Waste Characterization Reference Document}

\subsection{Introduction}

Waste characterization and monitoring are major activities in the management of waste from generation through storage and treatment to disposal. Adequate waste characterization is necessary to ensure safe storage, selection of appropriate and effective treatment, and adherence to disposal standards. For some wastes characterization objectives can be difficult and costly to achieve. The purpose of this document is to evaluate costs of characterizing one such waste type, mixed (hazardous and radioactive) waste.

For the purpose of this document, waste characterization includes treatment system monitoring, where monitoring is a supplement or substitute for waste characterization. This document establishes a cost baseline for mixed waste characterization and treatment system monitoring requirements from which to evaluate alternatives. This baseline can be used to evaluate the cost-effectiveness of alternative characterization scenarios, identify technology gaps, identify opportunities to improve existing technology, prioritize and identify future technology development (TD) efforts, and evaluate the regulatory acceptance of proposed alternatives. The documented baseline for characterization/monitoring technologies for treatment and disposal systems provides the costs of meeting base case characterization requirements and allows for cost comparisons of alternative approaches. With this baseline, technology needs can be identified and assessed, and the most promising characterization alternatives can be identified for further development.

The cost baseline established as part of this work includes costs for a thermal treatment technology (i.e., a rotary kiln incinerator), a nonthermal treatment process (i.e., waste sorting, macronencapsulation, and catalytic wet oxidation), and no treatment (i.e., disposal of waste at the Waste Isolation Pilot Plant (WIPP)). The analysis of improvement over the baseline includes assessment of promising areas for technology development in front-end waste characterization, process equipment, off gas controls, and monitoring. Based on this assessment, an ideal characterization and monitoring configuration is described that minimizes costs and optimizes resources required for waste characterization.

\subsection{Mixed Waste Characterization Issues}

The bulk of the nation's mixed waste is located at facilities owned or operated by the U.S. Department of Energy (DOE). The National Technical Work group (NTW) on Mixed Waste Incineration developed the Technical Resource Document for Mixed Waste Characterization for Thermal Treatment Systems, (April 1997) which recognizes the difficulties of characterizing mixed waste. This document was used in this study as a resource for information and possible approaches to solving the issues surrounding characterization of containerized alpha-mixed waste. Figure 1-1 illustrates the general process of mixed waste characterization and treatment, and provides a basis for assessing these factors discussed below. The DOE faces unique challenges in characterizing and monitoring its mixed wastes due to three factors.

The first factor is the presence of radioactive constituents in the hazardous waste. DOE orders and requirements govern management of the radioactive aspects of mixed waste, while the hazardous component is governed by Environmental Protection Agency (EPA) Resource Conservation and Recovery Act (RCRA) laws and regulation. At times, this dual regulatory scheme results in conflicts in 
handling mixed waste. For example, DOE policy establishes goals of maintaining worker exposure to radiation as low as reasonably achievable (ALARA) and to minimize the effects on the environment from radiation, while hazardous waste requirements often involve intrusive sampling methods that increase the amount of waste handling required to meet characterization objectives. As a result, use of commonly accepted or required methods of characterization can be problematic due to concerns about worker and environmental radiological exposure and waste minimization. To address these concerns, sampling and analysis must te conducted under enhanced control processes (e.g. as using containment), increasing costs for each step in the process relative to normally incurred costs. This is particularly true when alpha-emitting radionuslides are the source of radioactive contamination. Costs are also increased due to additional monitoring requirements to address criticality concerns, as in processing alpha-mixed waste (hazardous waste containing alpha-emitting radionuclides $[>10 \mathrm{nCi} / \mathrm{g}]$, excluding remote-handled $[>200 \mathrm{mR} / \mathrm{hr}])$. This subset of mixed waste is the particular focus of this document.

The second factor is the heterogeneous (or varied) nature of a substantial percentage of waste. The regulatory requirement is to make treatment and disposal decisions based upon a representative sample of waste. It is relatively easy to obtain a representative sample that exhibits the average properties of homogeneous wastes such as wastewater so that treatment/disposal plans can be established and followed. Obtaining a representative sample of heterogenous (e.g. debris) waste is extremely difficult and is additionally complex for alpha contaminated waste due to the radiological containment required for handling. DOE mixed waste inventory information estimates that treatment capacity must be developed for over $57,000 \mathrm{~m}^{3}$ of alpha-mixed debris and for nearly $58,000 \mathrm{~m}^{3}$ of alpha-mixed homogeneous sludges. In adclition, characterization issues have hampered treatment decisions for over $9,000 \mathrm{~m}^{3}$ of alpha-mixed debris and for $800 \mathrm{~m}^{3}$ of alpha-mixed sludges. These two waste streams account for 78 percent of the mixed waste in the DOE complex for which treatment capacity must be developed, or for which furthor characterization is needed (MWFA Technical Baseline Report, DOE/ID10524, April, 1997).

The third factor is the applicalion of current characterization requirements to alpha-mixed "legacy" waste generated as a result of DOE operations from the 1950 s to the late 1980 s. Prior to the 1970 s, these wastes were land-disposed and will be dispositioned as part of DOE site environmental restoration and decommissioning. Alpha-mixed wastes generated from 1970 to the present were placed into storage. Process and historical knowleige of the waste streams provides a basis for storage, but does not provide the amount of characterizatior information required for treatment by current environmental regulations. 


\section{Upfront Characterization Activities}

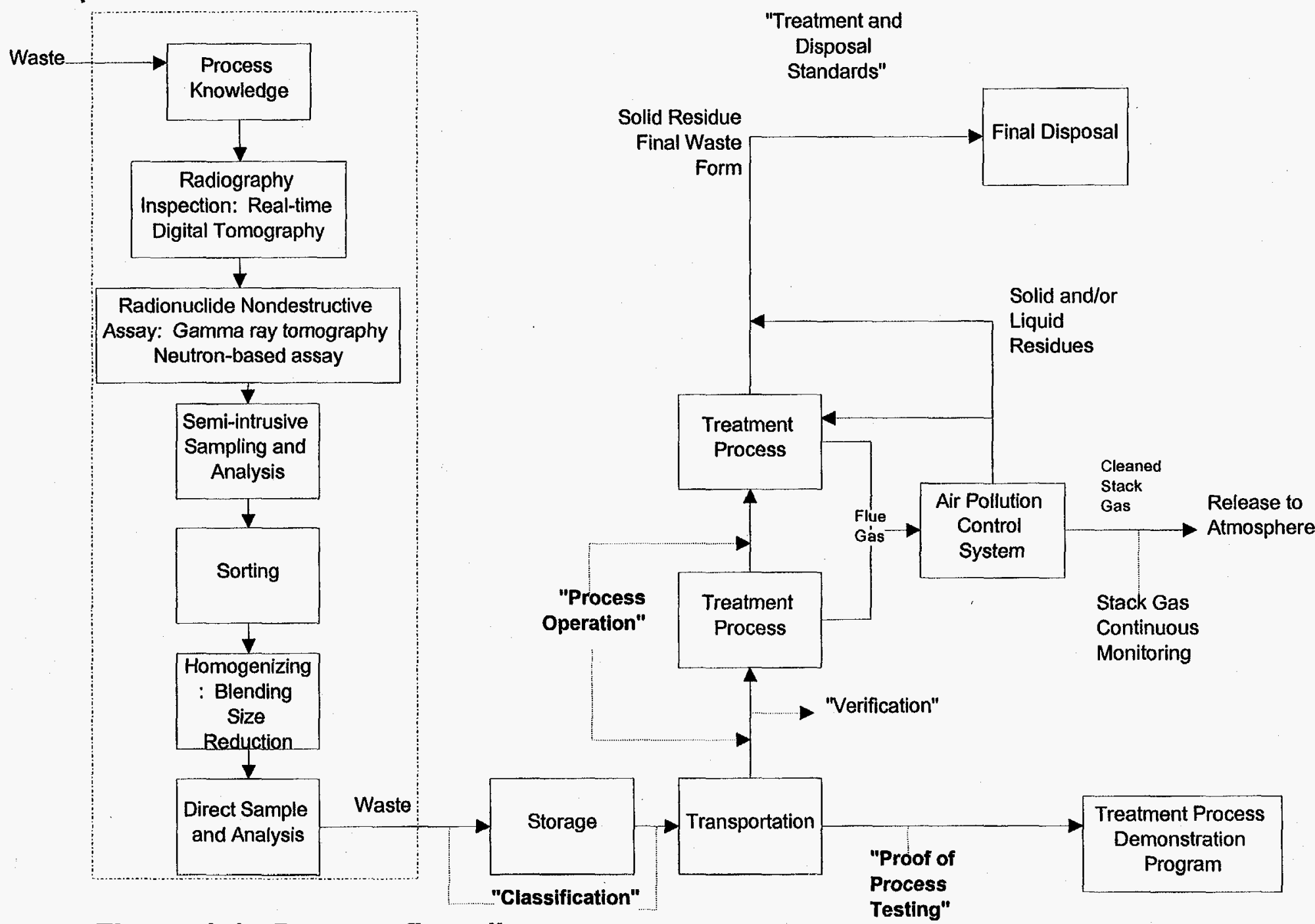

Figure 1-1. Process flow diagram (adapted from the Technical Resource Document for Mixed Waste Characterization for Thermal Treatment Systems, (April 1997) Figure B-1) 


\subsection{Regulatory Requirements Background}

The waste characterization baseline and alternatives must satisfy multiple regulatory programs at the national and state levels. Facilities treating hazardous waste are regulated under the Resource Conservation and Recovery Act (RCRA), and the Clean Air Act (CAA). If the wastes also contain PCB's then facilities are also regulated under the Toxic Substances Control Act (TSCA). All three of these programs require permits to operate applicable waste treatment facilities. Alternatively, the WIPP Land Withdrawal Act that was amended in September 1996 exempts wastes disposed of at the WIPP from the RCRA land disposal restrictions. The DOE is not required to treat mixed wastes or demonstrate compliance with the "no migration" standards prior to disposal of mixed waste at the WIPP facility. TRU waste characterization requirements for the WIPP facility address operational and safety requirements, transportation requirements, and environmental compliance requirements associated with the WIPP RCRA permit and the certificate of compliance for 40 CFR Parts 191 and 194.

\subsubsection{RCRA}

The RCRA regulations address the treatment, storage, and disposal (TSD) of hazardous waste as defined in 40 CFR Part 261. As such, mixed waste thermal and nonthermal treatment systems must be permitted under RCRA. Permitting recpuirements for incinerators are found in 40 CFR 264, Subpart $O$, and for nondirect fired thermal treatrnent systems in 40 CFR 264, Subpart X. Appendix A contains information on regulatory requirements for thermal treatment. For purposes of this document, it is assumed that nonthermal treatment systems are subject to similar off gas limits and performance requirements as thermal treatment systems.

In the private sector and for waste currently generated by the DOE, the characterization activities required prior to further waste management decisions are conducted as an integral part of the waste generation and management process. Subpart B of RCRA 40 CFR 261 addresses hazardous waste characterization requirement: applicable to all hazardous waste treatment, storage, and disposal facilities. Process knowledge may provide adequate waste characterization for treatment decisions. However more often, a detailed physical and chemical analysis of a representative waste sample is obtained prior to waste treatment and managernent. A representative sample is defined as a sample that exhibits the average properties of the waste. This analysis is typically done by the waste generator.

During the permitting proces!; the treatment facility must conduct a formal emissions test, referred to as a trial burn. A trial burn is used to establish waste feed limits and facility operating conditions which result in acceptable air emissions and waste treatment. Detailed emission measurements are conducted during the trial burn to show that pollutants such as metals and dioxins/furans are not emitted to the atmosphere at levels exceedirig regulatory limits. Following the successful trial burn, the facility shall not be operated outside of the operating envelope or with waste feeds that exceeds the defined feed limits. To do so would constitute a permit violation, even though there may not be emissions data that shows that air emission limits were exceeded. Periodically acceptable emissions must be demonstrated in subsequent testing.

The Federal Facility Compliance Act (FFCA) was enacted in 1992, as an amendment to the Solid Waste Disposal Act (SWDA) now more commonly referred to as RCRA. This law recognized the difficulties 
DOE sites were having in developing treatment capacity for mixed waste and provided a three year period for sites to establish treatment plans and schedules for mixed waste. Site treatment plans have been in place for most DOE sites since October 1995, and the sites are now subject to enforcement actions for noncompliance with those plans. Therefore, mixed waste can no longer be stored indefinitely. To accomplish safe and effective treatment and disposal of mixed waste, DOE sites must identify and pursue characterization and monitoring approaches that are accepted by the regulators and that can be implemented in accordance with site treatment plan schedules and support existing or new treatment technologies.

\subsubsection{TSCA}

The TSCA regulates the handling, use, storage, and disposal (i.e., treatment) of polychlorinated biphenyls (PCBs), which are known to be present in some DOE waste. TSCA regulations are contained in 40 CFR Part 761, and provide standards similar to requirements for RCRA facilities. Emission standards are established for PCBs (with a destruction and removal efficiency [DRE] of 99.9999 percent required), $\mathrm{HCl}$, and combustion efficiency (using continuous emission monitors [CEMs] to monitor carbon monoxide $[\mathrm{CO}]$ and carbon dioxide $\left[\mathrm{CO}_{2}\right]$ emissions). The TSCA also requires a trial burn to demonstrate the above standards and to collect data on nitrogen oxide emissions, chlorinated organic emissions, and particulate emissions. Following regulatory agency acceptance of the trial burn data, operating conditions are established in a manner similar to the RCRA.

\subsubsection{CAA}

An incinerator may be regulated under several CAA regulations ( 40 CFR Part 60 and 61) and RCRA regulations both prior to construction and during operation. Key programs include New Source Performance Standards (NSPSs), National Emission Standards for Hazardous Air Pollutants (NESHAPs), Prevention of Significant Deterioration (PSD), Hazardous Air Pollutants (HAPs), and operating permit (Title V) requirements. Permitting standards vary and are dependent on the incinerator's potential to emit a given pollutant and on the host state's specific regulatory requirements. CEMs may be required to demonstrate routine compliance with $\mathrm{NO}_{\mathrm{x}}$ and $\mathrm{SO}_{2}$ emissions limits. Periodic testing for other constituents may also be required. Monitoring limits on other constituents depends on the waste being treated.

\subsubsection{Radionuclides}

Standards for emissions of radionuclides are addressed in 40 CFR Part 61 Subpart H. Emissions standards for facilities licensed by the Nuclear Regulatory Commission (NRC) are listed in 40 CFR 61 Subpart I. The requirements of both Subpart $\mathrm{H}$ and I include the measurement of radionuclide emission rates that, with flow rate information, can be converted to emitted curies per day. The effluent flow rate shall be measured using Method 2 of Appendix A of 40 CFA Part 60 . The emitted radionuclides shall be measured using principles of measurement such as those found in 40 CFR 61 Appendix B Method 114.

DOE currently regulates management and disposal of radioactive waste under the Atomic Energy Act. Therefore, DOE orders govern the radioactive characterization and monitoring requirements for mixed waste. Transportation of mixed waste is regulated by the Nuclear Regulatory Commission (NRC). The WIPP waste acceptance criteria (WAC) address the characterization requirements for transportation of waste to the WIPP to assure NRC standards are met. 


\subsubsection{Regulatory Changes}

Anticipated regulatory changes must also be considered. On April 19, 1996, the EPA proposed extensive changes to the requirements for thermal treatment units under both RCRA and the CAA. These rules are intended to apply to new units constructed after the date of the proposed rule and to existing units within three years of finalization of the rule. These new requirements have been proposed under dual authority of the CAA and RCRA to avoid regulatory inconsistencies. The new proposed rules, which set Maximum Achievable Control Technology (MACT) standards for hazardous waste combustion units, place increased emphasis on the use of CEMs to establish compliance with the standards and impose more stringent emission limits on several pollutants emitted by such units. A summary of these standards is included in Appendix A, section A-3, page A-5.

These rules are not yet final and the approach and requirements could change. However, it appears that the proposed rules may provide a more performance-based climate for regulatory acceptance of a thermal treatment system that attempts to trade off front-end waste characterization with increased emissions control and continuous monitoring. These rules will not be the basis for the base case in the report because the DOE does not yet have such systems in place.

\subsection{Background}

Substantial efforts have been made to better understand characterization and monitoring issues associated with mixed waste and how these issues affect treatment and disposal decisions. The DOE established the MWFA as the responsible entity for resolution of technological, regulatory, and public acceptance barriers to new treatment technologies and new disposal waste forms. The MWFA is specifically charged with solving the problem of the lack of accepted characterization technologies and treatment technologies.

The MWFA developed a systematic approach that utilized input from the FFCA site treatment plans, mixed waste inventory report, site surveys, and MWFA technical experts to assess DOE's characterization, treatment, and disposal plans and needs. This resulted in a technology development baseline directed toward reso.ution of 30 key deficiencies hampering successful characterization, treatment, and disposal of mixed waste (MWFA Technical Baseline Report, DOE/ID-10524, April 1997). Several deficiencies in the areas of characterization and monitoring were identified through this prioritization process.

EPA's Characterizing Containerized Mixed Low-Level Waste for Treatment, (EPA 1993), contains several recommendations for further work on issues of characterization and monitoring addressed by this document, such as the relative benefits of up-front characterization versus versatile process design versus in-process monitoring/control. This document evaluates these issues and what technologies may result in cost savings.

The DOE, EPA, and state regulators also participate in the NTW on Mixed Waste Incineration. This work group produced documents such as the April 1997 Technical Resource Document (TRD), "Mixed Waste Characterization for Thermal Treatment Systems." This TRD's discussion of how a "robust" system could be configured ard what alternative or innovative characterization and monitoring techniques might be acceptable to the regulators was used to establish the alternative case of a robust 
system presented in this document.

These efforts have led to a better understanding of the difficulties associated with mixed waste characterization. However, information critical to resolving the problem was needed. A systematic approach to identifying characterization requirements, defining baseline costs and methods for achieving requirements, and assessing impacts of improved or changed methods was required. This document is intended to provide that systems approach and to yield data upon which further decisions can be made.

\subsection{Approach}

This document addresses characterization costs under two scenarios: treatment and disposal at a permitted disposal facility or WIPP, and disposal directly to the WIPP. For purposes of this document, characterization is defined to include monitoring where monitoring is a supplement or substitute for characterization.

Under the treatment scenario, costs are broken into four categories: front-end characterization, process monitoring and off gas control, continuous emission monitoring, and final waste form characterization. The document first establishes the costs of characterization when waste is treated in a baseline treatment system, defined as a rotary kiln incinerator. Next, treatment in a nonthermal system is evaluated from the standpoint of characterization costs. Then, improvements to specific aspects of the base case treatment system which would result in improved characterization results, techniques or approaches are discussed and evaluated for their potential to achieve costs savings or fill technology gaps. Finally, a 'ideal' characterization and monitoring configuration representing the results of implementing selected improvements is discussed.

Under the disposal at WIPP scenario, costs of characterization to allow direct disposal at WIPP and an alternative statistical approach are evaluated. The WIPP data forms a basis for comparison to the requirements for waste characterization associated with treatment. Figure 1-2 depicts the approach taken to accomplish this study.

A detailed cost analysis of each component of a characterization system including research, development, installation, and improvements is not within the scope of this document. Costs identified in this document are based on past and current Idaho National Engineering and Environmental Laboratory (INEEL) TRU waste characterization experience and estimates of researchers familiar with the systems described and proposed instrumentation.

\subsection{Assumptions}

The following wastes assumptions are defined for the purpose of this document. The waste assumptions were based on INEEL distribution of alpha-contaminated waste types, INEEL experience with sampling drums of alpha-contaminated waste, information from the Mixed Waste Inventory Report (MWIR) on the amount and types of alpha-mixed waste, experience with DOE incinerator operations, and contact with operators of commercial incinerators. Under actual test conditions, these numbers may change. It is anticipated that the percentage of waste characterized for verification could decrease once system operation was proven and the range of each measured parameter in the waste stream was established and 
shown to fall within permitted operational and emissions parameters. These assumptions are utilized for comparison purposes only.

1. The waste to be evaluated consists of 1,000 drums of mixed heterogeneous waste and sludge; characterization data meet minimum requirements (i.e., contents are known and RCRA waste codes have been identified).

2. It is assumed that 10 percent of the waste will be characterized prior to treatment for waste verification purposes. The actual percentage of waste to be characterized will depend upor. the extent of process knowledge for each particular waste stream and the presence of constituents of concern. The amount of 10 percent was selected for purposes of comparison across the various scenarios.

3. Thirty percent of the drums contain sludge. Seventy percent of the drums contain heterogeneous waste (i.e., debris). One composite sample of the sludge waste per drum will be taken. Debris is sampled at the rate of three samples per drum due to the nature of these wasle types.

4. The material being sampled and analyzed is contaminated with TRU radionuclides. All analyses are performed so as to avoid worker contamination and exposure to hazardous materials. T.iis requirement includes the use of engineered barriers such as a glove box, but does not require extensive shielding (i.e., "remote handling").

5. All 1,000 drums will be subjected to radiography to confirm the absence of prohibited materials (such as aerosol cans and gas bottles) and to qualitatively identify waste items prior to any intrusive sampling. Costs for radiography are based on INEEL Stored Waste Exam nation Pilot Plant (SWEPP) operational costs. Front-end sorting of known or suspected prohibited items is necessary following radiography (i.e., gas cylinders, lead bricks, and containers of mercury). All drums will be subjected to nondestructive assay. Costs for radioassay are based on INEEL SWEPP operational costs.

Sampling costs are based on Argonne National Laboratory - West (ANL-W) operational cost in support of INEEL's TRU Waste Characterization Program. Costs for analysis have been estimated for individual radioactively contaminated samples requiring analysis in a glove box. Costs are current for the types of sampling and analyses listed. Appendix $B$ gives a table detailing these costs.

While it is necessary to understand the cost of each management option, the choice of one management option over another may be dictated by prioritization factors other than cost. Some of those factors include waste form, ALARA, implementation risk, regulatory changes or restraints, and system complexity. 
Step 1 Define Existing Characterization Requirements

* Front-End

* Process

Characterization

Monitoring

* Off Gas

* Final Waste Form

Monitoring

Characterization

Step 2 Identify Costs for Meeting Requirements for:

* Thermal Treatment System

* Non-Thermal Treatment System

* Disposal at WIPP

* Front-End Characterization

-At-line Non-Destructive

Assay

-Bulk Assay
Step 3 Identify Improvements

* Process Monitoring * Off Gas Monitoring * Final Waste Form Criticality Engineering Continuous Emission Characterization

* Off Gas Control: Monitor for: -Mercury

-Metals -WIPP WAC for treated waste

Step 4 Incorporate Improvements and Assess Costs

* Improved Configuration

-Use of non-destructive characterization

-Robust thermal unit

-Improved Off Gas controls

-Additional CEMs

Figure 1-1 Characterization Process Study Development 


\section{Treatment Base Cases}

\subsection{Thermal Treatment Base Case}

The rotary kiln incinerator base case was selected as a benchmark for thermal treatment of mixed waste because of the long term operational history of rotary kiln incinerators for the treatment of low-level mixed and hazardous wastes. Rotary kiln technology is also well established and relatively well accepted by state and federal regulators for hazardous waste. In addition, rotary kiln incinerators have been thoroughly described and assessed by the DOE in past studies. The Programmatic Environmental Impact Statement (PEIS) for DOE Waste Management used rotary kilns in its analysis of environmental impacts. The DOE Integrated Thermal Treatment Study also reviewed rotary kilns and compared them to other thermal systems. Different types of solids, sludges, and liquids can be used as feed materials in existing feed systems. In general, the cost associated with treatment of hazardous waste in rotary kiln incinerators is well documented and can be used as a reference mark for other treatment technologies.

The DOE alpha-mixed waste has not yet been treated by incinerators due, in part, to the waste characterization, criticality, and containment issues addressed in this document. The wastes are not fully characterized for incineration, show a high degree of variability with regard to both waste form and hazardous constituents, and are contaminated with alpha-emitting radionuclides. Thus, characterization requirements for the "base case" approach for the DOE's alpha-mixed waste may be more stringent and expensive than what is observed at commercial hazardous waste facilities or at current DOE low-level mixed waste incinerators. Figure $2-1$ is a thermal systems flowchart (generalized for all thermal systems) describing basic system components and their respective characterization needs.

\subsubsection{System Description}

The base case incinerator system consists of shredding and sorting units/stations, a conventional rotary kiln, air combustion gas, and a dry-wet air pollution control (APC) system (per the Integrated Thermal Treatment System Study - Phase 2 Results [Feizollahi et al., 1994]). The APC system also includes an off gas filtration unit composed of water jets to partially quench the gas stream followed by dry filtration using a baghouse or ceramic filters. This is followed by a wet gas-scrubbing unit composed of a complete water quench, thence hydrosonic and packed bed scrubbers for removal of acid gases. Wet scrubbing is followed by gas reheating above its dewpoint, carbon absorption for dioxin and mercury control, and HEPA filtration. $\mathrm{NO}_{\mathrm{x}}$ control may be added if necessary. 


\begin{tabular}{|c|c|c|c|c|c|}
\hline & & & & $\begin{array}{c}\text { Monitoring } \\
\text { to } \\
\text { Atmosphere } \\
4\end{array}$ & \\
\hline $\begin{array}{l}\text { Waste Receipt } \\
\text { IClassification }\end{array}$ & $\begin{array}{c}\text { Waste } \\
\text { Preparation for } \\
\text { Treatment }\end{array}$ & Treatment & $\begin{array}{c}\text { Secondary } \\
\text { Oxidation }\end{array}$ & $\begin{array}{l}\text { Off gas } \\
\text { Treatment } \\
\text { System }\end{array}$ & $\begin{array}{l}\text { Final Waste } \\
\text { Form(s) } \\
\text { Handling and } \\
\text { Certification }\end{array}$ \\
\hline $\begin{array}{l}\text { Characterlzatlon Needs: } \\
\text { 1. Meet WAC? } \\
\text { 2. Physlcal Limils (sizing. } \\
\text { blending. segregation) }\end{array}$ & $\begin{array}{l}\text { Characterization Needs: } \\
\text { 1. Verly treatmant } \\
\text { approach } \\
\text { 2. Determina segregation. } \\
\text { staging, blending processes } \\
\text { 3. Conflim wasta within } \\
\text { operating window } \\
\text { 4. Phystcal, chemical, } \\
\text { and radloogical propertles }\end{array}$ & $\begin{array}{l}\text { Characterization Needs: } \\
\text { 1. Maintain operating envelope } \\
\text { 2. Erisure complate } \\
\text { destruction of organics } \\
\text { 3. Ensure immoblilization } \\
\text { of Inorganics }\end{array}$ & $\begin{array}{l}\text { Monltoring Needs: } \\
\text { 1. Maintain operalling envelope } \\
\text { 2. Ensure complete } \\
\text { destructlon of organics }\end{array}$ & $\begin{array}{l}\text { Monitoring Needs: } \\
\text { 1. Malntaln operating envelope } \\
\text { 2. Ensure removall } \\
\text { destruction of } \\
\text {-chlorine } \\
\text {-mercury } \\
\text {-particulates } \\
\text {-organlcs } \\
\text { PCBs }\end{array}$ & $\begin{array}{l}\text { Characterizatlon Needs: } \\
\text { 1. Meet Dlsposal Facillyy } \\
\text { WAC? } \\
\text { 2. Meet LDR requirements }\end{array}$ \\
\hline $\begin{array}{l}\text { Expected types of } \\
\text { characterizatlon: } \\
\text { 1. Fingerprint analysis } \\
\text { 2. RTR } \\
\text { 3. Gamma Scan } \\
\text { 4. Container properties }\end{array}$ & $\begin{array}{l}\text { Expected types of } \\
\text { characterization: } \\
\text { 1. RTR, Gamma Scan, PAN } \\
\text { 2. Presence of non. } \\
\text { conlorming llams } \\
\text { 3. Mass, Chlorine, ash, BTU. } \\
\text { melals, and volatile } \\
\text { radioniuctides } \\
\text { 4. Proximale analysis of } \\
\text { C, H, N, O, S, Cl, and } \\
\text { slag-tormers }\end{array}$ & $\begin{array}{l}\text { Expected types of } \\
\text { characterization: } \\
\text { 1. Feadrate } \\
\text { 2. Flowrale } \\
\text { 3. Temperalure } \\
\text { 4. Pressure }\end{array}$ & $\begin{array}{l}\text { Expected types of } \\
\text { monitoring: } \\
\text { 1. Temperature } \\
\text { 2. Flowrate } \\
\text { 3. Pressure }\end{array}$ & $\begin{array}{l}\text { Expected types of } \\
\text { monitoring: } \\
\text { 1. Pressure differential } \\
\text { 2. Temperature } \\
\text { 3. Pollutant breakthough }\end{array}$ & $\begin{array}{l}\text { Expected types of } \\
\text { characterization: } \\
\text { 1. TCLP } \\
\text { 2. Total Motals } \\
\text { 3. Total Organlcs. }\end{array}$ \\
\hline $\begin{array}{l}\text { Expected characterization } \\
\text { requirements: } \\
\text { 1. MostWAC }\end{array}$ & $\begin{array}{l}\text { Expected characterization } \\
\text { requirements: } \\
\text { 1. Meet limits establlshed } \\
\text { in trial burn or equilvalent }\end{array}$ & $\begin{array}{l}\text { Expected characterization } \\
\text { requirements: } \\
\text { 1. Meet limits established } \\
\text { in tral bum or equivalent } \\
\text { 2. Residence lime }\end{array}$ & $\begin{array}{l}\text { Expected monitoring } \\
\text { requirements: } \\
\text { 1. Meet limils established } \\
\text { in lirial burn or equivalent }\end{array}$ & $\begin{array}{l}\text { Expected monittoring } \\
\text { requirements: } \\
\text { 1. Chlorine < } 4 \text { lbs.hr or } 99 \% \\
\text { 2. PCBs > } 99.9999 \% \text { ORE } \\
\text { 3. Particiluate .08 g/dsct } \\
\text { 4. CO } 100 \mathrm{ppm} \\
\text { 5. THC } 20 \mathrm{ppm} \\
\text { 6. Melals (based on risk } \\
\text { assessment) }\end{array}$ & $\begin{array}{l}\text { Expected characterization } \\
\text { requirements: } \\
\text { 1. Meet LDR IImilts } \\
\text { eslablished in 40CFR268.40 } \\
\text { 2. Meet UTS IImilts } \\
\text { establlshed in 40CFR268.48 }\end{array}$ \\
\hline
\end{tabular}

Figure 2.1 Thermal Treatment System Characterization Requirements 


\subsection{Front-End Characterization}

This section details the cost of characterization conducted prior to treatment. Costs in this section reflect the costs incurred by the receiving facility in conducting a verification program. Facilities receiving low-level mixed or hazardous waste require the waste generator to provide a detailed manifest of both the chemical and physical nature of the waste prior to accepting the waste at the treatment facility. Often, this may require extensive characterization on the part of the generator, including a list of all applicable RCRA hazardous waste codes as well as additional information necessary for incineration, such as physical form, density, radioactive material content, Btu value, chlorine content, and ash content. Additionally, the generator must certify that the waste does (or does not) meet RCRA Land Disposal Restrictions (LDRs), contain pressurized containers, explosives, or other prohibited materials; and meets the facility's waste acceptance criteria (WAC). However, as discussed in Section 1, these generator activities have not been conducted for much of DOE's legacy mixed waste which is now in storage. This document assumes that generator activities will not be conducted and provides costs for 10 percent verification. If additional verification or characterization is required in a specific case, costs can be determined based on the costs provided in this document.

For the base case incinerator, 100 percent of the drum/waste feed will be subjected to radiography and non destructive assay (NDA) techniques. For purposes of this document it is assumed that analyses for ignitability, corrosivity, reactivity, PCBs, viscosity, and Btu content are required for sludges only. Both debris and sludges will be analyzed for organics, metals, ash content, and alpha, beta and gamma.

All radionuclides and fission/activation products found in the waste must be quantified to ensure compliance with criticality control and personnel exposure protection plans. A process input TRU mass assessment device is required to both verify generator data and ensure a large bolus of fissile material is not unknowingly introduced into the system. Controlling process input based on containerized waste NDA methods may not provide the desired degree of accuracy upon which to base criticality control. A more detailed description of NDA capabilities is provided in Appendix C. It is feasible with current technologies to design gross screening devices conservatively calibrated to give a threshold mass value for a good portion of the debris wastes. This may not be applicable to the sludge waste form. A gross screen can be used to eliminate containers highly loaded with TRU. A more accurate radionuclide measure must be acquired after sizing and prior to introduction into the incinerator. A secondary screening system design may be necessary to detect material in excess of the control limit. A means of stopping the feed, extracting the large undesirable quantity of fissile material, and separately managing the material is necessary.

An NDA verification system can be developed based on existing technology. Such a system must accommodate 55-gallon drums of debris and sludge wastes. Based on existing technology, this will require a gamma spectroscopy system and implementation of neutron assay techniques with active and passive modes. The precise system type, analysis technique, and implementation configuration (i.e., segmented gamma scan, tomographic gamma scan, shuffler, DDT, etc.) cannot be specified at this time. However, approximate cost estimates for operation of a system are based on ongoing studies and past work such as cost estimates for the DOE INEEL Process Experimental Pilot Plant (PREPP).

Table 2-1 shows the estimated cost to sample 10 percent of the waste feed based on the above-stated assumptions for characterization. 
Table 2-1 Costs for front end characterization of 1,000 containers - themal base case

\begin{tabular}{|c|c|c|c|c|c|c|c|c|c|c|}
\hline Task/Analysis & Method & \begin{tabular}{|c|} 
Fraction of \\
drums \\
analyzed
\end{tabular} & $\begin{array}{l}\text { No. of } \\
\text { sludge } \\
\text { drums }\end{array}$ & $\begin{array}{c}\text { No. of } \\
\text { analyses } \\
\text { per sludge } \\
\text { drum }\end{array}$ & $\begin{array}{l}\text { No. of } \\
\text { debris } \\
\text { drums }\end{array}$ & \begin{tabular}{|c|} 
No. of \\
analyses per \\
debris drum
\end{tabular} & $\begin{array}{c}\text { Total no. } \\
\text { of drums/ } \\
\text { analyses }\end{array}$ & $\begin{array}{l}\text { Sampling/ } \\
\text { Analysis } \\
\text { cost/each }\end{array}$ & $\begin{array}{l}\text { Sampling/ } \\
\text { Analysis Cost } \\
\text { actual }\end{array}$ & $\begin{array}{c}\text { Sampling/ } \\
\text { Analyses Cost } \\
\text { rounded }\end{array}$ \\
\hline Take samples & Sampling/Analysis Plan & 0.1 & 30 & 1 & 70 & 3 & 100 & $\$ 12,000$ & $\$ 1,200,000$ & $\$ 1,200,000$ \\
\hline Ignitability & SW 846 Method 1010 & 0.1 & 30 & 1 & & & 30 & $\$ 100$ & $\$ 3,000$ & $\$ 3,000$ \\
\hline Corrosivity & SW 846 Method 1011 & 0.1 & 30 & 1 & & & 30 & $\$ 46$ & $\$ 1,380$ & $\$ 1,000$ \\
\hline Organics & 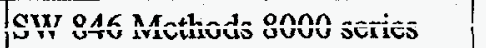 & 0.1 & 30 & $\mathbf{i}$ & 70 & $\overline{3}$ & 240 & $\$ 1,021$ & $\$ 245,040$ & $\$ 245,000$ \\
\hline Metals & SW 846 Methods 6010 and 7470 & 0.1 & 30 & 1 & 70 & 3 & 240 & $\$ 366$ & $\$ 87,840$ & $\$ 88,000$ \\
\hline PCBs & SW 846 Method 8080 or 8081 & 0.1 & 30 & 1 & & & 30 & $\$ 275$ & $\$ 8,250$ & $\$ 8,000$ \\
\hline Chlorine & SW 846 Method 9056 & 0.1 & 30 & 1 & 70 & 3 & 240 & $\$ 137$ & $\$ 32,880$ & $\$ 33,000$ \\
\hline Btu & ASTM D3286-91a & 0.1 & 30 & 1 & & & 30 & $\$ 3,240$ & $\$ 97,200$ & $\$ 97,000$ \\
\hline Viscosity & ASTM D445-88 & 0.1 & 30 & 1 & & & 30 & $\$ 165$ & $\$ 4,950$ & $\$ 5,000$ \\
\hline Alpha, beta, gamma & Lab SOPs & 0.1 & 30 & 1 & 70 & 3 & 240 & $\$ 1,014$ & $\$ 243,360$ & $\$ 243,000$ \\
\hline Radiography & Lab SOPs & 1 & 300 & 1 & 700 & 1 & 1000 & $\$ 44$ & $\$ 44,000$ & $\$ 44,000$ \\
\hline NDA (PAN) & Lab SOPs & 1 & 300 & 1 & 700 & 1 & 1000 & $\$ 44$ & $\$ 44,000$ & $\$ 44,000$ \\
\hline NDA (gamma) & Lab SOPs & 1 & 300 & 1 & 700 & 1 & 1000 & $\$ 198$ & $\$ 198,000$ & $\$ 198,000$ \\
\hline Total & & & & & & & & & $\$ 2,388,100$ & $\$ 2,387,000$ \\
\hline
\end{tabular}




\subsection{Process Control}

Process control monitoring may be required by either federal or state permitting agencies and is needed for safe and efficient operation. Some of these process control requirements such as Btu and chlorine content, are addressed as part of front-end characterization or off gas monitoring. Process monitoring and analysis are also conducted by the operating facility for its own process control needs and to potentially lower emissions. Additional requirements are present for treatment of mixed waste due to criticality concerns. This document addresses costs for conducting criticality control monitoring.

Criticality safety is the prevention or termination of inadvertent nuclear chain reactions in nonreactor environments. The "American National Standard for Nuclear Criticality in Operations with Fissionable Materials Outside Reactors" (ANSI/ANS-8.1-1983) presents general criteria and specifies numerical limits for certain simple single fissile units. The standard delineates the double-contingency principle, which calls for controls that ensure that no single mishap, regardless of its probability of occurrence, can lead to a criticality.

Process holdup of special nuclear materials found in transuranic (TRU) mixed waste is a safety and criticality control issue that must be considered in the design of a thermal waste treatment process. Holdup refers to the unintentional deposition of special nuclear material, fissile material, in or on process equipment. Monitoring and assay of holdup is necessary for criticality control and calculating material balances. Three possible control philosophies are to: 1) use process holdup monitoring, material balance, and feedrate information for control: 2) incorporate poisons in the system (i.e., boric acid solution to prevent fission reactions, via neutron absorption); and 3) design the process with critically safe pipings, vessel geometries, and the operational process modes that inherently cannot produce conditions for criticality.

Facility design will be impacted by criticality considerations. In practice, it is not physically possible to design a thermal waste treatment system in which all components are inherently safe due to passive criticality control features. Consequently, the hierarchy recommended when geometrically safe equipment is not practical is engineering, process, and administrative controls, in that order. Geometrically favorable equipment and neutron absorbers are considered to be process controls. Human-based administrative controls are always of lowest preference. Hence, the method for criticality control will be a compromise between safe/favorable process components geometries and holdup monitoring/material balance accounting procedures.

If it is not possible to prove that a criticality event is not credible, a criticality control plan must be developed. Criticality control plan considerations involve characterization of the input fissile material mass, holdup in the various process components of the system, and characterization of the process output such that mass balance assessments can be made. The two most important criticality control plan factors for the rotary kiln incineration system are the input fissile material concentration of the feed material and process holdup.

\subsubsection{Secondary Combustion Chamber (SCC)}

System size and materials of construction generally make continuous holdup monitoring of a secondary combustion chamber impractical. It is recommended that the chamber be designed such that there are no ledges or horizontal surfaces where particulate can accumulate. For the base case incinerator, it is 
assumed the secondary combustion chamber has been properly designed with respect to particulate holdup and that monitoring requirements are limited to manual methods performed during operational phases.

\subsubsection{Wet/Dry APC System. Monitoring Considerations}

An APC system consists of dry and wet off gas cleaning components. All system components and their interconnections must be evaluated for holdup/deposition potential for the potential transfer of holdup to another location during normal or off-normal conditions. Where the deposition rate is slow and the total holdup quantity is limited due to physical characteristics of the component, periodic manual external monitoring may be used. Where holdup can accumulate in large quantities at relatively rapid rates, installed monitoring systems will be necessary. In those locations where water is involved as in quenching and scrubbing operations, process vessel and pipe size must be of specific sizes or monitoring systems will be required.

Due to the radiation emission characteristics of TRU material, external monitoring of process holdup requires specific process design features. In general, such features as thin process confinement walls, small geometries, and strict temperature control requirements conflict with conventional process system design for this type of system. Where the process cannot be modified to accommodate NDA systems, such systems in general become more complex, expensive, and difficult to precisely state measurement uncertainties. Hence, favorable geometry vessels and the prevention of conditions requisite to a criticality are desired.

Full Quench--The physical design of the full quench dictates whether continuous holdup monitoring is required. For the base case dissign, the quencher is assumed to be a straight-through device that affords little area for holdup deposition. Although holdup is not an issue with the quencher, this is the point where aqueous fluids are introduced to the process and, hence, where allowable concentrations and amounts of fissile materials in this unit drop dramatically.

The quench and scrub solutions, with dissolved and suspended solids, eventually all drain to a aqueous waste treatment system. There are various phases of this mixture ranging from sludge to clean solution. Regardless, the potential for producing fissile material concentrations sufficient for a criticality are more of a reality in aqueous systems than in dry systems. Geometrically favorable vessels and piping are the preferred process devices in the aqueous solution surge and treatment system. Monitoring cost estimates are therefore, not provided.

Packed Bed Adsorber/Nucleator--This is a slow accumulation type system with a process sump requiring periodic external manual monitoring. For the base case incinerator, it is assumed the design of the adsorber/nucleator cannot be sufficiently changed to satisfy criticality safety concerns and that continuous external monitoring of the sump cannot be eliminated.

Hydrosonic Scrubber--The liydrosonic scrubber itself requires no holdup monitoring device due to its design. The piping associated with the system should be geometrically favorable in the event of system upsets where the entire piping could become flooded. As with the quencher, the hydrosonic scrubber is interconnected to the scrub solution transfer and treatment system. Based on criticality and probabilistic risk analyses, various comporents of this system will require some sort of continuous monitoring unless all piping and vessels are designed in critically safe configurations. Criticality safe configurations are not assumed for the base case. 
Mist Eliminator--This is a slow accumulation type system that likely can be managed via periodic external manual monitoring. The present design has a process sump that will have to be redesigned or be outfitted with monitoring devices. For the base case incinerator, it is assumed the design of the mist eliminator cannot be changed sufficient to satisfy criticality safety concerns and that external monitoring of the sump is required.

Scrub Solution and Aqueous Waste Treatment System--There are several potential candidates for a monitoring system for large sump and surge tanks. Each method must be carefully evaluated with respect to the tank geometry, dimensions, and composition of the solution, density. Several types of subcritical reactivity measurements can be performed such as pulsed neutron and ${ }^{252} \mathrm{Cf}$ source driven noise analysis methods. In addition, more standard gamma/neutron passive measurement methods may be applied, depending on the specifics of the vessel and the nature of the solution contained therein.

Carbon Filter--Without much knowledge of the configuration of a carbon filter system, the allowable concentrations of TRU will be carefully considered due to the moderating properties of graphite/carbon. The simple addition of water to a carbon filter system with sufficient quantities of TRU may quickly approach an established safety limit. Hence, continuous monitoring will be required either on or upstream of this system.

HEPA Filters--HEPA filters will be changed out prior to the accumulation of significant concentrations of TRU materials. Periodic external manual monitoring such as pressure drops will suffice for this system. The costs for such undefined systems are not included in this analysis.

Table 2-2 Summary of costs for process monitoring control-base case.

Table 2-2 Summary of costs for process monitoring - thermal base case

\begin{tabular}{|l|r|}
\hline \multicolumn{1}{|c|}{ Task/Monitoring Activity } & \multicolumn{1}{c|}{$\begin{array}{c}\text { Cost of Operation } \\
\text { (1000 drums) }\end{array}$} \\
\hline Packed Bed Adsorber/ Nucleator & $\$ 5,000$ \\
\hline Aqueous Solution Treatment System & $\$ 30,000$ \\
\hline Mist Eliminator & $\$ 16,000$ \\
\hline Carbon filter & $\$ 5,000$ \\
\hline Total & $\$ 56,000$ \\
\hline
\end{tabular}

\subsection{Off gas Monitoring and Analysis}

In the combustion process, organic constituents in waste are oxidized to form $\mathrm{CO}_{2}$ and water vapor. Because carbon monoxide $\mathrm{CO}$ is a product of incomplete combustion, monitoring off gas for the absence of $\mathrm{CO}$ provides an indicator that high required combustion efficiencies are achieved to fully destroy hazardous organics. Inorganic waste constituents (such as ash, halogens, sulfur, nitrogen, phosphorus, and metals) exit the combustion process either unchanged or in oxidized forms. These inorganic constituents form combustion products that are often considered air pollutants. Because inorganic constituents are not converted to $\mathrm{CO}_{2}$ and water in the combustion process, waste feed characterization provides a direct indication of maximum potential emissions. 
Commercial Continuous Emission Monitor (CEM) or at-line instrumentation is presently available for the continuous emissions monitoring of $\mathrm{SO}_{2}, \mathrm{NO}_{x}, \mathrm{HCl}$, chlorine gas, mercury, and gross radiation. Where CEMs are used, monitoring feedback is typically rapid and continuous. Therefore, monitoring results can be used to control or adjust feed rates to maintain regulated constituents below emission compliance limits. In extractive type stack gas monitoring technologies the samples are often remotely located from the stack at a pcint where specific samples are collected. A sample is drawn through a heated sample line to the CEIM room, where the sample is filtered to remove particulate and dried to remove water. The stack gas is then analyzed for constituents of concern.

Analyzers are operated continuously (thus the term CEMs) and they have a high (greater than 99 percent) on-stream factor. However, lailures can occur due to plugging of the sample probe in the stack, plugging of the sample filter, or failure of the sample drier. For these reasons, where on-stream availability is critical, redundant CEMs and sampling systems are specified.

Radiation monitors may be of the in-stack or extractive type. In-stack monitors can be used to measure the concentrations of gamma.ray-emitting radionuclides. However, activity release concentrations are usually measured from extracted samples. Extractive systems can measure gross gamma/beta on particulate filters, iodine, and radiogases by locating them close to the stack to minimize accumulation of particulate matter in the sampling line.

The approximate costs of various CEMs system components are presented in Table 2-3. These costs are based on vendor statements, usage, and component cost estimates. 
Table 2-3 Equipment and annual operating costs for off gas monitoring and analysis - base case

\begin{tabular}{|c|c|c|}
\hline & $\begin{array}{c}\text { Equipment Price } \\
\text { to Nearest } \\
\$ 1,000\end{array}$ & $\begin{array}{c}\text { Operating costs } \\
\text { to Nearest } \\
\$ 1,000 \\
\end{array}$ \\
\hline Two sample probes & $\$ 10,000$ & \\
\hline Calibration Gas system & $\$ 10,000$ & \\
\hline $\begin{array}{l}\text { CEM Monitoring and Control } \\
\text { System }\end{array}$ & $\$ 30,000$ & \\
\hline Strip Chart Recorder & $\$ 20,000$ & $\$ 26,000$ \\
\hline CO Analyzers & $\$ 6,000$ & $\$ 8,000$ \\
\hline $\mathrm{O}_{2}$ Analyzers & $\$ 10,000$ & $\$ 8,000$ \\
\hline $\mathrm{CO}_{2}$ Analyzers & $\$ 5,000$ & $\$ 8,000$ \\
\hline NOx Analyzer & $\$ 10,000$ & $\$ 8,000$ \\
\hline $\begin{array}{l}\text { THC Analyzer/Probe/Heated Sample } \\
\text { Line }\end{array}$ & $\$ 10,000$ & $\$ 10,000$ \\
\hline Opacity Meter & $\$ 18,000$ & $\$ 10,000$ \\
\hline $\mathrm{HCl}$ Analyzer & $\$ 12,000$ & $\$ 8,000$ \\
\hline Radiation & $\$ 200,000$ & $\$ 22,000$ \\
\hline CEM Building & $\$ 170,000$ & \\
\hline Spare Parts, 1 yr operation & $\$ 5,000$ & \\
\hline Total & $\$ 516,000$ & $\$ 108,000$ \\
\hline
\end{tabular}

\subsection{Trial Burn}

A comprehensive initial compliance trial burn test that may encompass RCRA, TSCA, and CAA requirements is required for incinerators processing radioactive and hazardous waste. This testing program must be repeated every five to ten years as directed by an operating permit. A trial burn may involve the collection of numerous samples over the test period, along with data from CEMs. The RCRA regulations establish emissions limits on low volatility and semi-volatile metals, $\mathrm{HCl}$, chlorine, particulate, and CO. Destruction and Removal Efficiency (DRE) is demonstrated during a trial burn on two or more organic constituents that are representative of the most difficult to destroy organic constituents in the waste. Off gas monitoring is required for oxygen and $\mathrm{CO}$. Total hydrocarbons in the off gas can be monitored in lieu of $\mathrm{CO}$ if $\mathrm{CO}$ cannot be maintained below $100 \mathrm{ppm}$ dry volume corrected to 7 percent oxygen. Stack sampling for organics, metals, $\mathrm{HCl}, \mathrm{Cl}_{2}, \mathrm{THC}, \mathrm{NO}_{\mathrm{x}}, \mathrm{CO}, \mathrm{CO}_{2}, \mathrm{SO}_{2}$, opacity, and select radionuclides is not uncommon during such testing. Key sampling techniques used in this type of testing are described below. These techniques produce an integrated sample over the test period, but usually do not produce real-time results. Estimated costs for a trial burn are not part of the scope of this document, but are assumed to be similar for each system. 
Organics--Two or more priricipal organic hazardous constituents (POHCs) are identified before the trial burn under the RCRA program. Greater than 99.99 percent ( 99.9999 percent for PCBs and or dioxins) DREs must be demonstrated on the POHCs. Emissions of organic products of incomplete combustion (PICs) will also have to be measured during the trial burn under both RCRA and TSCA programs. Typically, two organic sampling trains, one for volatile organics (the volatile organic sampling train or VOST) and one for semivolatile organics (the Modified Method 5 or MM-5 sampling train) are used to quantify organic emissions. Analytical turnaround can be as short as 1 or 2 days, respectively; however, standard analytical report turnaround is three weeks.

Metals--A variation of EPA Method 5, described in 40 CFR 266, Appendix IX, is used to collect samples to characterize stack gas emissions for metals. This train is configured to capture all RCRAregulated metals, including arsenic, barium, beryllium, cadmium, chromium (nonhexavalent or hexavalent), lead, mercury, nickel, silver, selenium, silver, and thallium. Laboratory analysis can be obtained within two days, but typically requires two to three weeks.

Acid Gases-- $\mathrm{HCl}$ and $\mathrm{Cl}_{2}$ are sampled using an EPA Method 0050 sampling train. In this train, a sample is collected isokinetically. The sample is drawn through a series of impingers used to scrub the acid gases. $\mathrm{HCl}$ is collected in the front impingers, which contain a sulfuric acid solution, and $\mathrm{Cl}_{2}$ is collected in the back impingers, which contain a sodium hydroxide solution. Each portion of the train is analyzed separately. With modifications, other acid gases may be analyzed on the same train.

Particulate Matter--Particulate matter is sampled using an EPA Method 5 sampling train, as described in 40 CFR Part 60, Appendix A. This sampling train includes a probe, filter, impingers, flow metering, and a vacuum system. Particulate is determined gravimetrically.

Radionuclides--Radiologica] monitoring requirements apply to all effluent release points with a potential to discharge radionuclides into the air in concentrations that will result in an effective dose equivalent (EDE) in excess of 0.1 mrem per year to a member of the public. For those discharge points resulting in $<0.1$ mrem per year, periodic monitoring is required to verify that emissions remain below 0.1 mrem per year. If more than one radionuclide is discharged, those radionuclides that could contribute 10 percent or more to the EDE must be measured. Gaseous radionuclides include tritium, iodine, noble gases, and a group identified as oxygen, nitrogen, carbon, and radon.

\subsection{Characterization of Final Waste Form}

Waste must be characterized after treatment to verify that the final waste form complies with regulatory requirements, shipping requirements, and the receiving facility WAC. These requirements include the Toxic Characteristic Leaching Procedure (TCLP) to determine if the waste exhibits a RCRA toxicity characteristics; total analyses to determine that the waste meets the RCRA LDR; the WIPP WAC for TRU-contaminated waste $(>100 \mathrm{nCi} / \mathrm{g}$ and $<200 \mathrm{~g}$ total); and low-level radioactive disposal site WAC for low-level waste.

Concentrations of leachable metals and organic contaminants in the final waste form must be shown to be less than TCLP regulatory levels. It is assumed that incinerated waste will not be ignitable, corrosive, or reactive, so these properties need not be tested. Waste passing TCLP (40 CFR Part 261, Subpart C) and not RCRA listed (40 CFR Part 261, Subpart D) does not require a disposal facility permitted to 
accept hazardous waste under the RCRA. However, such waste may not be land-disposed unless it meets LDR standards for Underlying Hazardous Constituents. This strict standard meets or exceeds most other LDR standards that are not dependent on specified technologies. Therefore, costs are evaluated based upon disposal in a RCRA disposal facility.

The WIPP WAC has been chosen as a standard because it is the only WAC existing for alpha-mixed waste. It is certain that whatever facility receives the waste for disposal, knowledge of the isotopic content of the waste form will be required. Section 5 of this document describes the WIPP WAC requirements.

2.6.1 Final Waste Form Assumptions. The following assumptions have been made concerning the volume of treated waste:

1. All ash fails TCLP

2. Treated ash will be stabilized in drums

3. Treatment of debris will not result in volume reduction due to stabilization requirements. Seven hundred drums of debris entering the treatment process will result in seven hundred drums of treated debris. Stabilization will occupy the interstitial spaces (based on cementation process).

4. Incineration and cementing of sludges will not result in volume reduction. While actual volume reduction may be achieved in some cases, cementitious waste form will offset these gains. The grout added to the ash for stabilization will also result in an increased waste volume. Three hundred drums of sludge waste are expected to produce three hundred drums of stabilized ash.

5. Ten percent of the stabilized ash waste drums will be sampled, for a total of one hundred drums. This is consistent with current end product sampling requirement under the RCRA.

6. All waste product drums will be subject to radiography to verify solidification of the final waste form.

2.6.2 Sampling and Analysis Costs. Costs for sampling and analysis have been estimated for individual samples requiring analysis in a glove box and are presented in Table 2-4. These costs are based on INEEL costs currently incurred to characterize TRU waste for the WIPP facility under the current WIPP WAC. Table 2-5 presents costs to characterize for disposal in a RCRA Subtitle C facility. 
Table 2-4 Costs for final waste form characierization for disposal at WIPP

\begin{tabular}{|l|r|c|c|c|c|r|r|}
\hline \multicolumn{1}{|c|}{ Analysis } & Unit cost & $\begin{array}{c}\text { Fraction of } \\
\text { drums } \\
\text { analyzed }\end{array}$ & Basis & $\begin{array}{c}\text { Basis } \\
\text { Factor }\end{array}$ & $\begin{array}{c}\text { Rounded } \\
\text { Number of } \\
\text { Drums }\end{array}$ & $\begin{array}{c}\text { Cost for } \\
1,000 \text { Drums }\end{array}$ & $\begin{array}{c}\text { Rounded to } \\
\text { nearest 1000 }\end{array}$ \\
\hline Venting \& Headspace VOCs \& $\mathrm{H}_{2}$ & $\$ 80$ & 1 & All & 1 & 1000 & $\$ 80,000$ & $\$ 80,000$ \\
\hline Headspace QC (VOCs \& $\mathrm{H}_{2}$ ) & $\$ 1,100$ & 0.0125 & All & 1 & 13 & $\$ 14,300$ & $\$ 14,000$ \\
\hline Radiography & $\$ 44$ & 1 & All & 1 & 1000 & $\$ 44,000$ & $\$ 44,000$ \\
\hline Passive-Active Neutron & $\$ 44$ & 1 & All & 1 & 1000 & $\$ 44,000$ & $\$ 44,000$ \\
\hline Gamma Spectrometry & $\$ 198$ & 0.1 & All & 1 & 100 & $\$ 10,800$ & $\$ 20,000$ \\
\hline Data Validation & $\$ 64$ & 1 & All & 1 & 1000 & $\$ 64,000$ & $\$ 64,000$ \\
\hline Visual Inspection & $\$ 12,000$ & 0.1 & Debris & 0.7 & 70 & $\$ 840,000$ & $\$ 840,000$ \\
\hline Sample Coring & $\$ 12,000$ & 0.1 & All Sludge & 0.3 & 30 & $\$ 360,000$ & $\$ 360,000$ \\
\hline Chemistry Suite & $\$ 4,600$ & 0.1 & Inorganic Sludge & 0.24 & 24 & $\$ 110,400$ & $\$ 110,000$ \\
\hline Chemistry Suite + PCBs & $\$ 6,350$ & 0.1 & Organic Sludge & 0.06 & 6 & $\$ 38,100$ & $\$ 38,000$ \\
\hline Detailed Debris Validation & $\$ 700$ & 0.1 & Debris & 0.7 & 70 & $\$ 49,000$ & $\$ 49,000$ \\
\hline Detailed sludge Validation & $\$ 900$ & 0.1 & Sludge & 0.3 & 30 & $\$ 27,000$ & $\$ 27,000$ \\
\hline Production Validation & $\$ 72$ & 0.9 & All & 1 & 900 & $\$ 64,800$ & $\$ 65,000$ \\
\hline Total & & & & & & $\$ 1,755,400$ & $\$ 1,755,000$ \\
\hline
\end{tabular}


Table 2-5 Cost for final waste form characterization for subtitle $C$ disposal - based on 1,000 containers input - base case

\begin{tabular}{|l|r|r|r|r|r|r|}
\hline \multicolumn{1}{|c|}{ Task/Test } & Cost each & $\begin{array}{c}\text { Fraction } \\
\text { Analyzed }\end{array}$ & $\begin{array}{r}\text { Final No. } \\
\text { of Drums }\end{array}$ & $\begin{array}{c}\text { Number of } \\
\text { Analyses }\end{array}$ & \multicolumn{1}{c|}{ Total Cost } & \multicolumn{1}{|c|}{$\begin{array}{c}\text { Total Cost to } \\
\text { Nearest } \\
\$ 1,000\end{array}$} \\
\hline Take samples & $\$ 12,000$ & 0.1 & 1000 & 100 & $\$ 1,200,000$ & $\$ 1,200,000$ \\
\hline alpha, beta, gamma & $\$ 1,014$ & 0.1 & 1000 & 100 & $\$ 101,400$ & $\$ 101,000$ \\
\hline Organics & $\$ 47$ & 0.1 & 1000 & 100 & $\$ 4,700$ & 5,000 \\
\hline Metals & $\$ 366$ & 0.1 & 1000 & 100 & $\$ 36,600$ & 37,000 \\
\hline Radiography & $\$ 44$ & 1.0 & 1000 & 1000 & $\$ 44,000$ & $\$ 44,000$ \\
\hline PAN/gamma & $\$ 242$ & 1.0 & 1000 & 1000 & $\$ 242,000$ & $\$ 242,000$ \\
\hline UHC/UTS list metals & $\$ 340$ & 0.1 & 1000 & 100 & $\$ 34,000$ & $\$ 34,000$ \\
\hline Total & & & & & $\$ 1,662,700$ & $\$ 1,663,000$ \\
\hline
\end{tabular}




\subsection{Thermal Treatment Base Case Cost Summary}

Characterization and monitoring costs for the base case rotary kiln incinerator can be summarized into the following categories: 1) front-end characterization; 2) process monitoring and off gas controls, 3) continuous monitoring and 4) final waste form characterization. These costs are summarized in Table 2 6. This table reflects costs for disposal at WIPP. Costs for disposal at a Subtitle C facility would be slightly lower.

Table 2-6 'Total estimated characterization and monitoring cost for 1,000 drums input - thermal base case

\begin{tabular}{|l|r|}
\hline & $\begin{array}{r}\text { Operating Cost Estimated to } \\
\text { Nearest \$1,000 for disposal in } \\
\text { WIPP }\end{array}$ \\
\hline Front-End Characterization (10\% verification) & $\$ 2,387,000$ \\
\hline Process Controls & $\$ 56,000$ \\
\hline Off gas Monitoring and Analysis & $\$ 108,000$ \\
\hline Characterization of the Final Waste form & $\$ 1,755,000$ \\
\hline Total & $\$ 4,306,000$ \\
\hline
\end{tabular}

\subsubsection{Front-End Characterization}

The estimated costs incurred through front-end characterization activities based on sampling 10 percent of the incoming wastes are $\$ 2,387,000$. Following the characterization and treatment of the initial 1,000 drums of waste, sampling may be further reduced. However, this is based on successfully demonstrating that waste streams are characterized to meet operational parameters for treatment. Reduced sampling requirements for front-end characterization are also dependent on the capacity of the treatment system to safely operate within its desiggn parameters, control air and emissions within design limits, and produce the desired final waste form.

\subsubsection{Process Monitoring}

Process monitoring costs, given the small number of parameters monitored for, tend to be small relative to other characterization and :nonitoring costs. Key criticality monitoring activities cost an estimated $\$ 56,000$.

\subsubsection{Off gas Monitoring arıd Analysis}

Trial burn off gas monitoring and analysis costs are not within the scope of this document. However, these costs are assumed to be similar between options. Estimated costs for routine off gas monitoring and analysis for the base case rotary kiln incinerator are tabulated in Table 2-3. The total operating cost per 1,000 drums (or one year of operation) is estimated to be $\$ 125,000$. 


\subsubsection{Final Waste Form Characterization}

Waste must be characterized after treatment to verify that the final waste form complies with regulatory requirements as well as the receiving facilities' WACs. Estimated costs for final waste form characterization were $\$ 1,755,000$ (Table 2-4) for disposal in WIPP and $\$ 1,663,000$ (Table 2-5) for disposal in a Subtitle $\mathrm{C}$ facility.

\subsubsection{Cost Analysis}

The cost of front-end characterization contributes the greatest portion of costs, even where 10 percent of the waste is assumed to be characterized. Much of this is attributable to the costs of actually conducting the intrusive sampling activity. Costs of final waste form characterization are somewhat higher for disposal in WIPP compared to a Subtitle $C$ facility. This difference in costs highlights the possibility that some of these WIPP requirements may be unnecessary when applied to treated waste (e.g., volatile organic analyses).

\subsection{Nonthermal Treatment}

A nonthermal treatment alternative was selected for comparison to the other approaches. The DOE is currently evaluating nonthermal treatment for some of its wastes. The treatment alternative described below was selected from the five system concepts analyzed in the Integrated Nonthermal Treatment System (INTS) Study "Biagi, et. al.," (1997). The system selected uses decontamination for most metals, macroencapsulation for inherently hazardous metals; vacuum desorption for soil, inorganic sludges and all debris; and catalytic wet oxidation (CWO) for destruction of organics in organic sludges.

Waste stream composition assumptions made for this alternative are as follows:

- Waste feed characterization must address each waste component, metals, other debris, and sludge. The drums of combined metals, debris, and sludge must be physically sorted and segregated in an enclosed environment. This sorting process will result in three waste streams: sludge and debris for thermal desorption, followed by CWO, and decontamination for metals and macroencapsulation for inherently hazardous metals.

- Based on INEEL alpha waste composition, 700 of the 1,000 drums of waste are debris. Sorting of debris waste will result in 21 drums of metal waste for decontamination, four drums of inherently hazardous metal for macroencapsulation, and 675 drums of debris for thermal desorption followed by CWO of the organics. The waste to be decontaminated or macroencapsulated will undergo NDA/PAN prior to treatment. Ten percent (68) of the 675 drums of debris must be analyzed for hazardous characteristics and operational constraints prior to thermal desorption. This sampling can take place during the sort and segregate process, and will consist of three samples from each debris drum (204 samples).

- 300 of the 1,000 drums of waste contain sludge. 80 percent ( 240 drums) contain inorganics and will be characterized prior to thermal desorption. 20 percent ( 60 drums) contain organics and will go through CWO. Sludge is assumed to have no free liquids, therefore, no corrosivity tests are run on sludges. Samples of sludge going to CWO can be taken during sorting and 
segregating. CWO results in 48 drums of treated waste. These 48 drums must be characterized for PCB's prior to stibilization to confirm that TSCA disposal requirements have been achieved.

Treated wastes whicl go through a grouting process before disposal include the products from CWO, decontaminat on and thermal desorption. These wastes undergo NDA/PAN, (except for products of thermal desorption for which radioactivity concentrations are not expected to change on a per drum basis), VOCs/total SVOCs and total metal analysis. In most cases, VOCs/SVOCs are conducted insteal of TOC due to the presence of wood waste.

\subsubsection{System Description}

The nonthermal treatment system consists of a treatment train, with each component of the train addressing different portions of the input waste and requiring different characterization prior to treatment. Gaseous treatment products are assumed to be treated through a base case off gas-type system modified to eliminate thermal oxidations. Aqueous treatment products will be further treated in a photo oxidation unit producing a wastewater suitable for discharge under a National Pollutant Discharge Elimination System (NPDES) permit. Figure 2-2 provides a conceptual flowchart of the nonthermal treatment process.

2.8.1.1 Organic Destruction. CWO would be used to destroy organics. CWO uses an iron oxidant in a catalyzed solution to accomplish destruction in a reactor that agitates the solution to enhance the oxidation reaction. Off gas (primarily water vapor, $\mathrm{CO}_{2}, \mathrm{O}_{2}$, and acid gases) is condensed and a portion is recycled as reagent. The remaining acid is neutralized and treated as aqueous waste. Periodically, metals are precipitated from the reactor solution when the concentration of dissolved metals, including radionuclides, reaches concentrations that affect the acid concentration. The filtrate is treated as aqueous waste and the metal precipitates are stabilized.

2.8.1.2 Vacuum Desorption. This process is used for process residues, inorganic sludges, soil, and debris. The waste is size-reduced to particles less than one inch in diameter and then processed through a vacuum dryer operated in a batch mode. This vacuum dryer separates organic contaminants from inert solids by heating nitrogen cover gas to desorb the organic components and by indirectly heating the waste in a partial vacuum. Desorber off gas is condensed and routed for aqueous waste treatment (for aqueous streams) or amalganiation (for elemental mercury) or CWO (for organics) or to the off gas treatment subsystem.

2.8.1.3 Decontamination. lead and metals are decontaminated using a water blasting method. Excess liquid is sent to aqueous trealment and the contaminated grit is treated as process residues using the vacuum desorption unit.

2.8.1.4 Photo-Oxidation. A.queous waste is treated in a flexible system using photo-oxidation to destroy dissolved organics. Suspended solids are filtered, and dissolved organics are removed and sent to the CWO. For the purposes of this study, treatment of large volumes of aqueous wastes is not anticipated in this system. 


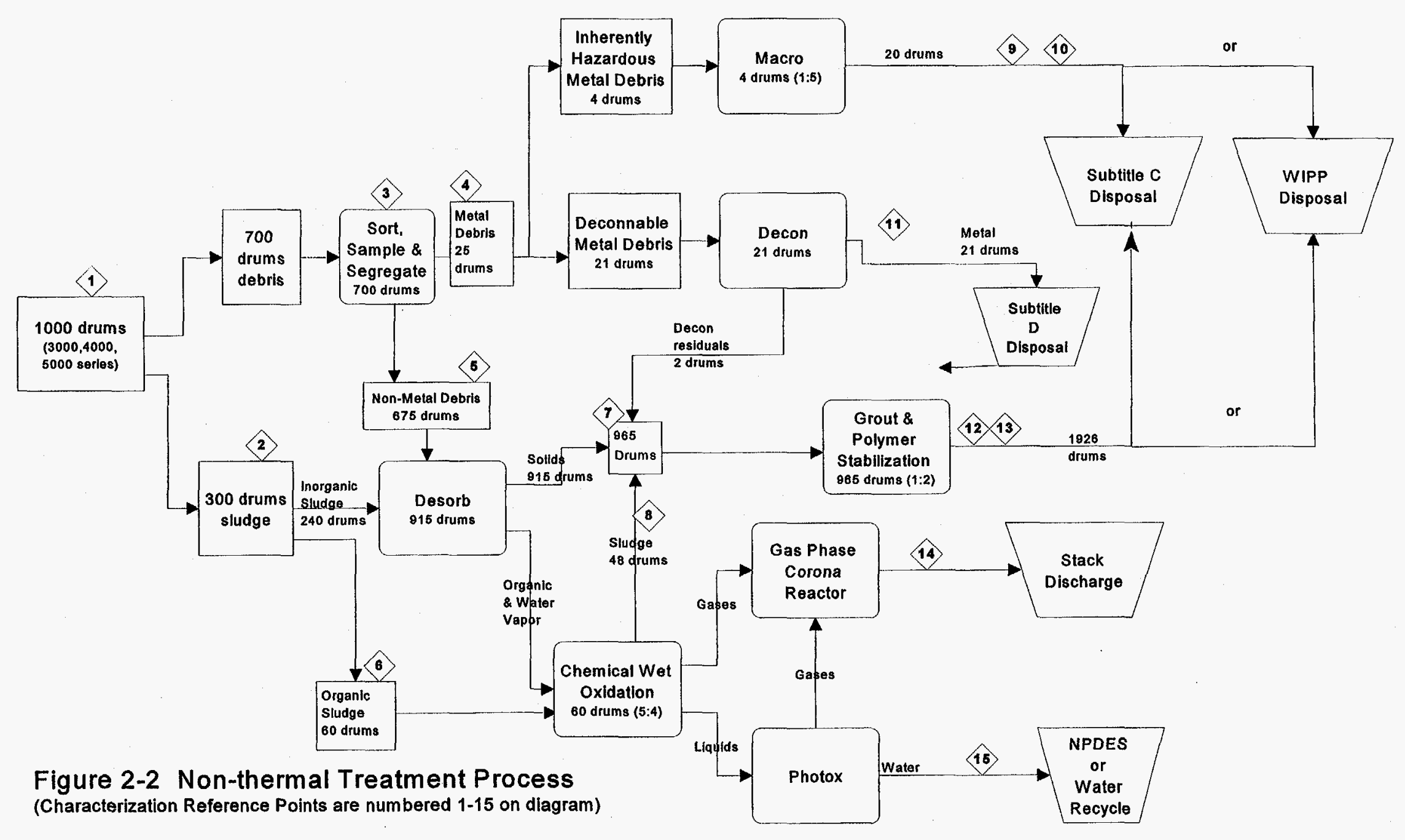


2.8.1.5 APC Device. The APC subsystem is composed of a baghouse, pre-filter, Gas Phase Corona Reactor (GPCR) unit, a wet gas scrubber, mist eliminator, activated carbon for trace organic removal, sulfur-impregnated activated carbon for mercury vapor removal, and CEMs. Gross particulates are removed by a HEPA filter. After particulate removal, the GPCR uses a strong electric field across a packed bed of dielectric particles, which creates a corona that causes the gas to be partially ionized and form a plasma in the voids between the particles. The electrons in the plasma cause organic contaminant destruction through direct interaction with the contaminant molecules. The treated gas is then passed through the acid gas scrubber: Off gas from all activities except decontamination and stabilization would be routed through this system.

2.8.1.6 Grout. This system blends grout with desorbed solids and other wastes so that the waste is stabilized, does not exhibit a toxicity characteristic, and meets the LDR treatment standards.

2.8.1.7 Macroencapsulation. This system involves treating a waste-form heretofore prohibited from land disposal. The polyethylene bonds to surfaces of the waste-form, fills voids between pieces of waste, and bonds to the inner surface of the container, thereby isolating the waste-form from possible dissolution substances. At the end of treatment, the waste will be ready for disposal.

\subsubsection{Front End Characterization}

Table 2-7 provides costs for front end characterization of wastes for nonthermal treatment. These costs are substantially higher than costs for front end characterization for thermal treatment due to two factors: the requirement to open and sort each drum to allow appropriate treatment, and number of separate steps which can involve repeated sampling and analysis.

\subsubsection{Process Monitoring}

Extensive sorting required to achieve treatment of alpha-mixed waste will serve to minimize criticality concerns in the nonthermal treatment process. Operators will have better knowledge of the waste being treated, the potential for unknowns is reduced, and the need to 'over-engineer' to address potential criticality issues is minimized.

Because front-end characterization and sorting is extensive, it is assumed that criticality monitoring costs will be similar to the costs for operating the base case thermal system. Based on costs for the base case thermal system, costs for criticality monitoring of a non-thermal system would total $\$ 56,000$.

\subsubsection{Continuous Monitoririg}

Costs for continuous monitoring are assumed to be equivalent to costs of the continuous monitoring thermal treatment. It is assumed that monitoring requirements for a non-thermal unit would be no less stringent than as those for a thermal unit.

\subsubsection{Final Waste Form}

Waste products from nonthennal treatment fall into five categories: off gas, wastewater, solids remaining after critical water oxidation, decontaminated metal, and macroencapsulated metal. The off gas system is assumed to be the same as the base case and is not addressed in this section. 
The ultimate products of CWO are solid residues of treated sludge and debris. It is assumed that volume reduction of 20 percent occurs due to volatilization and destruction of organic materials. The remaining waste must be stabilized and characterized to determine compliance with the WIPP WAC. The products of thermal desorption must also be stabilized and characterized for compliance with the WIPP WAC. For purposes of this report it is assumed that the stabilization process doubles the waste volume.

Metal waste that has been decontaminated must be monitored for both radiological contamination, LDR standards, and PCBs. The goal is that such metal may be recycled as 'clean' or disposed as low-level radioactive waste. The LDR criteria of a visual confirmation of a 'clean surface' may be applied to debris (40 CFR Part 268.45). However, because this determination of a 'clean surface' is less stringent than the decontamination requirements for PCBs under 40 CFR Part 761, the more stringent requirements must apply to the debris for this report.

Both critical water oxidation/photochemical oxidation and metal decontamination result in contaminated wastewater. Radiological and chemical contamination are expected to be present. In most areas of the country, this water might be discharged to "waters of the United States" under an NPDES permit. Characterization requirements for this "final waste form" are based on this assumption and reflect basic NPDES requirements. Additional requirements may be applied in an actual permit. Because these processes are expected to be operated in a batch mode rather than continuously, the discharge of wastewater is also assumed to be intermittent.

Inherently hazardous metals that are macroencapsulated have met the technology standard specified by the LDR (40 CFR 268.45). They must be disposed in a RCRA Subtitle C facility that also possesses a U.S. Nuclear Regulatory Commission (NRC) license. The primary limitation for current disposal facilities will be the radionuclide content, and/or radionuclide activity levels found in this waste.

Assumptions for waste product characterization follow:

1. Stabilization of wastes will result in 1930 drums ready for RCRA or subtitle C disposal. Ten percent (193) of these drums will be sampled and analyzed for WIPP WAC requirements. 100 percent will undergo PAN and gamma spectroscopy.

2. Each drum of decontaminated metal debris will receive a composite smear sample for PCBs. Each drum will be measured by gamma spectrometry. Decontaminated metal will not require glove box or hot cell techniques for chemical analysis.

3. Discharge of wastewater under an NPDES permit will occur weekly, after sampling and analysis. Fifty samples per year will be taken. The samples may contain low levels of radionuclides, but may be analyzed using standard laboratory techniques and not require a glove box or hot cell.

Estimates costs of characterization for disposal in WIPP based on current WIPP WAC are shown in Table 2-8. Estimates costs of characterization for disposal in a Subtitle $\mathrm{C}$ facility are shown in Table 2-9.. 
Table 2-7 Nonthermal front-end characterization

\begin{tabular}{|c|c|c|c|c|c|c|c|c|c|c|c|c|}
\hline $\begin{array}{l}\text { Figure } \\
2-2 \\
\text { Key }\end{array}$ & Task/Analysis & Method & $\begin{array}{c}\text { Fraction } \\
\text { of drums } \\
\text { analyzed }\end{array}$ & $\begin{array}{l}\text { No. of } \\
\text { "other" } \\
\text { drums }\end{array}$ & $\begin{array}{c}\text { No. of } \\
\text { analyses/ } \\
\text { "other" } \\
\text { drums }\end{array}$ & $\begin{array}{l}\text { No. of } \\
\text { sludge } \\
\text { drums }\end{array}$ & $\begin{array}{c}\begin{array}{c}\text { No. of } \\
\text { analyses } \\
\text { per sludge } \\
\text { drum }\end{array} \\
\end{array}$ & $\begin{array}{l}\text { No. of } \\
\text { debris } \\
\text { drums }\end{array}$ & $\begin{array}{c}\text { No. of } \\
\text { analyses } \\
\text { per/debris } \\
\text { drum }\end{array}$ & $\begin{array}{c}\text { Total } \\
\text { No. of } \\
\text { drums/ } \\
\text { analyses }\end{array}$ & $\begin{array}{c}\text { Sampling } \\
\text { Analysis } \\
\text { cost/each }\end{array}$ & $\begin{array}{l}\text { Sampling/ } \\
\text { Analysis } \\
\text { Cost }\end{array}$ \\
\hline \multirow[t]{4}{*}{1} & All Sludge and debris & & & & & 300 & & 700 & & & & \\
\hline & NDA (gamma) & Lab SOPs & 1 & & & 300 & 1 & 700 & 1 & 1,000 & $\$ 198$ & $\$ 198,000$ \\
\hline & NDA (PAN) & Lab SOPs & 1 & & & 300 & 1 & 700 & 1 & 1,000 & $\$ 44$ & $\$ 44,000$ \\
\hline & Radiography & Lab SOPs & 1 & & & 300 & 1 & 700 & 1 & 1,000 & $\$ 44$ & $\$ 44,000$ \\
\hline 3 & $\begin{array}{l}\text { Sort/Segregate/Visual } \\
\text { Inspection/Sample (debris only) }\end{array}$ & $\begin{array}{l}\text { Manual/Sampling \& } \\
\text { Analysis Plans (SAP) }\end{array}$ & 1 & & & & & 700 & 1 & 700 & $\$ 12,000$ & $\$ 8,400,000$ \\
\hline \multirow[t]{3}{*}{4} & Inher. Haz. Metals to Macro & & & & & & & 4 & & 0 & & \\
\hline & NDA (gamma) & Lab SOPs & 1 & & & & & 4 & 1 & 4 & $\$ 198$ & $\$ 1,000$ \\
\hline & NDA (PAN) & Lab SOPs & 1 & & & & & 4 & 1 & 4 & $\$ 44$ & $\$ 0$ \\
\hline \multirow[t]{3}{*}{4} & Metals to Decon & & & & & & & 21 & & 0 & & \\
\hline & NDA (gamma) & Lab SOPs & 1 & & & & & 21 & 1 & 21 & $\$ 198$ & $\$ 4,000$ \\
\hline & NDA (PAN) & Lab SOPs & 1 & & & & & 21 & 1 & 21 & $\$ 44$ & $\$ 1,000$ \\
\hline \multirow[t]{8}{*}{2,5} & Sludge and Debris to TD & & & & & 240 & & 675 & & & & \\
\hline & NDA (gamma) (debris only) & Lab SOPs & 1 & & & 0 & 0 & 675 & 1 & 675 & $\$ 198$ & $\$ 134,000$ \\
\hline & NDA (PAN) (debris only) & Lab SOPs & 1 & & & 0 & 0 & 675 & 1 & 675 & $\$ 44$ & $\$ 30,000$ \\
\hline & Take samples (sludge only) & SA P & 0.1 & & & 24 & 1 & 0 & 0 & 24 & $\$ 12,000$ & $\$ 288,000$ \\
\hline & Ignitability & SW $846-1010$ & 0.1 & & & 24 & 1 & 68 & 3 & 227 & $\$ 100$ & $\$ 23,000$ \\
\hline & Reactivity & SW 846 - II 7.3 & 0.1 & & & 24 & 1 & 68 & 3 & 227 & $\$ 2,700$ & $\$ 613,000$ \\
\hline & Organics & SW $846-8000$ series & 0.1 & & & 24 & 1 & 68 & 3 & 227 & $\$ 1,021$ & $\$ 231,000$ \\
\hline & Metals & SW $846-6010 \& 7470$ & 0.1 & & & 24 & 1 & 68 & 3 & 227 & $\$ 366$ & $\$ 83,000$ \\
\hline \multirow[t]{3}{*}{6} & $\begin{array}{l}\text { Sludge to CWO (assume no free } \\
\text { liquids) }\end{array}$ & & & & & 60 & & & & & & \\
\hline & Ignitability & SW $846-1010$ & 0.1 & & & 6 & 1 & 0 & 0 & 6 & $\$ 100$ & $\$ 1,000$ \\
\hline & Reactivity & SW 846 - II 7.3 & 0.1 & & & 6 & 1 & 0 & 0 & 6 & $\$ 2,700$ & $\$ 16,000$ \\
\hline
\end{tabular}


Table 2-7 Nonthermal front-end characterization (contd.)

\begin{tabular}{|c|c|c|c|c|c|c|c|c|c|c|c|c|}
\hline $\begin{array}{l}\text { Figure } \\
2-2 \\
\text { Key }\end{array}$ & Task/Analysis & Method & $\begin{array}{c}\text { Fraction } \\
\text { of drums } \\
\text { analyzed }\end{array}$ & $\begin{array}{l}\text { No. of } \\
\text { "other" } \\
\text { drums }\end{array}$ & $\begin{array}{l}\text { No. of } \\
\text { analyses/ } \\
\text { "other" } \\
\text { drums }\end{array}$ & $\begin{array}{l}\text { No. of } \\
\text { sludge } \\
\text { drums }\end{array}$ & $\begin{array}{c}\begin{array}{c}\text { No. of } \\
\text { analyses } \\
\text { per sludge } \\
\text { drum }\end{array} \\
\end{array}$ & $\begin{array}{l}\text { No. of } \\
\text { debris } \\
\text { drums }\end{array}$ & $\begin{array}{c}\text { No. of } \\
\text { analyses } \\
\text { per/debris } \\
\text { drum } \\
\end{array}$ & $\begin{array}{c}\text { Total } \\
\text { No. of } \\
\text { drums/ } \\
\text { analyses }\end{array}$ & $\mid \begin{array}{c}\text { Sampling/ } \\
\text { Analysis } \\
\text { cost/each }\end{array}$ & $\begin{array}{c}\text { Sampling/ } \\
\text { Analysis } \\
\text { Cost }\end{array}$ \\
\hline & Metals & SW $846-6010 \& 7470$ & 0.1 & & & 6 & 1 & 0 & 0 & 6 & $\$ 366$ & $\$ 2,000$ \\
\hline & PCBs & SW $846-8080$ or 8081 & 0.1 & & & 6 & 1 & 0 & 0 & 6 & $\$ 275$ & $\$ 2,000$ \\
\hline & TOC & 9060 or $-5310-\mathrm{B}, \mathrm{C}$ or $\mathrm{D}$ & 0.1 & & & 6 & 1 & 0 & & 6 & $\$ 47$ & $\$ 0$ \\
\hline & Ash & ASTM D3174-89 & 0.1 & 0 & 0 & 6 & 1 & 0 & 0 & 6 & $\$ 405$ & $\$ 2,000$ \\
\hline & Btu & ASTM D3286-91a & 0.1 & 0 & 0 & 6 & 1 & 0 & 0 & 6 & $\$ 3,240$ & $\$ 19,000$ \\
\hline & $\begin{array}{l}\mathrm{Cl} \text { and } \mathrm{F} \text { (for off gas emissions } \\
\text { estimate) }\end{array}$ & SW $846-9056$ & 0.1 & 0 & 0 & 6 & 1 & 0 & 0 & 6 & $\$ 450$ & $\$ 3,000$ \\
\hline \multirow[t]{7}{*}{8} & Sludge from CWO to grout & & & 48 & & & & & & 0 & & \\
\hline & NDA(gamma) & Lab SOPs & 1 & 48 & & & & & & 48 & $\$ 198$ & $\$ 10,000$ \\
\hline & NDA(Pan) & Lab SOPs & 1 & 48 & & & & & & 48 & $\$ 44$ & $\$ 2,000$ \\
\hline & Take samples & SAP & 0.1 & 5 & 1 & 0 & 0 & 0 & 0 & 5 & $\$ 12,000$ & $\$ 60,000$ \\
\hline & TOC & 9060 or $-5310-\mathrm{B}, \mathrm{C}$ or $\mathrm{D}$ & 0.1 & 5 & 1 & 0 & 0 & 0 & 0 & 5 & $\$ 47$ & $\$ 0$ \\
\hline & PCBs & SW $846-8080$ or 8081 & 0.1 & 5 & & & & & & 5 & $\$ 275$ & $\$ 1,000$ \\
\hline & Total metals & SW $846-6010 \& 7470$ & 0.1 & 5 & 1 & 0 & 0 & 0 & 0 & 5 & $\$ 366$ & $\$ 2,000$ \\
\hline \multirow[t]{6}{*}{7} & Decon residuals to Grout & & & 5 & & & & & & & & \\
\hline & NDA (gamma) & Lab SOPs & 1 & 2 & & & & & & 2 & $\$ 198$ & 0 \\
\hline & NDA (PAN) & Lab SOPs & 1 & 2 & & & & & & 2 & $\$ 44$ & 0 \\
\hline & Take samples & & 1 & 2 & 1 & & & & & 2 & $\$ 12,000$ & $\$ 24,000$ \\
\hline & VOCs/total SVOAs & SW $846-8260 A \& 8270 \mathrm{~B}$ & 1 & 2 & 1 & & & & & 2 & $\$ 645$ & $\$ 1,000$ \\
\hline & Total metals & SW $846-6010 \& 7470$ & 1 & 2 & 1 & & & & & 2 & $\$ 150$ & $\$ 0$ \\
\hline \multirow[t]{5}{*}{7} & TD solid product to grout & & & 915 & & & & & & 0 & & $\$ 0$ \\
\hline & Take samples & SAP & 0.2 & 183 & 1 & & & & & 183 & $\$ 12,000$ & $\$ 2,196,000$ \\
\hline & VOCs/total SVOAs & SAP & 0.2 & 183 & 1 & & & & & 183 & $\$ 645$ & $\$ 118,000$ \\
\hline & Total metals & SW $846-6010 \& 7470$ & 0.2 & 183 & 1 & & & & & 183 & $\$ 366$ & $\$ 67,000$ \\
\hline & Total & & & & & & & & & & & $\$ 12,626,000$ \\
\hline
\end{tabular}


Table 2-8 Nonthermal final waste form characterization for disposal in WIPP

\begin{tabular}{|c|c|c|c|c|c|c|c|}
\hline $\begin{array}{c}\text { Figure } \\
2-2 \\
\text { Key }\end{array}$ & Task/Analysis & $\begin{array}{l}\text { Fraction } \\
\text { of drums } \\
\text { analyzed }\end{array}$ & $\begin{array}{l}\text { No. of } \\
\text { "other" } \\
\text { drums }\end{array}$ & $\begin{array}{c}\text { No. of } \\
\text { analyses/ } \\
\text { other drums }\end{array}$ & $\begin{array}{l}\text { Total No. } \\
\text { of drums/ } \\
\text { analyses }\end{array}$ & $\begin{array}{c}\text { Sampling/ } \\
\text { Analysis } \\
\text { cost/each }\end{array}$ & $\begin{array}{c}\text { Sampling/ } \\
\text { Analysis } \\
\text { Cost }\end{array}$ \\
\hline \multirow[t]{8}{*}{9,10} & Macro to WIPP (debris only) & & 20 & & & & \\
\hline & Venting \& Headspace VOC & 1 & 20 & 1 & 20 & $\$ 80$ & $\$ 2,000$ \\
\hline & Headspace Q.C (VOCs and H2) & 0.0125 & 20 & 1 & 1 & $\$ 1,100$ & $\$ 1,000$ \\
\hline & visual & 0.1 & 2 & 2 & 2 & $\$ 12,000$ & $\$ 24,000$ \\
\hline & NDA (gamma) & 1 & 20 & 20 & 20 & $\$ 198$ & $\$ 4,000$ \\
\hline & NDA (PAN) & 1 & 20 & 20 & 20 & $\$ 44$ & $\$ 1,000$ \\
\hline & radiography & 1 & 20 & 20 & 20 & $\$ 44$ & $\$ 1,000$ \\
\hline & Detailed debris validation & 0.1 & 20 & 2 & 2 & $\$ 700$ & $\$ 1,000$ \\
\hline \multirow[t]{4}{*}{11} & Deconned Metal to Subtitle D & & 21 & & & & \\
\hline & visual & 1 & 21 & 1 & 21 & $\$ 25$ & $\$ 1,000$ \\
\hline & NDA (gamma) & 1 & 21 & 1 & 21 & $\$ 44$ & $\$ 1,000$ \\
\hline & NDA (PAN) & 1 & 21 & 1 & 21 & $\$ 44$ & $\$ 1,000$ \\
\hline \multirow[t]{10}{*}{12,13} & Grouted Product to XIPP & & 1926 & & & & \\
\hline & Venting \& Headspace VOC & 1 & 1926 & 1 & 1,926 & $\$ 80$ & $\$ 154,000$ \\
\hline & Headspace Q.C (VOCs and H2) & 0.0125 & 1926 & 24 & 24 & $\$ 1,100$ & $\$ 26,000$ \\
\hline & visual/ sample coring & 0.1 & 1926 & 193 & 193 & $\$ 12,000$ & $\$ 2,316,000$ \\
\hline & NDA (gamma) & 1 & 1926 & 1 & 1,926 & $\$ 198$ & $\$ 381,000$ \\
\hline & NDA (PAN) & 1 & 1926 & 1 & 1,926 & $\$ 44$ & $\$ 85,000$ \\
\hline & Chemistry Suite & 0.024 & 46 & 1 & 46 & $\$ 4,600$ & $\$ 213,000$ \\
\hline & Chemistry Suite + PCB & 0.006 & 5 & & 5 & $\$ 6,350$ & $\$ 32,000$ \\
\hline & Detailed debris validation & 0.07 & 135 & & 135 & $\$ 700$ & $\$ 95,000$ \\
\hline & Detailed sludge validation & 0.03 & 51 & & 51 & $\$ 900$ & $\$ 46,000$ \\
\hline \multirow[t]{3}{*}{14} & Off gas from Corona lReactor* & & & & & & $\$ 10,000$ \\
\hline & THC CEM* & & & & & & $\$ 8,000$ \\
\hline & CO CEM* & & & & & & $\$ 8,000$ \\
\hline \multirow[t]{8}{*}{15} & $\begin{array}{l}\text { Water from Photox to NPDES } \\
\text { or recycle }\end{array}$ & & & & & & \\
\hline & Total metals & & & & 50 & $\$ 366$ & $\$ 18,000$ \\
\hline & Total organic carbon & & & & 50 & $\$ 47$ & $\$ 2,000$ \\
\hline & TDS & & & & 50 & $\$ 20$ & $\$ 1,000$ \\
\hline & TSS & & & & 50 & $\$ 20$ & $\$ 1,000$ \\
\hline & $\mathrm{pH}$ & & & & 50 & $\$ 10$ & $\$ 1,000$ \\
\hline & alpha, beta, gamma & & & & 50 & $\$ 250$ & $\$ 13,000$ \\
\hline & Total & & & & & & $\$ 3,447,000$ \\
\hline
\end{tabular}

* Costs are operating costs per year from Table 2-3. 
Table 2-9. Nonthermal final waste form characterization for disposal in Subtitle C Facility

\begin{tabular}{|c|c|c|c|c|c|c|c|}
\hline $\begin{array}{c}\text { Figure } \\
2-2 \\
\text { Key } \\
\end{array}$ & Task/Analysis & $\begin{array}{l}\text { Fraction } \\
\text { of drums } \\
\text { analyzed }\end{array}$ & $\begin{array}{l}\text { No. of } \\
\text { "other" } \\
\text { drums }\end{array}$ & $\begin{array}{c}\begin{array}{c}\text { No. of } \\
\text { analyses/ } \\
\text { other drums }\end{array} \\
\end{array}$ & $\begin{array}{l}\text { Total No. } \\
\text { of drums/ } \\
\text { analyses }\end{array}$ & $\begin{array}{c}\text { Sampling/ } \\
\text { analysis } \\
\text { cost/each }\end{array}$ & $\begin{array}{c}\text { Sampling/ } \\
\text { analysis } \\
\text { cost }\end{array}$ \\
\hline \multirow[t]{10}{*}{9,10} & Macro to Subtitle C & & 20 & & & & \\
\hline & Take samples & 0.1 & 2 & & 2 & $\$ 12,000$ & $\$ 24,000$ \\
\hline & alpha, beta, gamma & 0.1 & 2 & 1 & 2 & $\$ 1,014$ & $\$ 2,000$ \\
\hline & organics & 0.1 & 2 & 1 & 2 & $\$ 47$ & $\$ 0$ \\
\hline & radiography & 1 & 20 & & 20 & $\$ 44$ & $\$ 1,000$ \\
\hline & NDA (gamma) & 1 & 20 & 1 & 20 & $\$ 44$ & $\$ 1,000$ \\
\hline & NDA (PAN) & 1 & 20 & 1 & 20 & $\$ 44$ & $\$ 1,000$ \\
\hline & UHC/UTS & 0.1 & 2 & & 2 & $\$ 340$ & $\$ 1,000$ \\
\hline & metals & 0.1 & 2 & & 2 & $\$ 366$ & $\$ 1,000$ \\
\hline & PCBs & 0.1 & 2 & 1 & 2 & $\$ 275$ & $\$ 1,000$ \\
\hline \multirow[t]{4}{*}{11} & Deconned Metal to Subtitle D & & 21 & & & & \\
\hline & visual & 1 & 21 & 1 & 21 & $\$ 25$ & $\$ 1,000$ \\
\hline & NDA (gamma) & 1 & 21 & 1 & 21 & $\$ 44$ & $\$ 1,000$ \\
\hline & NDA (PAN) & 1 & 21 & 1 & 21 & $\$ 44$ & $\$ 1,000$ \\
\hline \multirow[t]{10}{*}{12,13} & Grouted Product to Subtitle C & & 1926 & & & & \\
\hline & Take samples & 0.1 & 193 & 1 & 193 & $\$ 12,000$ & $\$ 2,316,000$ \\
\hline & alpha, beta, gamma & 0.1 & 193 & 1 & 193 & $\$ 1,014$ & $\$ 196,000$ \\
\hline & organics & 0.1 & 193 & 1 & 193 & $\$ 47$ & $\$ 9,000$ \\
\hline & radiography & 1 & 1926 & & 1,926 & $\$ 44$ & $\$ 85,000$ \\
\hline & NDA (gamma) & 1 & 1926 & 1 & 1,926 & $\$ 198$ & $\$ 381,000$ \\
\hline & NDA (PAN) & 1 & 1926 & 1 & 1,926 & $\$ 44$ & $\$ 85,000$ \\
\hline & UHC/UTS & 0.1 & 193 & & 193 & $\$ 340$ & $\$ 66,000$ \\
\hline & METALS & 0.1 & 193 & & 193 & $\$ 366$ & $\$ 42,000$ \\
\hline & PCBs & 0.1 & 193 & 1 & 193 & $\$ 275$ & $\$ 53,000$ \\
\hline \multirow[t]{4}{*}{14} & Off gas from Corona Reactor* & & & & & & \\
\hline & THC CEM* & & & & & & $\$ 10,000$ \\
\hline & CO CEM* & & & & & & $\$ 8,000$ \\
\hline & $\mathrm{Cl} \mathrm{CEM}^{*}$ & & & & & & $\$ 8,000$ \\
\hline \multirow[t]{8}{*}{15} & Water from Photox to NPDES or recycle & & & & & & \\
\hline & Total metals & & & & 50 & $\$ 366$ & $\$ 18,000$ \\
\hline & Total organic carbon & & & & 50 & $\$ 47$ & $\$ 2,000$ \\
\hline & TDS & & & & 50 & $\$ 20$ & $\$ 1,000$ \\
\hline & TSS & & & & 50 & $\$ 20$ & $\$ 1,000$ \\
\hline & $\mathrm{pH}$ & & & & 50 & $\$ 10$ & $\$ 1,000$ \\
\hline & alpha, beta, gamma & & & & 50 & $\$ 250$ & $\$ 13,000$ \\
\hline & Total & & & & & & $\$ 3,330,000$ \\
\hline
\end{tabular}

* Costs are operating costs per year from Table 2-3. 


\subsection{Nonthermal Treatment System Alternative Cost Summary}

Characterization and monitoring costs for the nonthermal treatment system alternative can be summarized in the following categories: 1) front-end characterization, 2) process controls, 3) off gas monitoring and analysis, and 4) final waste form characterization. Table 2-10 provides a summary of the nonthermal treatment system.

\subsubsection{Front-End Characterization}

General assumptions for the nonthermal system are noted in Section 2.3. Estimated costs for front-end characterization of the incoming wastes are $\$ 16,326,000$ (Table 2-7).

\subsubsection{Process Controls}

Process control costs, given the small number of parameters monitored for, tend to be small relative to other characterization and monitoring costs. Process control costs are therefore, considered the same as for the base case thermal treatment (i.e. - $\$ 56,000$ ).

\subsubsection{Off gas Monitoring and Analysis}

Off gas monitoring and analysis costs typically include trial burn and testing costs. Costs associated with this type of activity are assumed to be similar between options and are therefore not considered. As noted, system requirements for routine off gas monitoring and analysis for the non-thermal treatment system are anticipated to be similar to the rotary kiln incinerator base case, and the costs are therefore estimated to be $\$ 125,000$ (Table 2-3).

\subsubsection{Final Waste Form Characterization}

Waste must be characterized after treatment to verify that the final waste form complies with regulatory requirements as well as the receiving facilities WAC. Estimated costs for final waste form characterization are $\$ 3,304,000$ for disposal in a Subtitle $C$ facility and $\$ 3,421,000$ for disposal at WIPP.

\subsubsection{Cost Comparison to Thermal Treatment}

Based on the costs provided above, the total estimated cost for the nonthermal system is shown in Table 2-10. These costs are substantially higher for front-end characterization for non-thermal treatment compared to thermal treatment. Considerably more costs are involved in sorting and taking samples. However, once sorting has bein accomplished, the number of analyses can be limited to those required for specific waste types. This table reflects costs of disposal at WIPP. Costs of disposal at a Subtitle C facility would be slightly lower. 
Table 2-10 Total estimated characterization, process control, and monitoring cost - nonthermal system

\begin{tabular}{|l|r|}
\hline \multicolumn{1}{|c|}{ Item } & $\begin{array}{r}\text { Annual Operating Costs Estimated to } \\
\text { the Nearest } \$ 1,000 \text { for disposal in } \\
\text { WTPP }\end{array}$ \\
\hline Front-end \& Final Waste Form Characterization & $\$ 12,626,000$ \\
\hline Process Controls & $\$ 56,000$ \\
\hline Off gas Monitoring and analysis & $\$ 125,000$ \\
\hline Final Waste Form & $\$ 3,421,000$ \\
\hline Total & $\$ 16,228,000$ \\
\hline
\end{tabular}




\section{Treatment Base Case Improvements/refinements}

This section addresses technologies, studies and new approaches that could address weaknesses in the base case or improvements to the base case. The section also discusses each of the four main areas where changes could take place: front-end characterization; process equipment and off gas controls; continuous monitoring; and final waste form characterization. For each area, potential changes along with an assessment of costs and limitations of the change are addressed.

\subsection{Front-End Characterization}

This section describes potential improvements to front-end characterization activities. Table 3-1 summarizes these improvements and associated costs.

Table 3-1 Potential front-end characterization improvements, 1000 drums

\begin{tabular}{|l|l|c|r|r|}
\hline \multicolumn{1}{|c|}{$\begin{array}{c}\text { Sampling } \\
\text { Activity }\end{array}$} & Alternative Approach & $\begin{array}{c}\text { Time to } \\
\text { Develop } \\
\text { Alternative } \\
\text { years } \\
\text { Metals }\end{array}$ & $\begin{array}{c}\text { Cost to } \\
\text { Develop } \\
\text { Alternative }\end{array}$ & $\begin{array}{r}\text { Cost to Run } \\
\text { Alternative } \\
\text { per year }\end{array}$ \\
\hline Chlorine & At-line NDA & 3 & $\$ 500,000^{*}$ & $\$ 33,000$ \\
\hline Btu & $\begin{array}{l}\text { At-line NDA } \\
\text { eliminate NDA or }\end{array}$ & 3 & $\$ 500,000 *$ & $\$ 33,000$ \\
\hline Ash Content & eliminate & N/A & $\$ 500,000 *$ & $\$ 33,000$ \\
\hline Isotopic assay & $\begin{array}{l}\text { Bulk assay/ statistical } \\
\text { approach }\end{array}$ & N/A & $\$ 0$ & $\$ 0$ \\
\hline Total & & & $\$ 6,500,000$ & $\$ 363,000$ \\
\hline
\end{tabular}

* costs for development of At line NDA total $\$ 500,000$

\subsubsection{Non-Radioactive Constituents At-line Assay}

Currently intrusive sampling of waste combined with costly preparation for analysis are used to determine the RCRA- and WIPP-WAC required organics, metals, halogens, sulfur, Btu content, and ash content for mixed waste to be treated. Techniques which support characterization as part of the process line could achieve significant analytical savings and promote more efficient operations. Except for organics and sulfur, at-line non-destructive assay (NDA) is proposed as an alternative approach to the current sampling and analysis for chlorine-containing compounds, Btu, ash content and metals.

Commercial NDA methods using prompt gamma neutron activation analysis (PGNAA) are available. For example, the Btu content of coal is routinely measured by PGNAA for total hydrogen and microwave assay for water. PGNAA of chlorine-containing compounds in combustible waste has been demonstrated. The DOE Mixed Waste Focus Area conducted a performance test of PGNAA on surrogate waste drums containing known quantities of the RCRA metals of cadmium, chromium, nickel, 
mercury and lead. Drum fornulations are intended to simulate the types of wastes which would be subject to thermal treatment and include drums of organic and inorganic sludges. Concentrations of metals in the surrogate drum:s will cover a range from $300 \mathrm{ppm}$ to $20,000 \mathrm{ppm}$. Test results indicated that one vendor successfully identified the presence of the RCRA elements cadmium, mercury, and lead in all of the blind samples. Further, they made no incorrect identification of elements not present (there is no lead in drum 7). They also quantified these elements in all but one drum (drum 5) to within \pm 20 percent for a total percent score of 76.9 percent.

Use of methods such as PGNAA will not address all constituents which must be characterized. Therefore, the requirement for intrusive sampling is not entirely eliminated by use of PGNAA. However, advantages over batch sampling include performance of near-real-time elemental assays, and in-bulk assays that cover approximately 90 percent of the container contents versus the substantially smaller percentage covered through intrusive sampling. If NDA techniques can be demonstrated and used as a substitute for intrusive sampling, for even a percentage of containers, costs of utilizing a NDA system would be less than current. One example where NDA would be useful would be for a waste stream for which metals are the key concern and more frequent metal analysis is desired. It is estimated that testing of existing systenıs on mixed waste streams would cost a total of $\$ 500,000$ and take three more years.

\subsubsection{Bulk Assay of Radionuclides}

Replacement of laboratory radiochemical analyses with on-line monitoring of the neutron and gamma emitting radionuclides can be an effective means of improving front-end waste characterization. In this context, improvement means improving timeliness of information and enhancing the cost effectiveness of the overall characterization process while ensuring the ability to obtain the required quality of data. Bulk assay of radioactive waste in drums has been in use for over 20 years. However, the requirements embodied in waste acceptance criteria are in a constant state of flux. The applicability of specific waste assay systems to a planned treatment scenario and to specific waste streams within that scenario should be critically evaluated as part of the planning process. The candidate system requires evaluation both from the point of view of potential overkill as well as possibility of falling short in providing key analytical parameters for operational control. The base case envisions detailed radiochemical analysis as well as implementation of both neutron and gamma based NDA. In addition to the relatively straightforward consideration of analytical capability and interference, one possibility of reducing the dependence on expensive radiochemical data is to consider possible statistical relationships.

For example, planning should distinguish data that is important to safe handling of individual drums from data that, although it is acquired on a individual drum basis, is actually required to characterize the input waste stream. Such corsiderations are important in determining the type and level of uncertainty which can be tolerated for a particular measurement. If data is required to determine safety of handling, the planner must have knowledge of the overall uncertainty which is associated with that measurement parameter. The decision on whether a particular package is safe to handle by a given method clearly depends on the confidence ycu can place on the actual value of the parameter of interest. Thus both random and systematic (bias) uncertainties are important. If the data will be combined with data from other determinations of the same parameter in a larger number of drums, the random uncertainty becomes less important and tie potential bias in the measurements becomes controlling. This is because the relative contribution of the random component to the uncertainty in the sum of a large number of measurements becomes very small as the number of individual measurements becomes large. Since 
average values are sums divided by constants, this is also true of an average value determined from a large number of measurements. In these cases then it is knowledge of the uncorrected bias in a measurement which is important. One can envision a situation where the inventory of an input waste parameter, e.g., an individual isotope, can be obtained from a large number of relatively imprecise but unbiased measurements while safety of handling is determined based on an entirely different, less expensive, screening method for a gross parameter such as exposure rate.

Concepts for improving the efficacy of front-end characterization should also consider the availability of correlation and population characteristics in planning the relative uses of radiochemical measurements and nondestructive assay in a complete characterization program. A model for such a plan could be the strategies used by commercial nuclear plant licensees in demonstrating compliance with $10 \mathrm{CFR} 61$. Isotopes which must be reported in waste shipments but are difficult to measure are determined radiochemically in samples submitted on a 6 to 24 month frequency. Correlation are established with isotopes which are easy to measure nondestructively or even to gross measurements or exposure rate determinations. The values of the difficult to measure isotopes are then reported in waste shipments based on a scaling factor relationship to an easy, routine measurement which had been established in the correlation studies. Such relationships could be established for whole waste streams or definable fractions of waste streams by a waste generator. Relatively simple measurements could then be used for treatment process and input control. Such statistical studies need only be repeated as required to reflect possible changes in waste stream characteristics.

Combinations of the above methods hold promise for reducing some of the resource burden associated with front-end waste characterization. For example, radiochemistry laboratory costs are 40 percent of the radiological characterization costs (Table 2-1). This could be substantially reduced through the use of statistical correlation.

As studies are conducted to determine the amounts and types of measurements and assay needed, additional refinements to NDA systems should be investigated. Assay measurement protocols might be improved by software interfaces which consider the results of radiography, non-radiological measurements, and characteristics inferred from associated methods to correct raw assay results.

In general, NDA systems currently in use for waste assay have not been proven effective for TRU waste sludge matrices and a sizable fraction of the debris waste forms in inventory. Therefore, much of the development work focuses on TRU waste specifically there is a need for the development of calibration alternatives to the standard compensation paradigm. Methods are required for determining and correcting for a broad range of interference issues, compensating for limitations in the available detection technologies, and quantifying measurement uncertainties. Appendix $\mathrm{C}$ contains additional detailed discussion regarding Waste NDA limitations and capabilities.

Visual examination as required by WIPP for front-end characterization could be partially replaced with examination by radiography to the extent practical. Radiographic techniques have been demonstrated to be acceptable for the identification and interception of free liquids, aerosol and pressurized gas cylinders, and heavy metals in bulk form (e.g., lead shielding). Some gross measurement of average atomic number of the matrix is also possible. Because the costs of opening a drum in a contained setting are so high, replacement of visual inspection with inspection by radiography may reduce inspection costs up to a factor of 50 for each drum for which opening can be avoided. Performance testing of advanced radiography systems should be compared with those in present use. A goal of 99 percent identification 
of all prohibited items and 100 percent identification of prohibited items that could cause off-normal conditions in the treatment plant should be achieved if visual inspection is to be eliminated.

Gamma-based assay systems such as computed tomography have the potential to quantitatively differentiate between transuranic and low-level radioactive wastes and provide needed isotopic information. These systems use active computed gamma ray tomography (ACT) to map the attenuation of the drum's contents to a specific volume element. ACT is combined with passive computed tomography (PCT), which localizes and identifies the radioactivity to a specific volume element in the drum. These systems require continued work to reach production throughput levels, optimize data acquisition, and to understanc total uncertainty.

Neutron-base assay systems such as PGNAA, described above, or Pulsed Fast-Thermal Neutron Analysis, also have the potential to extend the capability of current passive/active neutron instruments. These systems have source-position ("imaging") capability and use flux monitors to detect matrix in homogeneities. Development work is needed to finalize assay methods and algorithms and perform demonstrations.

It is estimated that further development of both statistical approaches and instrumentation will require four years and approximately $\$ 5$ million dollars to complete, based upon current plans.

\subsection{Process Equipment and Off Gas Controls}

Use of equipment specifically designed to treat heterogeneous waste with a radioactive component could lead to reduced characterization. This section analyzes potential improvements to process equipment and monitoring. Table 3-2 summarizes the potential improvements for process equipment and off gas controls.

Table 3-2 Process Equipment and Off gas Controls

\begin{tabular}{|l|l|c|c|r|}
\hline $\begin{array}{l}\text { Process Improvement } \\
\text { Design for Criticality }\end{array}$ & Irnpact on Characterization & $\begin{array}{c}\text { Time to } \\
\text { Develop } \\
\text { Alternative } \\
\text { year }\end{array}$ & $\begin{array}{c}\text { Cost to } \\
\text { Develop } \\
\text { Alternative }\end{array}$ & $\begin{array}{c}\text { Cost to Run } \\
\text { Alternative } \\
\text { per year }\end{array}$ \\
\hline $\begin{array}{l}\text { Criticality Engineering } \\
\text { Robust Off gas } \\
\text { Controls }\end{array}$ & $\begin{array}{l}\text { Eliminates degree of } \\
\text { accuracy needed for front } \\
\text { end rad characterization }\end{array}$ & 3 & $\$ 1,500,000$ & $\$ 0$ \\
\hline Mercury & $\begin{array}{l}\text { Reduce percentage of } \\
\text { sampling and analysis }\end{array}$ & 2 & $\$ 3,000,000$ & $\$ 50,000$ \\
\hline C12/HCl & $\begin{array}{l}\text { Reduce percentage of } \\
\text { sampling and analysis }\end{array}$ & 3 & $\$ 2,000,000$ & $\$ 50,000$ \\
\hline Total & & & $\$ 6,500,000$ & $\$ 100,000$ \\
\hline
\end{tabular}




\subsubsection{Maximize Efficiency and Treatment Technology}

A number of improvements to baseline incineration have been proposed, are under development, or have been demonstrated for treating mixed wastes. Use of melter technologies are a specific focus of technology development (Battleson et al. 1994; EG\&G Idaho 1992; Feizollahi et al. 1994; Feizollahi and Quapp 1995; Geimer et al. 1992; Hassel et al. 1994; Mayberry et al. 1991, Roesener et al. 1992; Soelberg et al. 1994; Soelberg et al. 1996; Surma et al. 1993; and MWFA Melter Technology Strategy 1996). Many of these technologies generate a glass or rock-like final waste form which requires no further stabilization. Therefore, the potential for volume reduction can impact characterization costs because less samples would be required to meet WIPP WAC or Subtitle C WAC.

The robust design of melter alternative processes may contain engineered criticality safety features that allow larger quantities of fissile material to be introduced into the system without concern of violating safety limits. This being the case, the need for accurate front-end characterization of waste for fissile material concentration is not as demanding as for the base case system. Generator-supplied process and waste generation data may be sufficient to envelop the fissile material mass concentration using conservative uncertainty factors for some waste streams. Therefore, no need is identified for 55 -gallon drum waste NDA systems for up-front waste characterization to determine the fissile material mass.

Criticality safety must be addressed during processing. The electric high-temperature melter is a vessel lined with refractory into which the sized waste material is introduced. The liquid melt has been demonstrated to have an affinity for fissile materials and hence will need to be monitored for criticality safety purposes. Due to the nature of a melter, the means of assessing criticality safety during the melt will most likely be a subcritical reactivity type of measurement. This method requires the use of a neutron source necessitating shielding and/or an exclusion zone for personnel if the criticality safety analysis requires continuous monitoring. Due to feed rate and fissile material concentrations, this will likely not be the case, and holdup could be assessed during a shutdown mode at a prespecified frequency.

To improve operation of a rotary kiln incinerator such that the needs for precise measurement of radionuclides for criticality control is minimized, work similar to that described above would be required. However, the rotary kiln process and resultant ash generation may require more monitoring. It is estimated that continued development to achieve criticality safe systems will take three years at a cost of $\$ 1.5$ million.

\subsubsection{Improve Off gas Controls}

A system for highly efficient removal of mercury from either hot or cooled off gases could reduce characterization costs. If reliable mercury capture can be accomplished in the off gas, then feed characterization could be minimized. Current absorbents cannot be loaded heavily, and are expensive. Preliminary development of more efficient technology is in progress. Demonstration of the system at low and high temperatures is needed, which is estimated to cost $\$ 3$ million and would take approximately two years. This cost estimate is based on similar work currently funded by the MWFA.

A system for high temperature removal of chloride and elemental chlorine from off gases could eliminate the need for $\mathrm{HCl}$ and chlorine monitoring. This system also may reduce the potential for dioxin formation from chlorinated precursors formed from chlorine/chloride in the off gas cooling zone, thus potentially eliminating the need for dioxin monitoring when this is the major route for dioxin formation. 
Development of a high temporature chloride/chlorine absorbent system would require a laboratory study at an estimated cost of $\$ 500,(000$. Subsequent pilot plant and demonstration work on hot systems would cost an additional $\$ 1500,000$. The total program is estimated to take three years.

\subsection{Continuous Monitoring}

The principal reason for investing in continuous emissions monitors (CEMs) is that the public demands a high level of assurance and documentation that waste treatment processes are consistently being operated in a safe, properly controlled, and regulatory compliant manner. Continuous monitoring is preferred under the Revised Standards for Hazardous Waste Combustors [(61 FR 17357 - 17536) (April 19, 1996)] proposed by EPA. The proposed revised standards reflect the performance of Maximum Achievable Control Technologies (MAC' $)$ ) as specified by the Clean Air Act, hence the proposed rule is often referred to as the proposed MACT rule and the proposed standards are often referred to as the proposed MACT standards. Under the proposed standards, the application of continuous emissions monitoring for $\mathrm{HCl}, \mathrm{Cl}_{2}, \mathrm{Hg}$, semi-volatile metals (SVM), and low volatile metals (LVM) can replace feedstream analysis for those components and can eliminate consideration of those waste components during required comprehensive and confirmatory tests. This is especially important in the case of mixed waste, because of ALARA concerns, and because both the feedstream analysis and the testing, the latter comparable to the RCRA trial burn, are high cost activities.

CEMs can provide several benefits for waste treatment. By providing more complete and more timely information on emissions, they can enable better control for safe and compliant operation of treatment facilities, provide documentation of such operation, and help provide greater assurance of the quality of the final waste forms. These benefits address important public concerns regarding the siting and operation of incinerators or other thermal treatment equipment. Consequently, quality CEMs could help increase public acceptance of such facilities.

A number of off gas monitoring development and demonstration needs have been identified through DOE-sponsored projects (Dalton et al. 1992; French et al. 1994; Maraj, 1994; Cornelison et al. 1995; Eddy et al. 1995; and Soelberg et al. 1996). Specific recommended actions related to CEM development and testing have also been identified in the September 1996 draft document entitled, CEM Development Strategy: A Process and Supporting Information to Establish a CEM Technology Development Strategy. That document will be referred to in the following as the draft CEM TDS report. Those CEM application areas which impast up front characterization requirements and recommendations for action in those areas are summarized below; additional CEMs, more detailed descriptions, and recommendations are presented in the draft CEM TDS report. Specific requirements for CEM operation are outlined in the MWFA CEM Technology D $€$ velopment Requirements Document.

\subsubsection{Hg and Particulate Matter (PM) CEMs}

CEM for mercury $(\mathrm{Hg})$ are ccmmercially available and are currently undergoing 6-month or longer performance testing sponsored jointly by the DOE/EM and the EPA Office of Solid Waste. The purpose of these tests is to ascertain the availability and quantify the performance of commercial $\mathrm{Hg}$ to meet the performance specifications provided in the proposed MACT standard [61 FR 17495 - 17514 (April 19, 1996)]. The testing is being performed at commercial hazardous waste treatment facilities. No additional time or development cost is expected to be required. 


\subsection{2 $\mathrm{HCl}$ and $\mathrm{Cl}_{2} \mathrm{CEMs}$}

According to the proposed rule, $\mathrm{HCl} \mathrm{CEMs} \mathrm{have} \mathrm{been} \mathrm{proven,} \mathrm{are} \mathrm{commercially} \mathrm{available} \mathrm{worldwide,}$ and have been used at permitted municipal waste combustor sources and some hazardous waste combustors for many years. In addition, they are said to be inexpensive with purchase cost in the range of $\$ 12,000$ to $\$ 55,000$ [61 FR 17432 -17434 (April 19, 1996)]. $\mathrm{A} \mathrm{Cl}_{2} \mathrm{CEM}$ is currently being marketed by Opsis, a European CEM manufacturer and these devices have been certified for use in Germany [61 FR 17434 (April 19, 1996)]. Since continuous emissions monitoring for both $\mathrm{HCl}$ and $\mathrm{Cl}_{2}$ is specified as optional in the draft MACT rule, with the associated elimination of feedstream chlorine analysis and consideration of chlorine during comprehensive and confirmatory testing, it may be beneficial to establish one technique that can monitor both $\mathrm{HCl}$ and $\mathrm{Cl}_{2}$. Differential Optical Absorption Spectroscopy may be such a technique but field testing may be required to ascertain performance for compliance monitoring in the U. S. CEMs for total $\mathrm{HCl} / \mathrm{Cl}_{2}$ based on ion mobility spectrometry or mass spectrometry may also be feasible but these would also require performance validation. In any case, it may be useful for DOE /EM to participate with EPA in joint sponsorship of such validation as may be required, as is being done for $\mathrm{Hg}$ and PM CEMs. The testing will likely be performed at commercial hazardous waste treatment facilities, as in the $\mathrm{Hg}$ CEM and PM CEM cases. The test program will take approximately one year and cost $\$ 500,000$.

\subsubsection{Multi-metal CEMs}

Multi-metal CEMs that satisfy the Performance Specification in the proposed MACT rule [61 FR 17499 - 17502 (April 19, 1996)] are not yet commercially available. Nevertheless, the need for such CEMs in mixed waste treatment is clear. Development/validation of at least one multi-metals CEM was recommended in the draft CEM TDS report. The need is driven by ALARA concerns, public assurance requirements, a strong budgetary incentive to avoid otherwise required feedstream analysis costs for metals through the application of multi-metals CEMs, and potential future regulatory requirements for CEMs. There is much DOE and DoD activity in multi-metals CEMs. Several promising techniques for are based on atomic emission spectrometry (AES). They include Laser Spark (a.k.a. Laser Induced Breakdown Spectrometry), an in situ technique with somewhat disappointing field test results so far, and Inductively Coupled Plasma AES, an extractive technique with good field test results but needing size reduction to enable closer placement of the instrument to the stack. The Microwave Induced Plasma technique is another AES approach that also appears to have promise but it is not as developed as the other techniques. Development of an acceptable multi-metal CEM will take an additional two years and cost \$1 million.

\subsubsection{Volatile and Semivolatile Organics CEMs}

Technologies suitable for application in continuous monitoring for volatile and semivolatile organic compounds are commercially available. Examples include gas chromatography, mass spectrometry, and combinations. In 1995 the performance of five prototype organic compound CEMs was evaluated at the EPA Incineration Research Facility, Jefferson, Arkansas, under joint EPA and DOE/EM sponsorship ("Testing the Performance of Real-Time Incinerator Emission Monitors" Draft document, February 1996, available from Marta Richards, EPA National Risk Management Research Laboratory, Cincinnati, OH 45268). At present, regulations proposing or mandating these CEMs do not exist, largely because EPA has insufficient data to justify specific organic compound emission standards and CEM performance specifications. Nevertheless, application of organic compound CEMs for key compounds of concern to 
regulators and stakeholders, (i. e., selected principal organic hazardous compounds (POHCs)), or surrogate organic compounds, might have high value as real-time monitors of destruction and removal efficiency, (i. e., DRE monitors).

\subsubsection{Radionuclide CEMs}

The public has high fear and low acceptance of radionuclide emissions. Radionuclide continuous emissions monitoring is also an area in which DOE has unique needs and unique capabilities.

Radionuclide monitors based on detection of emissions (i. e., alpha particle, beta particle, or gamma ray emissions) from radioactive decay are available. Examples of the state of the art for such radioactivity CEMs are the Flow Through Alpha Monitor (FTAM), a real-time monitor developed at Los Alamos National Laboratory, and the alpha/beta/gamma sample and analyze monitor, available from EG\&G Berthold. The sample and analyze monitor does not provide real-time data, but has greater sensitivity (lower detection limits) than the real-time system. The FTAM has the ability to monitor the entire volume of stack gas, whereas the EG\&G Berthold examines only an extracted portion of the total stack gas flow.

Performance requirements for radionuclide CEMs have not been established. The applicable regulations are risk-based, not technology-based. They limit exposure to individuals in the vicinity of the stack to $10 \mathrm{mrem} / \mathrm{year}$. They do not specify limits for the radionuclide concentrations in the stack gas. As a consequence, although detection limits are crucial measures of performance for CEMs, it is not apparent how to define the detection lirnit requirements for radionuclide CEMs. In the draft CEM TDS report, an analysis was performed that related exposure limits to stack-gas concentrations, and estimated stack-gas concentrations based on waste feed and air pollution control system parameters. The principal technical conclusions and recommendations from that work were:

- Because of insufficient sensitivity, except in specific applications for some radionuclides, current CEMs based on measurenent of radioactivity (radioactivity CEMs) cannot be expected to consistently function as NESHAPs emissions compliance monitors.

- Typical steady-state concentrations of particulate-bound radionuclides in stack gas from mixed waste thermal treatment systems having two banks of HEPA filters in series are at least three orders of magnitude below the detertion limit for current state-of-the-art radioactivity CEMs.

- During normal operation, radioactivity CEMs used on the stack downstream of two or more banks of HEPA filters in series will. not be able to detect particulate radioactive releases to the environment in real-time. Such monitors can detect radioactivity in real-time only in the event of process upset conditions such as a failure of one or more HEPA filters upstream.

- Sampling of off gas followed by analysis provides greater sensitivity and lower detection limits than real-time monitoring and should continue to be used to provide actual cumulative albeit not real-time radionuclide release infonnation.

- Proper implementation of radioactivity CEMs will be critical to stakeholder acceptance of mixed waste treatment systems. Radioactivity CEMs for particulate-bound activity should be used upstream of the final bank of HEPA filters to detect an internal process upset condition in real-time while avoiding any increaised release of radioactivity. 
Additional recommendations regarding radionuclide CEMs are:

- Perform a rigorous assessment of the need for radionuclide CEM capability to support mixed waste treatment.

- Establish appropriate priority for radionuclide CEM development for support of DOE mixed waste treatment.

- Establish the performance requirements for radionuclide CEMs.

- Keep the door open to radionuclide CEM techniques that employ detection methods other than detection of emissions from radioactive decay. For radionuclides with long half-lives, e. g., Pu-239, such techniques may have better detection capabilities than those based on detection of emissions from radioactive decay.

\subsubsection{Cost Comparison}

Implementation of these recommendations is estimated to take one to two years at a cost of $\$ 6.5$ million. Table 3-3 provides a summary comparison of improvements to the base case system.

Table 3-3 Continuous Monitoring improvements

\begin{tabular}{|l|l|c|c|r|}
\hline CEM & Impact of Use & $\begin{array}{c}\text { Cost to } \\
\text { Develop, } \\
\$ \mathrm{M}\end{array}$ & $\begin{array}{c}\text { Time to } \\
\text { Develop, } \\
\text { years }\end{array}$ & $\begin{array}{c}\text { Annual } \\
\text { Cost to } \\
\text { run (FTE) }\end{array}$ \\
\hline Multi-metals & Relaxes feedstream metals analysis. & $\$ 1.0$ & 2 & $\$ 25,000$ \\
\hline $\mathrm{HCl} / \mathrm{Cl} 2$ & $\begin{array}{l}\text { Eliminate need for separate } \mathrm{HCl} \text { and } \mathrm{Cl} 2 \mathrm{CEMs} / \\
\text { Avoids } \mathrm{Cl} 2 / \mathrm{Cl} \text { feedstream analysis. }\end{array}$ & $\$ 0.5$ & 1 & $\$ 25,000$ \\
\hline Radioactivity & Potentially required & $\$ 5.0$ & $1-2$ & $\$ 25,000$ \\
\hline Mercury & Potentially required & $\$ 0.0$ & 1 & $\$ 25,000$ \\
\hline Total & & $\$ 6.5$ & & $\$ 100,000$ \\
\hline
\end{tabular}

\subsection{Final Waste Form Characterization}

Waste must be characterized after treatment to verify that the final waste form complies with regulatory treatment requirements, shipping requirements, and the receiving facility's applicable additional WAC. All final forms will require characterization for alpha, beta, and gamma emitting radionuclides in order to determine if the wastes meet the performance assessment related WAC requirements and/or NRC licensing requirements of the intended disposal facility.

There are two decision points that will determine how the final waste form must be characterized. The first decision point is based on transuranic radionuclide content: either the final waste form is TRU or not TRU waste. If the final waste form is TRU, the applicable disposal facility would be WIPP and the waste would need to meet all WIPP WAC and only WIPP WAC requirements.

If the final waste form is not TRU, i.e., it contains less than $100 \mathrm{nCi}$ of transuranic radionuclides per gram of waste, then the second decision point is based on RCRA regulatory requirements for disposal in a Subtitle $C$ facility or allowability of disposal in a Subtitle D facility. 
It is assumed that all wastes except non-thermally treated debris will require disposal in a Subtitle C facility. Assumed options for such disposal include the DOE Hanford and Nevada Test Site disposal sites and one commercial facility, Envirocare of Utah. In addition to the specific facility WAC, these wastes must meet the applicalle RCRA LDR treatment standards, which are assumed to require the TCLP and, as applicable, tota]. underlying hazardous constituent analysis. Analysis for residual PCBs is accomplished by analysis for UTS.

It is assumed that debris waste treated by non-thermal treatments to meet the debris alternative treatment standards can be disposed in $a$. Subtitle $D$ facility and will not require detailed chemical analysis. Based on current experience with the 1000 drums reviewed, that such waste would not be PCB contaminated, therefore would not require aralysis for residual PCBs after treatment. Potential improvements to final waste form characterization is discussed below.

\subsubsection{Issue a WIPP WAC for Treated Waste}

The current WIPP WAC contains requirements based upon disposal of untreated waste at WIPP. Concerns over the presence organics and gas generation do not exist for thermally treated waste and the WAC requirements relatel to head space gas could be eliminated in a WIPP WAC specifically addressing treated waste.

It is assumed additionally that the WIPP WAC requirements addressing safe transportation and issues related to long term storage o: untreated TRU waste would not apply to the treated waste form. Therefore, the requirements of the current WIPP WAC related to transportation of untreated waste should also be examined. Table 3-4 illustrates the potential WIPP WAC which could be established for treated waste, along with associated costs. The total cost for the proposed treated WIPP WAC is $\$ 1,588,000$ as compared to $\$ 1,755,000$ for meeting the current WIPP WAC with the treated waste.

Table 3-4 Cost for final waste form characterization for treated WIPP WAC - based on 1,000 containers input - base case

\begin{tabular}{|l|r|r|r|r|r|r|}
\hline \multicolumn{1}{|c|}{ Task/Test } & Cost each & $\begin{array}{r}\text { Fraction } \\
\text { Analyzed }\end{array}$ & $\begin{array}{c}\text { Final No. } \\
\text { of } \\
\text { Drums }\end{array}$ & $\begin{array}{c}\text { Number } \\
\text { of } \\
\text { Analyses }\end{array}$ & $\begin{array}{c}\text { Total Cost } \\
\text { to Nearest } \\
\$ 1,000\end{array}$ & $\begin{array}{c}\text { Total Cost } \\
\text { to Nearest } \\
\$ 1,000\end{array}$ \\
\hline take samples & $\$ 12,000$ & 0.1 & 1000 & 100 & $\$ 1,200,000$ & $\$ 1,200,000$ \\
\hline alpha, beta, gamma (bulk assiy) & $\$ 264$ & 0.1 & 1000 & 100 & $\$ 26,400$ & $\$ 26,000$ \\
\hline Total organic carbon & $\$ 47$ & 0.1 & 1000 & 100 & $\$ 4,700$ & $\$ 5,000$ \\
\hline Total metals & $\$ 366$ & 0.1 & 1000 & 100 & $\$ 36,600$ & $\$ 37,000$ \\
\hline Radiography & $\$ 44$ & 1.0 & 1000 & 1000 & $\$ 44,000$ & $\$ 44,000$ \\
\hline PAN/gamma & $\$ 242$ & 1.0 & 1000 & 1000 & $\$ 242,000$ & $\$ 242,000$ \\
\hline UHC/UTS & $\$ 340$ & 0.1 & 1000 & 100 & $\$ 34,000$ & $\$ 34,000$ \\
\hline Total & & & & & $\$ 1,587,700$ & $\$ 1,588,000$ \\
\hline
\end{tabular}




\section{An Improved Characterization and Monitoring Configuration}

This section presents a synthesis of the requirements and improvements identified in previous sections and provides a description of the configuration of an improved characterization and monitoring configuration for waste treatment, along with an assessment of costs.

The improved configuration would rely upon a process designed and engineered to incorporate criticality safety requirements. CEMs need to be further developed so that they could effectively document compliance. CEMs can also provide a substitute for some feed stream analysis, particularly for mercury, other regulated metals, and chlorides.

The WIPP WAC may need to be changed to specifically address treated waste. Some of the current requirements in the WIPP WAC, such as the requirements for head space gas sampling, should no longer apply because any VOCs would be destroyed through treatment. Other requirements, such as quantification of hydrogen or methane, are necessary to assure safe transportation of untreated waste and should not apply either once the waste is treated. However, in order to establish a basis for an amended WAC, additional characterization and understanding of how treated waste will perform during long term disposal may be required.

Table 4-1 provides a summary comparison of current requirements and approaches to potential alternative approaches. 
Table 4-1 Comparison of how requirements are met under current and proposed approach

\begin{tabular}{|l|l|l|}
\hline \multicolumn{1}{|c|}{ Requirement } & \multicolumn{1}{|c|}{ Current Approach } & \multicolumn{1}{c|}{ Proposed Approach } \\
\hline Btu & ASTM D3286-91a & Engineering calculations, RTR \\
\hline Ash content & ASTM D3174-89 & Engineering calculations, RTR \\
\hline Hydrocarbon/organics & SW-846 Series 8000 methods & CEMS or qualitative evaluation \\
\hline Particulate & $\begin{array}{l}\text { EF'A Manual Method 5 PM Sampling } \\
\text { Train }\end{array}$ & CEMS \\
\hline Semi-volatile metals & $\begin{array}{l}\text { SW846 Method 6010, 7470 \& 8000 } \\
\text { series }\end{array}$ & at-line assay/CEMS \\
\hline Low-volatile metals & $\begin{array}{l}\text { SW846 Method 6010, 7470 \& 8000 } \\
\text { series }\end{array}$ & at-line assay/CEMS \\
\hline Mercury & $\begin{array}{l}\text { SW846 Method 6010, 7470 \& 8000 } \\
\text { series }\end{array}$ & at-line assay/CEMS \\
\hline Chlorine & ASTM D481 on solids \& SW 846-9056 & at-line assay/CEMS \\
\hline Radionuclides & $\begin{array}{l}\text { Gross alpha/beta SW 846-9310, lab } \\
\text { SCIPs for gamma }\end{array}$ & $\begin{array}{l}\text { Alpha CEM, criticality } \\
\text { prevention engineering, } \\
\text { improved radiography }\end{array}$ \\
\hline So ${ }_{x}$ & SCI 2 Analyzer, NDIR, NDUV & bulk assay \\
\hline No ${ }_{x}$ & No analyzer, NDIR, chemiluminescent & at-line assay \\
\hline Final Waste Form & $\begin{array}{l}\text { Receiving facility WAP or WIPP WAC } \\
\text { WIPP WAC modified for treated } \\
\text { waste }\end{array}$ \\
\hline
\end{tabular}


Table 4-2 Ideal treatment front end waste characterization costs based on 1,000 containers ( $10 \%$ sampling)

\begin{tabular}{|c|c|c|c|c|c|c|c|c|c|c|}
\hline Task/Analysis & Method & $\begin{array}{l}\text { Fraction } \\
\text { of drums } \\
\text { analyzed }\end{array}$ & $\begin{array}{l}\text { No. of } \\
\text { sludge } \\
\text { drums }\end{array}$ & \begin{tabular}{|c|}
$\begin{array}{c}\text { No. of } \\
\text { analyses } \\
\text { per sludge } \\
\text { drum }\end{array}$ \\
\end{tabular} & $\begin{array}{l}\text { No. of } \\
\text { debris } \\
\text { drums }\end{array}$ & $\begin{array}{c}\text { No. of } \\
\text { analyses } \\
\text { per debris } \\
\text { drum }\end{array}$ & $\begin{array}{l}\text { Total of } \\
\text { drums/ } \\
\text { analyses }\end{array}$ & $\begin{array}{l}\text { Sampling/ } \\
\text { Analysis } \\
\text { cost/each }\end{array}$ & $\begin{array}{c}\text { Sampling/ } \\
\text { Analysis } \\
\text { Cost actual }\end{array}$ & $\begin{array}{c}\text { Sampling/ } \\
\text { Analysis } \\
\text { Cost } \\
\text { rounded } \\
\end{array}$ \\
\hline Take samples & Sampling/Analysis Plan & 0.1 & 30 & & 70 & & 100 & $\$ 12,000$ & $\$ 1,200,000$ & $\$ 1,200,000$ \\
\hline Ignitability & SW $846-1010$ & 0.1 & 30 & 1 & & & 30 & $\$ 100$ & $\$ 3,000$ & $\$ 3,000$ \\
\hline Corrosivity & SW $846-1011$ & 0.1 & 30 & 1 & & & 30 & $\$ 46$ & $\$ 1,380$ & $\$ 1,000$ \\
\hline Reactivity & SW 846 II 7.3 & 0.1 & 30 & 1 & & & 30 & $\$ 2,700$ & $\$ 81,000$ & $\$ 81,000$ \\
\hline Organics & SW $846-8000$ series & 0.1 & 30 & 1 & 70 & 3 & 240 & $\$ 1,021$ & $\$ 245,040$ & $\$ 245,000$ \\
\hline Metals & At-line assay/CEMs & 0.1 & 30 & 1 & 70 & 3 & 240 & $\$ 33$ & $\$ 7,920$ & $\$ 8,000$ \\
\hline Chlorine & At-line assay/CEMs & 0.1 & 30 & 1 & 70 & 3 & 240 & $\$ 33$ & $\$ 7,920$ & $\$ 8,000$ \\
\hline Btu & At-line NDA & 0.1 & 30 & & & & 30 & $\$ 33$ & $\$ 990$ & $\$ 1,000$ \\
\hline Alpha, beta, gamma & bulk assay & 0.1 & 30 & 1 & 70 & 3 & 240 & $\$ 264$ & $\$ 63,360$ & $\$ 63,000$ \\
\hline Radiography & Lab SOPs & 1 & 300 & 1 & 700 & 1 & 1000 & $\$ 44$ & $\$ 44,000$ & $\$ 44,000$ \\
\hline NDA (PAN) & Lab SOPs & 1 & 300 & 1 & 700 & 1 & 1000 & $\$ 44$ & $\$ 44,000$ & $\$ 44,000$ \\
\hline NDA (gamma) & Lab SOPs & 1 & 300 & 1 & 700 & 1 & 1000 & $\$ 198$ & $\$ 198,000$ & $\$ 198,000$ \\
\hline Total & & & & & & & & & $\$ 1,896,610$ & $\$ 1,896,000$ \\
\hline
\end{tabular}




\subsection{Improved Characterization and Monitoring Configuration Cost Summary}

Characterization and monitoring costs for the improved characterization and monitoring configuration can be summarized into the following categories: 1) front-end characterization, 2) process monitoring, 3) off gas characterization, and 4) final waste form characterization.

\subsubsection{Front-End Characterization}

Front-end characterization is conducted to provide statistical confidence in the composition of accepted wastes. By designing an efficient system, using continuous monitors, and employing additional off gas controls, an improved configuration should result in the requirement to conduct a smaller percentage of sampling to obtain this confidence. Table 4-2 shows the estimated costs incurred through front-end characterization activities based on sampling ten percent of the incoming wastes to allow comparison across the cases. However in an improved scenario, the objective would be to minimize the overall percentage. The greatest cost savings can be achieved through reduction in the number of drums to be opened. A combined strategy of use of CEMs and controls for metals and chlorides, with use of remote techniques for assay of organic supports achievement of this approach. The following assumptions were made regarding front-end characterization costs:

1. Each container of waste will be examined by improved radiography to isolate containers with prohibited contents.

2. Ten percent of all drums will be verified and/or sampled prior to processing, three samples will be collected from each heterogeneous waste container. Waste stream variability maty ultimately determine the percent of drums verified. The objective is to ensure that waste feed is within operational parameters.

3. Direct radiation readings for gamma-emitting radionuclides will replace isotopic analyses.

\subsubsection{Process Monitoring}

Process monitoring costs, given the small number of parameters monitored for, tend to be small relative to other characterization and monitoring costs. Therefore, process control costs are considered negligible and are assumed to be similar to other cases.

\subsubsection{Off gas Monitoring ardd Analysis}

Costs for off gas monitoring and analysis for the improved configuration are estimated at $\$ 208,000$. Table 4-3 shows cost for operating all CEMs desired. These costs reflect more emphasis on continuous monitoring, and use of CEMs for a wider variety of waste parameters. Costs are based on labor and operational costs for operating the CEMS. 
Table 4-3 Operating Costs for off gas monitoring and analysis based on 1,000 containers - improved configuration

\begin{tabular}{|l|r|}
\hline \multicolumn{1}{|c|}{ Monitor } & \multicolumn{2}{c|}{$\begin{array}{c}\text { Operating costs to } \\
\text { Nearest } \$ 1,000\end{array}$} \\
\hline Strip Chart Recorder & $\$ 26,000$ \\
\hline CO Analyzer & $\$ 8,000$ \\
\hline O2 Analyzer & $\$ 8,000$ \\
\hline CO2 Analyzer & $\$ 8,000$ \\
\hline NOx Analyzer & $\$ 8,000$ \\
\hline SO2 Analyzer & $\$ 8,000$ \\
\hline THC Analyzer/ Probe/ Heated & $\$ 10,000$ \\
\hline Sample Line & $\$ 10,000$ \\
\hline Opacity Meter & $\$ 25,000$ \\
\hline Multi-metal & $\$ 25,000$ \\
\hline Mercury & $\$ 25,000$ \\
\hline Particulate matter & $\$ 25,000$ \\
\hline HCl/Cl2 & $\$ 22,000$ \\
\hline Radiation & $\$ 208,000$ \\
\hline Total & \\
\hline
\end{tabular}

\subsubsection{Final Waste Form Characterization}

Waste must be characterized after treatment to verify that the final waste form complies with regulatory requirements as well as the receiving facilities' WACs. Waste product analysis requirements include the TCLP to determine if the final waste form does not exhibit toxicity characteristic. Analysis for residual PCBs is accomplished by analysis for Universal Treatment Standards (UTS) LDR. The WIPP WAC requirements addressing safe transportation and issues related to long term disposal of untreated TRU waste are not addressed because they should not apply to a treated waste form. Estimated costs for final waste form characterization total $\$ 555,695$ (Table 4-4). These costs are based on the following assumptions:

Several assumptions have been made concerning the volume of treated waste:

1. Treated debris (slag) and solidified off gas solids will be placed in 55 gallon drums (limited to $800 \mathrm{lb}$. per drum) for ultimate disposal.

2. Treatment of debris will result in a 6:1 volume reduction by use of a melter type process. The basis of this assumption is an assumed overall 50 percent mass loss (due to volatilization, decomposition, and oxidation of organics, moisture, carbonates, and nitrates), and an assumed three fold change in density from approximately $62 \mathrm{lb} / \mathrm{ft}^{3}$ (specific gravity of $\sim 1$ ) to approximately $200 \mathrm{lb} / \mathrm{ft}^{3}$ (specific gravity of $\sim 3$ ). 
3. Ten percent of the final waste drums will be sampled. 1,000 input drums will be volume-redured to around 170 output drums, of which 17 will be analyzed. The ten percent sample may change based on process throughput, batch vs. continuous processing, and total process days per year. However, ten percent is assumed for this document.

Table 4-4. Cost for final waste form characterization based on 1,000 containers processed creating 170 final robust treatment.

Table 4-4 Final Waste Form Characterization under improved system

\begin{tabular}{|l|r|c|c|c|c|}
\hline \multicolumn{1}{|c|}{ Task/lest } & Cost & Fraction & $\begin{array}{c}\text { Final \# of } \\
\text { Drums }\end{array}$ & $\begin{array}{c}\text { \# of } \\
\text { Analyses }\end{array}$ & Total Cost \\
\hline take samples & $\$ 12,000$ & 0.1 & 350 & 35 & $\$ 420,000$ \\
\hline alpha, beta, gamma & $\$ 264$ & 0.1 & 350 & 35 & $\$ 9,240$ \\
\hline Total organi; carbon & $\$ 47$ & 0.1 & 350 & 35 & $\$ 1,645$ \\
\hline metals & $\$ 366$ & 0.1 & 350 & 35 & $\$ 12,810$ \\
\hline radiography & $\$ 44$ & 1 & 350 & 350 & $\$ 15,400$ \\
\hline PAN/gamme. & $\$ 242$ & 1 & 350 & 350 & $\$ 84,700$ \\
\hline UHC/UTS & $\$ 340$ & 0.1 & 350 & 35 & $\$ 11,900$ \\
\hline Total & & & & & $\$ 555,695$ \\
\hline
\end{tabular}

\subsection{Total Estimated Cost}

The total estimated cost for the improved system is tabulated in Table 4-5.

Table 4-5 Costs for Improved Characterization and Monitoring

\begin{tabular}{|l|r|}
\hline Activity & \multicolumn{1}{|c|}{ Costs } \\
\hline Front-end & $\$ 1,896,000$ \\
\hline Process & $\$ 56,000$ \\
\hline Continuous Emissions & $\$ 208,000$ \\
\hline Final Waste Form & $\$ 556,000$ \\
\hline Total & $\$ 2,716,000$ \\
\hline
\end{tabular}




\section{WIPP}

\subsection{WIPP Base Case}

This section examines the base case waste characterization program for the WIPP facility where waste is characterized for shipment to WIPP without treatment. Waste characterization program is described in detail in the TRU Waste Characterization Quality Assurance Program Plan (QAPP) (DOE 1995a). As with other costs, program costs are normalized to a theoretical waste population of 1,000 drums, consisting of 70 percent heterogenous waste and 30 percent sludges.

The WIPP was designed as a research and development facility to demonstrate the safe disposal of radioactive wastes produced by national defense activities. The WIPP is in southeastern New Mexico, approximately $38 \mathrm{~km}$ east of Carlsbad. The facility consists of a mined repository level at $657 \mathrm{~m}$ below the ground surface as well as necessary support facilities at the surface. The repository level is in the Salado Formation of marine bedded salts. Over a 35-year disposal phase, the DOE plans to dispose of approximately 6.2 million cubic feet of TRU waste in the WIPP facility. These TRU wastes from the DOE defense program result primarily from plutonium reprocessing and fabrication, research and development activities, environmental restoration, and decontamination and decommissioning programs at various sites.

The wastes intended for disposal at the WIPP include a variety of forms ranging from laboratory tools, glassware, and equipment to solidified wastewater treatment sludges, contaminated soil/gravel, and decommissioning debris wastes. Much of the waste will be subject to regulation as hazardous waste under the RCRA as well as regulation under Atomic Energy Act (AEA). Characterization of TRU wastes will be a critical element in the overall strategy to demonstrate compliance with all relevant regulations. The waste characterization program involves obtaining the required chemical, radiological, and physical data on the waste streams using all methods appropriate including sampling and analysis, bulk waste measurements, waste inspection, and/or acceptable knowledge of the processes by which the wastes were generated. In the case of the WIPP, this information must be correlated to a series of matrix parameter categories established in the Waste Isolation Pilot Plant Transuranic Waste Baseline Inventory Report (WTWBIR) (DOE 1995b). These matrix parameter categories and their related descriptions define the waste inventory which the DOE plans for disposal at the WIPP, and that forms the basis for compliance representations submitted by the DOE to the cognizant regulatory authorities for the WIPP. Ultimately, the waste that may be disposed at WIPP will be limited to waste for which adequate characterization data are available and which falls within the inventory envelope described in compliance documents.

To ensure compliance, the DOE will need to confirm that the actual WIPP waste inventory matches to an acceptable degree the inventory that forms the basis of the performance assessment (PA) computations and the 40 CFR Part 191 Compliance Certification Application. The EPA Office of Radiation and Indoor Air is responsible for reviewing the 40 CFR Part 191 Certification Application, and issuing and enforcing of the Certificate of Compliance with 40 CFR Part 191.

The WIPP facility is defined as a miscellaneous unit subject to regulation under 40 CFR Part 264, Subpart X. Permit applications for miscellaneous units must describe the wastes to be managed and assess the potential environmental impacts associated with the proposed waste management activities. 
This information must include a description of the physical form of the waste as well as the appropriate EPA hazardous waste numbers. The waste characterization program must provide the data required for the RCRA permit application as well as subsequent confirmation that wastes shipped to WIPP conform to the waste profiles on which issuance of the RCRA permit was based.

The New Mexico Environmental Division (NMED) is responsible for reviewing the WIPP RCRA permit application and issuing the WTPP disposal phase permit. The NMED and EPA Region VI are responsible for enforcing RCRA regulations and permit provisions at the WIPP facility.

The WIPP Land Withdrawal Act that was amended in September 1996 exempts wastes disposed of at the WIPP from the RCRA land disposal restrictions. The DOE is not required to treat mixed wastes or demonstrate compliance with the "no migration" standards prior to disposal of mixed waste at the WIPP facility.

In 1989, the DOE obtained the first Certificate of Compliance from the NRC to ship contract-handled TRU waste (CH TRU) in the Transuranic Package Transporter II (TRUPACT-II). Limits are imposed on container contents of hydrogen, methane, and potentially flammable VOCs based on flammability concerns. The Certificate of Compliance also limits the quantity of TRU that can be shipped in a TRUPACT-II based on both :issile grams equivalent (FGE) and thermal power. Waste characterization program data are required to verify compliance with the shipping limits contained in the Certificate of Compliance. The NRC is responsible for reviewing and approving the Safety Analysis Report for Packaging (SARP), and issui:ng and enforcing the Certificate of Compliance for the TRUPACT-II.

The NRC is responsible for reviewing and approving the Safety Analysis Report for Packaging (SARP), and issuing and enforcing the Certificate of Compliance for the TRUPACT-II.

The WIPP facility must receive EPA certification that it meets the radioactive waste disposal standards 40 CFR 191. Data are required for the WIPP submittal of an application for certification regarding both the radioactive and hazardous components of the waste.

\subsection{Waste Characterization Program}

The waste characterization program consists of testing and sampling, and analytical techniques that will be used to characterize TRU waste at sites that are planning to send those wastes to the WIPP. The waste characterization program wil be applied to TRU wastes in retrievable storage as those wastes are retrieved. The waste charactirization program will be applied to newly-generated TRU waste as it is generated. The waste characterization program is designed for the characterization of TRU waste on a waste stream basis. A waste stream is defined as waste material generated from a single process or activity that is similar in matrrial, physical form, isotopic makeup, and hazardous constituents. Waste characterization requirements; are different for different waste streams (i.e., debris versus homogeneous solids). The emphasis on waiste stream representativeness for many parameters provides a source of some flexibility in developing alternative waste characterization strategies.

The WIPP QAPP provides definitions and requirements for the frequency of testing, sampling, and analysis required for retrievaloly stored and newly generated TRU waste. Because it is the waste stream that is being characterized, there are several parameters that do not have to be individually determined 
for each waste container. When only a fraction of the waste containers will undergo a specific characterization technique (e.g., total metal analysis), random sampling of waste streams is required to ensure that data are representative. To ensure data comparability between all participating sites, the WIPP QAPP specifies minimum testing, sampling, and analytical requirements for each of the methods included in the characterization program. Required methods are presented in detail in the Transuranic DOE 1995 and Test Methods for Evaluating Solid Waste, Physical/Chemical Methods Third Edition, Final Update I, and Final Update II (SW-846) (EPA 1995). Alternate methods are also possible but must be submitted to the DOE Carlsbad Area Office (CAO) for approval.

In addition to the sampling and measurement methods, the waste characterization program requires the use of acceptable knowledge to fulfill several of the requirements for waste characterization. Use of acceptable knowledge refers to the determination of the hazardous attribute of the waste based on existing knowledge of the materials or processes used to generate waste. Acceptable knowledge may incorporate or be based on records accompanying the waste; administrative, procurement, and quality controls associated with the processes generating the waste; past sampling and analytical data; material inputs to the waste generating process; and the time period during which the waste was generated. Information required for characterizing waste using acceptable knowledge includes the physical form of the waste and documented changes to the process and/or material inputs.

\subsection{Waste Stream Identification}

The waste characterization program uses acceptable knowledge activities to delineate waste streams. After this delineation, acceptable knowledge is also used to make all hazardous waste determinations for debris waste and to determine whether homogeneous solids and soil/gravel are RCRA-listed wastes. Having distinguished relatively homogeneous waste forms from heterogeneous waste forms, acceptable knowledge is used for RCRA characterization of waste streams for which it is difficult to obtain a representative sample because of physical form and/or heterogeneous composition (e.g., metal, glass, combustibles). In these instances acceptable knowledge will be verified by radiography, as discussed below.

\subsubsection{Radiography}

Radiography is used to directly confirm physical characteristics of the contents of a waste container that are observable by analyzing the absorption of $x$-rays within the material contents. Radiography is used to verify the proper classification of wastes by the unique waste identifier code. It is also used to verify the absence of any nonconforming materials and conditions in the waste container that can be verified by this type of examination. Nonconforming materials and conditions are those not acceptable under the WIPP WAC. Examples of potentially nonconforming materials or conditions observable by radiography include the presence of excess free liquids or sealed compressed gas containers. Radiography will also verify the physical form of debris wastes and by association, their RCRA constituents. 


\subsubsection{Visual Examination}

Visual examination is used ais a quality control check on radiography and to determine the same parameters as radiographic methods except that it is applied to only a relatively small sample of the overall population examined by radiography. Visual examination is used to directly confirm physical characteristics of the contents; of a waste container by unpacking and physically examining the contents. Other parameters, such as the nature and weights of component materials, can also be directly observed while conducting visual exanination and used to establish confidence in the radiographic data.

The number of containers that must be visually examined is determined using the hyper geometric distribution. To utilize the hyper geometric approach, the acceptable level of uncertainty in the estimate of the proportion of miscertified waste (along with the information on the previous percentage of miscertified waste) determines the number of containers that must be examined. The rationale and details of this methodology are discussed in detail in (Appendix A) the QAPP (DOE 1995a).

\subsubsection{Radioassay}

To ensure compliance with all requirements, valid assay data on all of the following parameters are required: activities of all the individual isotopes of significance, total alpha activity, Pu-239 FGE, and thermal power. No specific rnethod is required to perform radioassay in the WIPP waste characterization program. Any method will be acceptable if it meets established QC specifications for the system. A variety of NDA technologies may be effective in meeting the requirements of the program. These technologies utilize neutron and gamma ray measurement systems: in active and passive modes; with and without external source correction strategies; with and without computed tomography; and a variety of modifications, functionally equivalent alternatives, multiple combinations, or hybrids of these systems.

\subsection{Headspace Gas Sampling}

The target analytes for the headspace gas sampling and analysis component of the TRU waste characterization program include hydrogen, methane, and VOCs.

Gas samples are collected in SUMMA7 passivated canisters from the headspace of waste containers. Laboratories must use either gas mass spectrometry (MS) or gas chromatography (GC) for the analysis of hydrogen and methane. A ternate analytical methods, which meet all of the required QAOs, may be submitted to CAO for approval.

The QAPP permits a second method for the analysis of headspace gases. This is the use of Fourier Transform Infrared Spectroscopy (FTIR) for the analysis of headspace gases for the waste characterization program. FTIR is a rapid and cost-effective method for analyzing headspace gases. It may be used as an integrated, on-line sampling and analysis system or it may be used as a stand alone analytical system using samples drawn in the same manner as prescribed for the MS, GC, and GC/MS analytical methods. The FTIR method is less labor-intensive, is virtually real time for on-line systems, and is far less expensive than the MS, GC, and GC/MS methods. 


\subsection{Waste Sampling and Analysis}

Samples must be collected from waste containers of homogenous solids and soil/gravel. These samples are required to be analyzed for total VOCs, total semivolatile organic compounds (SVOCs), and total metals. PCBs have been identified as a contaminant in some organic sludges. Therefore, organic sludge waste streams must also be analyzed for PCBs.

\section{VOCs/SVOCs}

Laboratories must generally use GC/MS methods for the determination of the VOC analytes. Gas chromatography with electron capture detection (GC/ECD) is an alternative method for the analyzing of PCBs.

\section{Metals}

Total metals analysis is a two-step process involving a sample preparation step followed by an analysis. Multiple preparation methods and analytical techniques may be required to complete the analysis for all metal target analytes.

Each site must decide, based on the nature of their waste stream, what preparation methods are appropriate for their wastes. Preparation methods from the Methods Manual and SW-846, are specified. Methods Manual includes required sample preparation procedure based on microwave-assisted hot acid digestion.

Cost and ALARA concerns drive the number of samples collected to the minimum necessary to meet program requirements. However, the effort to demonstrate representativeness both within and among waste containers provide a countervailing force in the direction of more samples and larger composites from containers.

\subsection{Waste Characterization Costs per 1,000 Drum Population}

The population of 1,000 drums chosen consists of 70 percent heterogeneous debris type wastes and 30 percent sludges. The sludges are further subdivided into 80 percent inorganic sludge wastes and 20 percent organic sludge wastes. Table 5-1 shows the unit costs of the waste characterization elements as well as the extended costs for the illustrative 1,000-drum population. The costs shown in this table are based on a fully operational, waste characterization line designed to process 4,000 drums per year. The costs are derived from the cost data generated as part of the INEEL planning to meet the requirements of the settlement agreement with the state of Idaho.

All drums in the subject population are examined by radiography to confirm waste stream identification and to look for nonconforming items.

All drums in the subject population are assayed for TRU radionuclides and uranium by NDA. PAN assay is used for 100 percent of the drums. In addition, 10 percent of the drums are also analyzed by high-resolution GS to determine the relative abundance of the individual radionuclides. Data validation is shown as a separate activity and includes radiography, PAN assay, and GS. 
All drums will be processed in the drum venting facility. At this point, 100 percent of the drums will be vented, and the headspace of the drum will be analyzed for hydrogen, methane, and the listed VOC target analytes. Under the proposed waste characterization program, these analyses will be performed at-line by diverting a portion of the headspace gases to an FTIR spectroscopy system and on-line analyzer for hydrogen. The cost listed for this element includes the drum venting activity, on-line analyses, and insertion of the drum vent filter. On each day of operation, a headspace gas sample will be pulled in a SUMMA7 canister as a quality control sample. This sample will be forwarded to the laboratory for analysis for hydrogen, methare, and VOCs by GC and GC/MS methods prescribed in the QAPP. The drum venting facility is expected to process 80 drums/day for each operational day. Headspace gas analysis QC samples will therefore be pulled for one in 80 drums (1.25 percent).

Additional characterization will be performed on 10 percent of the drums at a separate waste characterization facility. The cost of transporting the drums to this facility (e.g., from the INEEL Radioactive Waste Management Complex to Argonne National Laboratory - West) is shown as a separate cost item in Table 5- 1 applying to 10 percent of the waste drums. Only visual inspection will be performed on the 10 percent (i.e., 70 drums) of the heterogeneous waste drums to be examined.

The 10 percent of the sludge clrums to be subjected to detailed examination will be sampled for chemical analysis by coring. One core per drum will be removed. Of the 240 inorganic sludge drums, 24 will be cored. Two subsamples will be taken from each core for analysis for VOCs. A composite of the balance of the core will be subsampled for SVOCs, metals, and radioactivity screening. Each inorganic sludge drum will therefore require two VOC analyses and one each of SVOC, metals, and radioactivity screening parameters. Of the 60 inorganic sludge drums, six will be cored. These cores will get the same analytical suite as the in organic sludge drums except that the core composite will also be subsampled and analyzed for $P C B$ s.

Finally, Table 5-1 includes entries for the data validation activities required by the WIPP QAPP. The cost to process 1,000 drums of a representative waste distribution of the type described on a fully operational waste characterization processing line is $\$ 1,755,000$. 
Table 5-1 Costs for WIPP WAC Waste Characterization

\begin{tabular}{|c|c|c|c|c|c|c|c|c|c|}
\hline Analysis & Notes & Unit cost & $\begin{array}{c}\text { Percent } \\
\text { Required }\end{array}$ & Basis & $\begin{array}{l}\text { Basis } \\
\text { Factor }\end{array}$ & $\begin{array}{l}\text { Calculated } \\
\text { No. of } \\
\text { Drums }\end{array}$ & $\begin{array}{c}\text { Rounded } \\
\text { No. of } \\
\text { Drums }\end{array}$ & $\begin{array}{c}\text { Cost for } \\
1,000 \text { Drums }\end{array}$ & $\begin{array}{c}\text { Rounded to } \\
\text { Nearest } \$ 1000\end{array}$ \\
\hline Venting \& Headspace VOCs \& $\mathrm{H}_{2}$ & 1 & $\$ 80$ & 100 & All & 1 & 1000 & 1000 & $\$ 80,000$ & $\$ 80,000$ \\
\hline Headspace QC (VOCs \& $\mathrm{H}_{2}$ ) & 2 & $\$ 1,100$ & 1.25 & All & 1 & 13 & 13 & $\$ 14,300$ & $\$ 14,000$ \\
\hline Radiography & & $\$ 44$ & 100 & All & 1 & 1000 & 1000 & $\$ 44,000$ & $\$ 44,000$ \\
\hline Passive-Active Neutron & & $\$ 44$ & 100 & All & 1 & 1000 & 1000 & $\$ 44,000$ & $\$ 44,000$ \\
\hline Gamma Spectrometry & & $\$ 198$ & 10 & All & 1 & 100 & 100 & $\$ 19,800$ & $\$ 20,000$ \\
\hline Data Validation & & $\$ 64$ & 100 & All & 1 & 1000 & 1000 & $\$ 64,000$ & $\$ 64,000$ \\
\hline Visual Inspection & & $\$ 12,000$ & 10 & Debris & 0.7 & 70 & 70 & $\$ 840,000$ & $\$ 840,000$ \\
\hline Sample Coring & & $\$ 12,000$ & 10 & All Sludge & 0.3 & 30 & 30 & $\$ 360,000$ & $\$ 360,000$ \\
\hline Chemistry Suite & 3 & $\$ 4,600$ & 10 & Inorganic Sludge & 0.24 & 24 & 24 & $\$ 110,400$ & $\$ 110,000$ \\
\hline Chemistry Suite + PCBs & 3 & $\$ 6,350$ & 10 & Organic Sludge & 0.06 & 6 & 6 & $\$ 38,100$ & $\$ 38,000$ \\
\hline Detailed Debris Validation & 4 & $\$ 700$ & 10 & Debris & 0.7 & 70 & 70 & $\$ 49,000$ & $\$ 49,000$ \\
\hline Detailed sludge Validation & 5 & $\$ 900$ & 10 & Sludge & 0.3 & 30 & 30 & $\$ 27,000$ & $\$ 27,000$ \\
\hline Production Validation & 6 & $\$ 72$ & 90 & All & 1 & 900 & 900 & $\$ 64,800$ & $\$ 65,000$ \\
\hline Total & & & & & & & & $\$ 1,755,400$ & $\$ 1,755,000$ \\
\hline
\end{tabular}

1. Includes routine analysis of headspace gases for VOCs and hydrogen .

2. Quality control analyses of headspace gas analysis by sample collection and analysis by GC and GC/MS.

3. Chemistry suite includes VOCs, SVOCs, total metals.

4. Applicable to data collected on drums subjected to visual inspection.

5. Applicable to data collected on drums sampled by coring for chemical analysis.

6. Applicable to data collected on drums not subjected to examination by visual inspection or sampled by coring. 


\section{Summary and Conclusions}

\subsection{Comparison of Costs of Characterization and Monitoring}

This document estimates cost of characterizing mixed wastes, including front-end waste characterization, monitoring systems, emission controls, and final waste form characterization for several treatment scenarios. Table 6-1 summarizes the costs of the various scenarios assessed in this report. Keep in mind that these costs are only those associated with characterization and monitoring requirements for 1,000 hypothetical drums of alpha-mixed waste. Costs would increase for processing of additional drums, although some costs (such as that of purchasing necessary monitors), would remain fixed as greater numbers of drums are processed.

Costs for characterization for non-thermal treatment are more than for thermal treatment because of the additional characterization costs associated with multiple process steps, and because of the increased number of drums generated through the non-thermal treatment process. Compared to the thermal base case, costs of front end and final waste form characterization under the 'improved' configuration are less while costs of off gas monitoring and analysis are higher.

Note that the WIPP case should not be compared directly to the cases involving treatment in terms of whether WIPP is ultimately more cost-effective. WIPP costs reflect only costs to characterize waste for compliance with WIPP Waste Acceptance Criteria (WAC) prior to disposal. Costs to characterize waste for any treatment required in order to meet the WIPP WAC are not included.

Table 6-1 Costs for Characterization and Monitoring Scenarios evaluated in this study

\begin{tabular}{|l|r|r|r|r|r|}
\hline & $\begin{array}{c}\text { Front End } \\
\text { Characterization }\end{array}$ & $\begin{array}{c}\text { Process } \\
\text { Monitoring \& } \\
\text { Off gas Control }\end{array}$ & $\begin{array}{c}\text { Off gas } \\
\text { Monitoring } \\
\text { \& Analysis }\end{array}$ & $\begin{array}{c}\text { Characterization } \\
\text { of Final Waste } \\
\text { Form }\end{array}$ & $\begin{array}{c}\text { Total to } \\
\text { Nearest } \\
\$ 1000\end{array}$ \\
\hline Thermal Base Case & $\$ 2,387,000$ & $\$ 56,000$ & $\$ 125,000$ & $\$ 1,755,000$ & $\$ 4,323,000$ \\
\hline Non-Thermal System & $\$ 12,626,000$ & $\$ 56,000$ & $\$ 125,000$ & $\$ 3,421,000$ & $\$ 16,228,000$ \\
\hline Improved Configuration & $\$ 1,896,000$ & $\$ 56,000$ & $\$ 208,000$ & $\$ 556,000$ & $\$ 2,716,000$ \\
\hline WIPP & $\$ 1,755,000$ & N/A & N/A & N/A & $\$ 1,755,000$ \\
\hline
\end{tabular}

The area of greatest cost reduction under the improved configuration is for final waste form characterization, where costs are reduced by 70 percent due to volume reduction achieved through treatment and due to elimination of sampling and analysis for those WIPP WAC requirements which would not apply to a treated waste form. Costs of front end characterization under the improved configuration are reduced by 20 percent due to use of remote techniques, process and off gas controls, and continuous emission monitors. This amount of savings can be significant given the number of drums to be processed. However, the costs of opening a drum to conduct sampling and analysis contribute to the greatest portion of the costs of characterization under any of the scenarios. 


\subsection{Opportunities for Cost-Effective Improvements in Characterization and Monitoring}

The greatest opportunity for cost savings under each of the scenarios lies in reducing the number of drums to be opened for sampling and analysis. This opportunity can only be realized through a strategy which provides process certainty for every waste parameter of concern. For example, development of non-intrusive techniques for sampling for metals solves one of the characterization issues. If drums must still be opened for other purposes, then the real cost savings cannot be achieved. Best results would be achieved through pursuit of a cohesive strategy which relies upon non-intrusive sampling and assay for radionuclides and metals, combined with methods for assuring that organics are within acceptable ranges. This approach would be coupled with a means of evaluating the data received to determine the amount of sampling needed as certainty is or is not established. This overall strategy would allow for reduction of sampling and analysis costs over the long term as process operations and waste streams are better understood. For example, the percentage of characterization could be reduced from ten percent to five percent or even one percent. Other cost reductions could be achieved as alternative techniques can be substituted for current labcratory analytical methods.

Although development work and discussions with the regulatory community must be continued to realize cost savings, improvements have the potential to address those unique aspects of mixed waste that create difficulties when applying standard characterization methods. Nonintrusive methods or continuous monitoring can reduce workel: exposure and can substitute for intrusive waste sampling and laboratory analysis. Finally, the characterization needs for a particular management approach can be tailored to that approach and continually reviewed to determine how the desired performance objectives can be met most efficiently.

\subsection{Conclusions and Recommendations for Further Action}

To fully assess the cost differences between treatment alternatives, all relative costs should be considered. Life-cycle costs. estimates have not been prepared for the scenarios described in this report, therefore specific recommendations regarding the most cost-effective scenario is not possible at this time. However, this study resulted in the following conclusions regarding the relative mixed waste characterization costs and reciommendations for further action.

Of the four components of waste characterization, reducing front-end waste characterization represents the greatest opportunity for ccist saving. Technology development in the areas of treatment, monitoring systems, nondestructive waste characterization techniques, and emission controls present opportunities to reduce front-end waste characterization requirements. Additional studies associated with mixed waste characterization will result in additional technical feasibility and cost information to update this report.

The costs of off gas monitorirg and analysis are relatively low for all treatment scenarios. The proposed combustion standards for hazardous waste incinerators provide an opportunity to minimize front-end characterization by utilizing state-of-the-art pollution controls and monitoring devices. If the necessary sensitivity, accuracy, and performance requirements for continuous emissions monitoring systems can be achieved, these technologies offer significant potential for overall characterization cost savings. Federal and state regulations regarding emissions monitoring are being considered in light of overall waste 
characterization and treatment standards. Therefore, from both a cost and a regulatory compliance standpoint, development efforts in this area are warranted.

In all cases, reductions in front-end characterization depend on proven CEMs capable of detecting low concentrations of chemical and radionuclide emissions established under applicable regulations.

Decreasing front-end waste characterization costs for rotary kiln incineration depends on gaining a better understanding of the treatment system operations for alpha mixed waste and the successful

demonstration of the off gas process. Testing and proof of operations of robust systems can minimize issues related to obtaining a representative sample of heterogeneous waste.

To achieve expected costs savings from treatment of waste prior to disposal at WIPP, the WIPP WAC should be reviewed to determine whether changes are needed to address a treated waste form.

The most significant cost associated with WIPP TRU waste characterization requirements is for visual examination. Development of radiographic techniques to substitute for visual examination can provide cost savings as well as reduced potential worker and environmental exposures.

This study also raises an issue that may impact DOE's success in achieving cost-effective treatment of alpha-mixed waste. The DOE has invested significant effort in establishing nonintrusive methods of radioactive assay of alpha-mixed waste, and should continue to invest similar resources to establish nonintrusive methods of characterizing chemical, physical, and hazardous properties of alpha-mixed waste. Even though the requirements appear to be shifting to accommodate a systems approach to characterization and monitoring where various steps of the treatment process contribute to assurance of compliance with requirements for emissions and final waste form, a certain amount of waste analysis will be required to verify that wastes being fed into a system fit within its operating envelope. To obtain a permit to treat hazardous waste, compliance with RCRA's hazardous waste analysis requirements will be critical. 


\section{References}

Battleson, D., C. Whitworth, and K. Filius, 1994, Latest Minimum Additive Waste Stabilization and Buried Waste Integrated Demonstration Test Results on the Plasma Centrifugal Furnace, 1994 International Incineration Conference, Houston, TX., May 9-13.

Cornelison, C., L. M. DeWitt, G. R. Hassel, and G. L. Leatherman, 1995, Final Report for the Advanced Analytical Instrumentation Demonstration, SAIC Report No. SAIC-95/1308, October.

Dalton, J. D., R. L. Gillins, T. L. Harris, and A. L. Wollerman, 1992, An Assessment of Off gas Treatment Technologies for Application to Thermal Treatment of Department of Energy Wastes, DOE/MWIP-1, September.

Eddy, T. L., B. D. Raivo, N. R. Soelberg, and O. Wiersholm, 1995, Advanced Mixed Waste Treatment Project Melter System Preliminary Design Technical Review Meeting, INEL-995/0054, Rev. 1, June.

EERC (Energy and Environmental Research Corporation), 1997, Technical Resource Document: Mixed Waste Characterization for Thermal Treatment Systems, sponsored through an Interagency Agreement between EPA and DOE, April 1997.

EG\&G Idaho, 1992, Mixed and Low-Level Waste Treatment Facility Project, Volume 3, EGG-PD-92006, April.

EPA, 1993, Characterizing Containerized Mixed Low-Level Waste for Treatment, EPA/600/R-94/149, Office of Research and Development, Washington, D.C., May.

Feizollahi, F., W. J. Quapp, H. J. Hempill, and F. J. Groffie, 1994, Integrated Thermal Treatment System Study-Phase 1 Results, EGG-MS-1211, July.

Feizollahi, F. and W. J. Quapp, 199.5, Integrated Thermal Treatment Systems Study - Phase 2 Results, INEL-95/0129, August.

French, N. B., J. D. Dalton, J. Vavruska, and Second Stage Destruction and Off gas Treatment Technical Support Group, 1994, Technical Area Status Report for Second-Stage Destruction and Off gas Treatment, DOE/MWIP-5, August.

Geimer, R., T. Hertzler, R. Gillins, and G. L. Anderson, 1992, Assessment of Incineration and Melting Technologies for RWMC Buried Waste, EGG-WTD-10035, February.

Hassel, G. R., et al, 1994, Evaluation of the Test Results from the Plasma Hearth Process Mixed Waste Treatment Applications Demonstration, SAIC-94/1095, October.

INEL, 1995, Mixed Waste Focus Area Integrated Technical Baseline Report Phase 1 (Draft), December.

Maraj, R., 1994, Review of Off Gas System Designs for Plasma and Vitrification, BDM Federal, Inc, December. 
Mayberry, J. L., W. J. Quapp, F. Feizollahi, J. C. Del Signore, and J. McFee, 1991, Preliminary Systems Design Study Assessment Report, EGG-WTD-9594, EG\&G Idaho, Inc., June.

Roesener, W. S., N. R. Soelberg and A. L. Ayers, 1992, "Preconceptual Design Process Evaluation for the Idaho Waste Processing Facility Project", EGG-WMO-10385, August.

Waste Management Facilitie: Cost Information for Mixed Low Level Waste, INEL-95/0014.

Shropshire, David E., Sherick, Michael J., and Biagi, Waste Management Facilities Cost Information for Transuranic Waste, INEL-S15/0015, June 1995.

Soelberg, N. R., A. G. Chambers, G. L. Anderson, L. L. Oden, W. K. O'Connor, and P. C. Turner, 1994, Arc Melter Demonstration Baseline Test Results, EGG-WTD-11138, July.

Soelberg, N. R., A. G. Chambers, G. L. Anderson, W. K. O'Connor, L. L. Oden, and P. C. Turner, 1996, Graphite Electrode Arc Mel'ter Demonstration Phase 2 Test Results, INEL-95/0502, April.

Surma, J. E., et al, 1993, Evaiuation of the Graphite Electrode DC Arc Furnace for the Treatment of INEL Buried Wastes, PNL-13525, UC-602, June.

F. A. Seiler, G. J. Newton, and R. A. Guilmette, "Continuous Monitoring for Airborne $\alpha$ Emitters In a Dusty Environment, " Healtłı Physics, 54 (1988) 503.

Alpha-Beta Particulate Monitor LB 150 D, Berthold Analytical Instruments, Nashua, NH.

C. V. McIsaac, R. J. Gehrke, C. W. Sill, "Rapid Transuranic Monitoring Laboratory Final Report, Volume 1: Progress Report on ${ }^{90} \mathrm{Sr} / 238 \mathrm{U}$ Analyzer and Alpha Continuous Air Monitor" LITCO Internal Report No. INEL-95-207, Llecember 1994.

P. A. Steadman, J. D. Johnson, K. S. Allander, J. A. Bounds, J. P. Johnson, J. E. Koster, D. W. MacArthur, "A Portable Sample Monitor for Low-Level Alpha Contamination," Proceeding of Waste Management '95 Conferencis.

Eberline PING/SPING radiation monitor, Eberline Instrument Corporation, Santa Fe, NM.

L. D. Koeppen, and J. W. Rogrers, "Status Report of the ATR SPING-3A And Detailed Calibration Guideline," DOE Report ECi\&G-CS-7126, December 1985.

Section 5.3.1, "Statistical Sanmpling Strategy," QAPP,

DOE, 1996, Guidance for Preparing Transuranic Waste Sampling Plans, 


\section{Appendix A}

\section{Regulatory Requirements for Mixed Waste}

Thermal Treatment 
A-1. Current requirements for thermal treatment - the Clean Air Act and the Resource Conservation and Recovery Act.

Operation of thermal treatment units is regulated under the Clean Air Act (CAA) and RCRA. The CAA has New Source Performance Standards (NSPS) provisions directed at incinerators; these include facilities defined as any furnace in the process of burning solid waste for the purpose of reducing the volume of waste by removing; combustible matter. Under 40 CFR $\$ 60$ Subpart $E$, a particulate matter standard for incinerators with charging rates of more than 45 metric tons/day has been established. Per Subpart $\mathrm{E}$, on and after the date on which the performance test required by 40 CFR $\S 60.8$ is completed, the facility is not to discharge any gases containing particulate matter in excess of $0.18 \mathrm{~g} / \mathrm{dscm}(0.08$ $\mathrm{gr} / \mathrm{dscf})$ corrected to 12 percent carbon dioxide $\left(\mathrm{CO}_{2}\right)$. To implement the CAA, most states have a preconstruction permit program (permit to construct (PTC)). in place to govern emissions of both major and minor sources of criteria pollutants (sulfur oxides, nitrogen oxides, ozone, carbon monoxide, particulate, total hydrocarbons and level). Many states also have their own air toxics control programs which may require a source to add controls or to obtain a PTC. Major sources are also subject to the CAA operating permit program and must pay permit fees and submit a permit to operate application to the state or EPA.

Mixed waste units on DOE sites are subject to compliance with the NESHAPs standard for radionuclide emissions from DOE facilitates. Sources with potential dose over .1 millirem effective dose equivalent must submit an application fcr approval to construct from EPA. The NESHAPs standard also includes monitoring requirements for sources, including periodic monitoring requirements for small sources.

RCRA requires operating uni s to obtain Part B permits to operate. Subpart O of the RCRA regulations, 40 CFR 261.343, establishes the following performance standards for incinerators:

For incinerators, Subpart $\mathrm{O}(\$ 261.343)$ requires a unit to meet the following performance standards:

A destruction and removal efficiency (DRE) of 99.99 percent for each designated principle organic hazardous constituent (POHC) for each waste feed;

A DRE of 99.9999 percent for each designated POHC for each waste feed for units burning FO20, FO21, FO22, FO23, FO26, or FO27 (dioxin listed) wastes;

A hydrogen chloride $(\mathrm{HCl})$ emissions rate no greater than the larger of either $1.8 \mathrm{~kg} / \mathrm{hr}$ or 1 percent of the HCL in the stack gas prior to entering any air pollution control equipment;

A particulate matter (PM) emission rate of no more than $180 \mathrm{mg} / \mathrm{dscm}$ corrected to 7 percent oxygen.

In addition, operating requirements will be set on a case by case basis as part of a facility's permit conditions. Parameters for which limits will be set include carbon monoxide (CO) level in the stack gas, waste feed rate, combustion temperature, an appropriate indicator for combustion gas velocity, and any other parameters as necessary to ensure the performance standards are met. In addition, as part of the permit conditions, the allowable variations in incinerator system design or operating procedures will be defined. Other operating requirements that will be set include:

Nonallowance of waste feed during start-up or shut down unless the unit is operating within permit conditions; 
Keeping the combustion zone sealed and maintaining a combustion zone pressure lower than atmospheric to control fugitive emissions;

Use of an automatic waste feed cutoff when condition deviate from permit limits;

Cease of operation when changes in waste feed, incinerator design or operating conditions exceed designated limits.

Requirements for incinerators specific to waste characterization can be found in 40 CFR $\$ 264.341$ and $\S$ 265.341. Waste analysis results may be required to be submitted at various points along the permit process. A waste analysis may be required:

initially to classify the waste and determine if any exemptions apply;

with submittal of a Part B application;

as part of a submitted trial burn plan;

as part of the documentation to show the use of data from a similar facility in lieu of a trial burn; or throughout normal operation to verify that the waste feed is within permit conditions.

The type and level of waste characterization will depend upon which of these five purposes is the objective of the analysis. The remainder of this section describes waste analysis requirements at different points along the permit process.

New and existing incinerators, under 40 CFR $\S 264.341$, are required to submit a waste analysis as part of the trial burn plan or the Part B application. The analysis of the waste feed must be sufficient to provide the information required to document any requested exemptions ( $40 \mathrm{CFR} \S 270.19)$ or as required by the trail burn plan ( $40 \mathrm{CFR} \S 270.62(\mathrm{~b})$ ). In addition, throughout normal operation, an owner/operator must conduct sufficient waste analysis to verify that the waste feed to the incinerator is within the physical and chemical composition limits specified in the permit (40 CFR $\S 264.341(\mathrm{~b})$ ).

New standards have recently been imposed for incinerator emissions and are discussed below. However, until proposal of these new standards, the RCRA standards for boilers and industrial furnaces (BIF) were often used as an additional basis for emission standards in RCRA permits for incinerators. For BIFs, Subpart $\mathrm{H}$ requires a unit to meet the following performance standards:

A destruction and removal efficiency (DRE) of 99.99 percent for each designated principle organic hazardous constituent (POHC) for each waste feed;

A DRE of 99.9999 percent for each designated POHC for each waste feed for units burning FO20, FO21, FO22, FO23, FO26 or FO27 (dioxin-listed) wastes;

A emission rate of listed metals no greater than specified levels or resulting in a risk greater than $1 \times 10-6$ to the surrounding population; 
An $\mathrm{HCl}$ emission rate no greater than specified levels or resulting in a risk greater than $1 \times 10-6$ to the surrounding population;

A particulate matter em:ssion rate of no more than $180 \mathrm{mg} / \mathrm{dscm}$ corrected to 7 percent oxygen;

A CO emission rate no greater than 100 ppmv or at a level established during the trial burn when the unit is operating at a hydrocarbon ( $\mathrm{HC}$ ) emission rate of no greater than $20 \mathrm{ppmv}$.

Waste analysis results for BIF's may be required to be submitted at many of the points along the permit process similar to the required of incinerators. For example, waste characterization may be required:

initially to classify the waste and determine if any exemptions apply;

with submittal of a Part B application;

as part of a trial burn pleın;

as part of the documentation to show the use of data from a similar facility in lieu of a trial burn; or throughout normal operation to verify that the waste feed is within permit conditions.

The type and level of waste claracterization will depend upon the object of the analysis. The remainder of this section discusses waste characterization requirements for BIFs at different points along the permit process.

Waste analysis requirements for BIF can be found under 40 CFR Subpart H $\S 266.102$. Boilers and industrial furnaces must perform waste analysis to quantify the concentration of any constituent from Appendix VIII of 40 CFR $\S 251$ that may "reasonably be expected to be in the waste." Any Appendix VIII constituents excluded frcm the analysis must be identified and the reason for their exclusion explained. The analysis must be sufficient to allow use by the permit writer to "prescribe such permit conditions as necessary to protect human health and environment." In addition, the analysis must be adequate to provide the information required to document any required by the trial burn $(\$ 270.66)$. The information is submitted with Part B of the permit application. For facilities operating under interim status, the information is subnitted as a portion of the trial burn plan required by 40 CFR $\S 270.66(\mathrm{~g})$. In addition, BIFs must conduct waste analysis during normal operations to "ensure that the hazardous waste, other fuels, and industrial furnace feedstocks fired into the boiler or industrial furnace are within the physical and chemical conposition limits specified in the permit" (40 CFR $\S 266.102$ (B)).

\section{A-2. Toxic Substance Contrcl Act (TSCA) requirements}

Units that process $\mathrm{PCB}$ waste; must also comply with TSCA requirements. TSCA performance standards call for a 2 second clwell time at $1200 \mathrm{C}$ and 3 percent excess oxygen $\left(\mathrm{O}_{2}\right)$ or a 1.5 second dwell time at $1600 \mathrm{C}$ and 2 percent excess $0_{2}$ while burning any PCB contaminated liquids. When burning PCB contaminated solids, the mass air emissions from the incinerator are limited to $0.001 \mathrm{~g} \mathrm{PCB}$ per $\mathrm{kg}$ of $\mathrm{PCB}$ introduced intc the incinerator. Combustion efficiency when burning either liquid or solid PCB contaminated waste must be at least 99.99 percent. The rate and quantity of PCBs fed to the system must be measured and recorded at intervals no longer than 15 minutes. Various stack gas parameters such as $\mathrm{CO}, \mathrm{O}_{2}, \mathrm{PM}$ and oxides of nitrogen (NOx) must also be monitored. An additional requirement 
calls for the use of water scrubber for $\mathrm{HCl}$ control during PCB incineration. A waiver for this and other requirements specified under Part $\S 761.71$ (a) and (b) can be sought by a proposed facility. Evidence must be submitted that the operation of the incinerator will not present an unreasonable risk of injury to health or the environment from PCBs. On the basis of such evidence and any other information, EPA at their discretion may waive the requirement.

A separate TSCA permit may be required, and EPA is responsible for TSCA permits. However, many EPA regions seek to streamline the TSCA permit process by treating the TSCA permit application as providing only the information required by TSCA and not already addressed in the RCRA permit application.

\section{A-3. Emerging requirements for incinerators}

Under the Clean Air Act (CAA) Amendments of 1990, EPA is directed to establish maximum achievable control technology (MACT) for all new and existing major sources of hazardous air pollutants (HAP) emissions. A major source is defined as a stationary source that emits, or has the potential to emit considering controls, 10 tons per year of a HAP or 25 tons per year of a combination of HAPs. An area source is generally a stationary source that is not a major source. EPA published an initial list of 174 categories of such major and area sources in July of 1992.

Hazardous waste incinerators is one of the 174 categories of sources listed. The listing was based on EPA's determination that at least one hazardous waste incinerator may reasonably be anticipated to emit several of the 189 listed HAPs in quantities sufficient to designate them as major sources. On April 19, 1996, EPA issued a proposed rule entitled "Revised Standards for Hazardous Waste Combustors", 61 FR 17358 , that proposes to regulate HAP emissions from hazardous waste incinerators based on MACT. On May 2, 1997, revised standards were proposed in the form of a Notice of Data Availability (NODA), 61 FR 2412. These rules are intended to apply to new units constructed after the date of the proposed rule and to existing units within three years of finalization of the rule. These proposed rules are unique from two aspects. First, EPA proposes to apply the rules to all hazardous waste incinerators whether the incinerator would be considered a major source of HAPs or not. Second, the rules will be applied through both the CAA and RCRA; however, the specific means for permitting incinerators has not been proposed.

The proposed rules, as changed by the NODA, would set the following emission limits and monitoring requirements:

- Dioxins and furans have a limit for existing and new sources of $0.20 \mathrm{ng} / \mathrm{dcm}$. Monitoring requirements are set for batch limits and to maintain the maximum temperature inlet to dry PM control, the maximum combustion chamber temperature, the maximum flue gas flowrate, and the maximum hazardous waste feed rate.

- Mercury limits for existing and new sources must not exceed 40 microgr/dscm for each 10 -hour rolling average. CEMs will be used unless it can be established that maximum feed rate of mercury could not result in exceeding the of emission standard.

- A limit for current sources of combined semivolatile lead and cadmium is $100 \mathrm{microgr} / \mathrm{dscm}$, per 12-hour rolling average (if CEMs are used). Monitoring requirements are composed of CEMs for 
multi-metals. If a CEM is not used, then limits are set for particulate matter, maximum feed rate for semivolatile metals, maximum total chlorine and chloride, and minimum gas flow rate.

- Combined low volatility arsenic, beryllium, and chromium metals have existing and new source limits set at $55 \mathrm{microgr} / \mathrm{dscm}$ per 10 -hour rolling average (if CEMs are used). Monitoring requirements are compcsed of CEMs for multi-metals. If a CEM is not used, then limits are set for particulate matter, maximum feed rate for low volatility metals, maximum total chlorine and chloride, and minimum gas flow rate.

- Carbon monoxide existing and new source limits are $100 \mathrm{ppm}$, dry for every rolling hour average. CEMs are to be used for: monitoring requirements.

- Existing and new source limits for hydrocarbons are $10 \mathrm{ppm}$, dry for every rolling hour average, and reported as propane. CEMs are to be used for monitoring requirements.

- Combined acid and chlorine gas (expressed as $\mathrm{HCl}$ equivalents) have existing and new source limits of $75 \mathrm{ppm}$, dry for every rolling hour average (if CEMs are used). Monitoring limits are composed of CEMs. If CEMs are not used, limits are set for chlorine/chloride feedrate, maximum flue gas flow production rate. Operating limits on control technologies used are also set if CEMs are not used.

- Particulate matter limits for existing and new sources are 0.015 grams/dscf over 2 hours rolling average. CEMs are to be used for monitoring requirements.

These proposed standards we:e established according to the CAA requirement that MACT standards must be at least as stringent as the minimum level of control specified in CAA Section 112(d)(3), often called the "MACT floor." In determining the MACT floor, EPA must look at the level of control currently achieved by existing sources in a given source category. For existing sources, the MACT floor must be no less stringent than the emission control achieved by the best performing 12 percent of sources in that category (or the top 5 performers where fewer than 30 sources exist within a category.) For new sources, the MACT floor is more stringent; it is set by the single, best-performing source in the category.

EPA can decide to select a control strategy more stringent than the MACT floor for both existing and new sources. Standards that are more stringent than the floor are called "beyond the floor" (BTF) standards. EPA can set BTF standards, but they have to consider criteria such as cost-effectiveness, energy, technologies currently in use within these industry sectors, other technologies that have been demonstrated and are available on the market, health benefits, and non-air environmental implications.

\section{A-4. Front end characterization requirements selected for cost evaluation in this study.}

In addition to the waste characterization requirements of RCRA, operating requirements for the thermal treatment unit drive characterization information needs. This study documents costs for characterization required for safe and compliant operation of treatment systems. Table A-1 provides a listing of the waste analysis parameters and rationale for their selection. 
Table A-1. Rationale for selection of waste analysis parameters for incinerator candidate waste.

\begin{tabular}{|c|c|c|c|c|c|}
\hline \multirow[b]{2}{*}{ Parameter } & \multicolumn{4}{|c|}{ Waste Matrix } & \multirow[b]{2}{*}{ Rationale } \\
\hline & $\begin{array}{l}\text { Homo- } \\
\text { geneous } \\
\text { Solids }\end{array}$ & $\begin{array}{l}\text { Wet } \\
\text { Solids }\end{array}$ & $\begin{array}{l}\text { Aqueous } \\
\text { Liquid }\end{array}$ & $\begin{array}{l}\text { Organic } \\
\text { Liquids }\end{array}$ & \\
\hline $\begin{array}{l}\mathrm{pH} \text {, alkalinity, or } \\
\text { acidity }\end{array}$ & & & $\mathrm{X}$ & & $\begin{array}{l}\text { Analyses needed for aqueous solutions to determine proper order handling and storage; } \\
\text { may also be characteristics of a particular process waste; therefore, used as a fingerprint } \\
\text { parameter. }\end{array}$ \\
\hline Specific anions/cations & & & $\mathrm{X}$ & & $\begin{array}{l}\text { These parameters may be run on aqueous samples to account for major constituent or } \\
\text { type of acid/base/salt present; wastes containing cyanide and sulfide must be measured } \\
\text { at the ppm level because there are possible toxic effects to be considered during } \\
\text { handling and storage or incineration. }\end{array}$ \\
\hline $\begin{array}{l}\text { Solids (total suspended } \\
\text { solids and particle size } \\
\text { in liquids) }\end{array}$ & & & $\mathrm{X}$ & $\mathrm{X}$ & $\begin{array}{l}\text { Type and concentration of solids are important for aqueous and organic liquid samples } \\
\text { to determine incineration and pumping/handling characteristics: significant changes in } \\
\text { solid concentration may reflect a change in the waste chemical composition. }\end{array}$ \\
\hline Selected organics & $\mathrm{X}$ & $X$ & $\mathrm{X}$ & $X$ & $\begin{array}{l}\text { Based on data supplied by the generator, major organic compound components, } \\
\text { hazardous constituents, or priority pollutants may be selected for analysis to verify } \\
\text { waste characteristics. }\end{array}$ \\
\hline Flash point & & & & $\mathrm{X}$ & $\begin{array}{l}\text { Knowledge of this parameter helps to ensure safe handling and storage of a waste; } \\
\text { changes, especially towards lower temperature values, must be known to avoid a } \\
\text { potential fire/explosion hazard. }\end{array}$ \\
\hline Heavy metals & $\mathrm{X}$ & $\mathrm{X}$ & $\mathrm{X}$ & $\mathrm{X}$ & $\begin{array}{l}\text { Levels of heavy metals, particularly Appendix VIII metals, in a waste need to be known } \\
\text { to ensure losses to the environment are properly managed. }\end{array}$ \\
\hline Specific gravity & & & $\mathrm{X}$ & $\mathrm{X}$ & $\begin{array}{l}\text { Specific gravity value is important in calculations to provide a material balance across a } \\
\text { treatment process and to give a true value of the amount of wastes being handled; } \\
\text { changes in the specific gravity definitely signal a change in the makeup of the waste. }\end{array}$ \\
\hline
\end{tabular}


Table A-1. (continued).

\begin{tabular}{|c|c|c|c|c|c|}
\hline \multirow[b]{2}{*}{ Parameter } & \multicolumn{4}{|c|}{ Waste Matrix } & \\
\hline & $\begin{array}{l}\text { Homo- } \\
\text { geneous } \\
\text { Solids }\end{array}$ & $\begin{array}{c}\text { Wet } \\
\text { Solids }\end{array}$ & $\begin{array}{c}\text { Aqueous } \\
\text { Liquid }\end{array}$ & $\begin{array}{l}\text { Organic } \\
\text { Liquids }\end{array}$ & Rationale \\
\hline
\end{tabular}

Elemental analysis

(carbon, hydrogen, sulfur, nitrogen,

phosphorous, and organically bound halide)

\section{Ash content}

Heat of combustion

$\mathrm{X}$

$\mathrm{X}$

$\mathrm{X}$

X

Percent water

X $\mathrm{X}$

Viscosity

$\mathrm{X} \quad \mathrm{X} \quad \mathrm{X} \quad \mathrm{X}$

X $\quad$ X $\quad$ X

X

X $\quad \mathrm{X}$

Knowledge of these parameters is necessary for determination of the incineration system conditions, (i.e. computation of stoichiometric air requirements); when information on the chemical nature of waste is well defined, these parameters may not be required; changes in key parameters such as phosphorus, sulfur, and organic halide must be known so the adequacy of pollution control equipment can be confirmed.

Ash content is important for evaluating wastes for incineration to determine slag formation, assess particulate loading, and determine if the ash handling system is sufficient; changes in ash content may reflect significant changes in the inorganic constituents of the waste.

This parameter is needed for incineration candidates to determine heat load for proper incineration operation and to allow for auxiliary fuel usage as required; changes in Btu level of a waste reflect changes in the organic composition of the waste.

Water concentration will determine whether the waste should be treated as an aqueous waste; waste concentration can be used to determine storage (especially compatibility) and handling requirements, and provide material balance on solid wastes; changes in water content must be known to ensure adequate treatment.
Viscosity values will help determine the method of waste handling, blending, and storage; very viscous wastes may require heating, special pumps or nozzles; changes in viscosity may affect the nozzle spray characteristics, and handling and storage requirements; important in calculating feed rates. 
Table A-1. (continued).

\begin{tabular}{cccc}
\hline & \multicolumn{3}{c}{ Waste Matrix } \\
\cline { 2 - 4 } & Homo- & & \\
Parameter & Seneous & Wet Aqueous & Organic \\
\hline
\end{tabular}

Only organically bound halides disassociate significantly during incineration. The Guidance Manual for Hazardous Waste Incineration Permits states that measurement of organically bound chloride is to evaluate potential emissions of hydrogen chloride. In addition, salts of halides have not been detected in the wastes analyzed as candidates for incineration. 
A-5. Disposal characterization requirements.

This study evaluated two scenarios for disposal - at WIPP and at a subtitle C land disposal facility. The requirements for WIPP are detailed in the section on WIPP and focus on obtaining sufficient information for both transportation, compliance with the disposal WAC and compliance with the EPA requirements for performance of radioactive waste disposal facilities. Section 5 of this document contains the requirements for WIPP. Detailed below are the characterization requirements related to RCRA Subtitle C disposal.

Under 40 CFR $\$ 268$, certain waste types are restricted from direct land disposal. Specific groups of wastes are banned from landjill disposal as of an identified effective date. Subpart B of 40 CFR $\$ 268$ provides a schedule for land disposal prohibition for four different waste groups. While such wastes are prohibited from direct landfill disposal, limited circumstances under which these wastes may continued to be land disposed have been defined. These circumstances are defined as when a waste (or residue) meets appropriated treatment standards. As specified in 40 CFR $\S 268$ Subpart D, a restricted waste may be landfilled only if an extract or residue of the waste does not exceed a specified concentration for any listed hazardous constituent or only after the restricted waste has been treated by a specified treatment technology. Support $\mathrm{D}$ provides a listing of hazardous constituents and associated allowable concentrations as well as a listing of acceptable treatment technologies for various types of wastes.

Generators of wastes have the responsibility of determining the EPA Hazardous Waste Number applicable to each waste in order to determine the appropriate treatment standard under $\S 268$ Subpart D. Generators must use the Toxicity Characteristic Leaching Procedure (TCLP) or the extraction Procedure Toxicity (EP) test or use knowledge of the waste to make this determination. LDR requirements for characterization of wastes at reatment facilities include:

For waste with treatment standards expressed as concentrations in the waste or waste extract, the treatment residues must be tested to ensure the residue of extract meets the applicable treatment standards.

For wastes that are prohibited under 40 CFR $\$ 268.32$ (those waste defined as California listed wastes) but not subject to any treatment standard, the treatment residue must be tested to assure that the treatment residues comply with applicable prohibitions. California listed wastes are those which are liquid with a low pH, contain PCBs or are primarily water with halogenated compounds. These wastes are prohibited from land disposal. Therefore, a waste should be treated to remove all California liquids prior to landfill disposal.

For characteristic wastes, if the waste war one classified by EPA waste code D002 or D012 through D043 at the point of generation, the residue must be analyzed for underling hazardous constituents, as defined in 40 CFR 268.2, that can reasonably be expected to have been present in the waste at the point of generation (40 CFR 268.7(a)).

The testing of residues must kie conducted according to the frequency specified in the facility's waste analysis plan. 
Appendix B

Summary of Analytical Procedures for Characterization/Monitoring Requirements 


\section{Appendix B}

Summary of Analytical Procedures for Characterization/Monitoring Requirements

\begin{tabular}{|c|c|c|c|}
\hline Analysis & Preparation Method & Analytical Method & $\begin{array}{c}\text { Cost per Sample } \\
\text { (remote) }\end{array}$ \\
\hline Ignitability & - & SW846- 1011 & $\$ 100$ \\
\hline Corrosivity & - & SW846 - 1011 & $\$ 46$ \\
\hline Reactivity & - & SW846 II 7.3 & $\$ 2,700$ \\
\hline Organics & SW846 - 1311, 3050, \& 3500 series & SW846 - $6010,7470, \& 8000$ series & $\$ 1,021$ \\
\hline TSCA/PCB & $\begin{array}{l}\text { SW846 - } 3500 \text { series } \\
\text { Laboratory SOPs }\end{array}$ & $\begin{array}{l}\text { SW846 - } 8080 \text { or } 8081 \\
\text { Laboratory SOPs }\end{array}$ & $\$ 275$ \\
\hline $\begin{array}{l}\text { Radionuclides } \\
\text { Gamma Spectroscopy } \\
\text { Gross Alpha } \\
\text { Gross Beta }\end{array}$ & & & $\begin{array}{l}\$ 338 \\
\$ 338 \\
\$ 338\end{array}$ \\
\hline $\begin{array}{l}\text { Trial Burn Appendix VIII } \\
\text { POHC selection }\end{array}$ & SW846 - 3500 series & SW846 - 8000 series & $\$ 13,500$ \\
\hline Metals & SW846 - 3050 & SW846 - 6010 and 7470 & $\$ 366$ \\
\hline Chloride & SW846 - 5050 & SW846 - 9056 & $\$ 137$ \\
\hline BTU & - & ASTM D3286-91a & $\$ 3,240$ \\
\hline Viscosity & - & ASTM D445-88 & $\$ 165$ \\
\hline Chemistry Suite & SW846 - 1311, 3050, \& 3500 series & SW846 - $6010,7470, \& 8000$ series & $\$ 4,600$ \\
\hline $\begin{array}{l}\text { Chemistry Suite plus } \\
\text { PCBs }\end{array}$ & SW846 - $3050 \& 3500$ series & SW846 - $6000,7000, \& 8000$ series & $\$ 6,350$ \\
\hline IJHC/UTS & SW846 - $6010 \& 7470$ & - & $\$ 340$ \\
\hline SVOAVOAS & - & SW $846-8270 B$ \& $8260 A$ & $\$ 645$ \\
\hline
\end{tabular}




\begin{tabular}{|c|c|c|c|}
\hline Analysis & Preparation Method & Analytical Method & $\begin{array}{l}\text { Cost per Sample } \\
\text { (remote) }\end{array}$ \\
\hline Total Organic Carbon & - & EPA -9060 or Std $-5310-B, C$, or D & $\$ 47$ \\
\hline Total Suspended Solids & - & EPA -106.2 & $\$ 20$ \\
\hline Total Dissolved Solids & - & EPA -160.1 & $\$ 20$ \\
\hline $\mathrm{pH}$ & - & $\mathrm{EPA}-9040 \mathrm{~B}$ or $9045 \mathrm{C}$ & $\$ 10$ \\
\hline WIPP Data Validation & $\begin{array}{l}\text { TRU Waste Characterization } \\
\text { Sampling }\end{array}$ & WIPP Analysis - Manual & $\$ 64$ \\
\hline $\begin{array}{l}\text { WIPP Detailed Debris } \\
\text { Validation }\end{array}$ & & WIPP Analysis - Manual & $\$ 700$ \\
\hline $\begin{array}{l}\text { WIPP Detailed Sludge } \\
\text { Validation }\end{array}$ & & WIPP Analysis - Manual & $\$ 900$ \\
\hline $\begin{array}{l}\text { WIPP Production } \\
\text { Validation }\end{array}$ & & WIPP Analysis - Manual & $\$ 72$ \\
\hline Radiography & & Lab SOP & $\$ 44$ \\
\hline Passive Active Neutron & & Lab SOP & $\$ 44$ \\
\hline Gamma Spectrometry & & Lab SOP & $\$ 198$ \\
\hline Headspace Gas Analysis & SW $8468240 \& 8260$, EPA - T0-14 & ASTM D-2650-83, ASTM 1946-82 & $\$ 80$ \\
\hline Headspace QC & N/A & & $\$ 1,100$ \\
\hline
\end{tabular}


Appendix C

Waste NDA Capabilities/Limitations

C-1 


\section{Appendix C \\ Waste NDA Capabilities/Limitations}

\section{C-1. Introduction}

In general, NDA systems currently in use for waste assay have not been proven effective for TRU sludge matrices and a sizeable fraction of the debris waste forms in inventory. The shift from the nondestructive assay standaris compensation paradigm to alternate methods has not been made, hence limitations associated with compensation techniques are inherent in present day waste NDA methods. There are also fundamental limitations associated with the instrumentation utilized in waste NDA. Radiation emission properties of many waste forms are not compatible with the instrumentation and techniques available. An accepted means of quantifying all measurement uncertainty components associated with a given techrique is necessary for the demonstration and implementation of a viable method for characterizing weste. Until a clearly defined mechanism is developed which accounts for all elements of uncertainty in the assay of waste entrained radionuclide mass/activity, compliance demonstration will consume excessive resources ultimately effective for only a relatively small fraction of the waste form inventory.

This section delineates known attributes of actual waste forms which impede the application of NDA techniques and addresses the limitations of present waste NDA methods with respect to such attributes. Once this basis is established, waste NDA limitation/capability statements are made with respect to treatability categories. Additionally, capability statements are made with respect to compliance with QAPP requirement criteria and associated QAOs. The majority of such statements are general and bounding in nature as quantitative data on system capability is difficult to come by because few, if any, NDA systems have been rigorously evaluated for specific waste forms in terms of QAPP requirements. Despite the paucity of data, some information is available at various levels of detail for several waste $\mathrm{NDA}$ techniques regarding certain waste forms. Information on waste NDA system capability can also be derived from first principles of the detection methods, signal processing, and data reduction routines. For the most part available data acquired from specific waste NDA capability studies support inferences based on first principles.

The commonly applied standards compensated technique can be justified when the sample configuration is consistent with the calibration or reference configuration. Minor discrepancies between the sample and calibration configuration can be managed provided that the type and magnitude of variations are known and corrections or adjustments are clear and defensible. In those cases where the sample variation cannot be established or bounded per sample, more sophisticated methods of accounting for induced bias and precision ccmponents must be devised. Present day waste NDA methods have implemented a variety of simple techniques to account for unknowns in sample configuration relative to some reference base. Such methods generally rely on assumptions and correlations between some acquired measure to establish some type of sample dependent correction factor. Due to the variability of typical waste form configurations and the inherent dynamics of waste NDA instrumentation, nonunique and difficult to justify solutions can and do result from such approaches. Additionally, commonly employed detection techniquiss have fundamental limitations in terms of interference tolerances in the form of count rate, energy/tine resolution, etc. When such tolerances are exceeded, the use of the technique for waste forms possessing the interfering or complicating factor(s) is invalid. Waste assay systems should therefore include diagnostic techniques which indicate when attributes and parameter values associated with a given waste container exceed the system limitations. 


\section{C-2. NDA System Interference Sources}

In general, factors which complicate waste NDA techniques can be categorized by waste matrix/source attribute. Such attributes can subsequently be associated with waste codes or treatability groups. A knowledge of the interfering or complicating effect of such attributes on implemented waste NDA techniques allows one to pose statements with respect to existing waste NDA capability as a function of treatability category. A set of general waste form attributes with the potential for interference are listed below. Depending on waste NDA system design, the relative magnitude of the interference effect can vary. Regardless, each attribute represents a potential complication for which no well developed and accepted method exists to quantify and correct instrument response. For the purpose of this discussion, waste form attributes which represent complicating effects are separately categorized as source induced and matrix induced. Further, some combinations of source and matrix characteristics can result in interference sources not present in the either the matrix or source alone, e.g. an interfering (alpha, $n$ ) neutron source is generated when source emitted alpha particles are incident on light elements present in the matrix. The following is a tabulation of waste form attributes known to represent an interference effect to commonly employed waste NDA techniques.

Radioactive source related complicating factors:

- Variation in source radionuclide composition - Variation present from drum to drum and at different volume elements within a given drum. This variable requires the availability of defensible means of acquiring source composition data on a drum and volume element basis. Because the source radionuclidic composition can vary dramatically, i.e. ${ }^{235} \mathrm{U} /{ }^{241} \mathrm{Am} / \mathrm{WG}$ Pu ratios can vary in virtually any conceivable manner, an appropriate means of quantifying the absolute and/or relative ratios is necessary. Because the gamma lines most suitable for determining such ratios are closely spaced in energy, it is often the case that they interfere with each other defeating the most readily available analytical technique, gamma spectroscopy.

- Variation in source configuration - TRU material distributions, i.e., diffuse, aggregate, lumps and combinations thereof result in active interrogation self shielding and passive self attenuation effects. Clumping of fissile material can also produce neutron multiplication effects at higher mass loadings affecting measurement uncertainty.

- Chemical composition of source material - Depending on the chemical compound of the fissile material, various reactions can result yielding interfering radiations. The most common is the (alpha, $n$ ) effect where alpha particles incident on light elements yield a single neutron interfering with the standard passive neutron coincidence counting technique.

- Spatial distribution of source material - The physical distribution of the source material relative to the NDA system detection assemblies and the matrix within the waste container affects system response: The net effect is that a means to correct for variations in instrument response due to source spatial distribution is required.

- Characteristic radiation emission rate - The emission rate of characteristic radiation, gamma and/or neutron may or may not be within the capability of the waste NDA system. The yield of the characteristic radiation of interest may be low enough to cause detection limit concerns. High emission rates can lead to detector saturation and associated dead time determination and 
correction problems.

Waste matrix related complicating factors:

- Density - In general, the magnitude of waste NDA technique interference is proportional to matrix density. For example, as waste form density increases, the matrix attenuation of passively emitted characteristic radiations increases complicating interpretation and causing progressively larger correction factors to be applied. Attenuation is not solely a property of increasing density. There are many matrix elemertal compositions of relatively low density which have high attenuation coefficients for specific gamma ray and neutron energies, e.g. the concentration of ${ }^{10} \mathrm{~B}$ in borosilicate glass type matrices is sufficient to significantly impact active thermal neutron interrogation techniquesi even at low volume averaged densities.

- Density distribution - Uniform matrix distributions are most readily accounted for through the development of applicable calibrations. Heterogeneous density distributions are not well accommodated by waste NDA techniques and generally result in improper signal averaging for quantitative determinations and associated correction factor derivations.

- Elemental composition - There is a strong relationship between waste form elemental composition and interaction cross-sestion for characteristic radiations employed in waste NDA. Absorption and scattering cross-section: for gamma rays and neutrons vary dramatically as a function of elemental type and density. Composite waste form elemental configurations further complicate the derivation of useable corrections. Moderating and absorbing properties of waste forms affect neutronics of the system interfering with interpretation of acquired signals. The interaction of source and matrix is also a function of the elemental composition. For example, uncorrelated (alpha, $\mathfrak{n}$ ) neutron sources can be produced by source emitted alpha particles incident on light elements such as boron. The elemental composition also impacts active neutron interrogation methods. The presence of strong absorber elements can seriously impact the interrogation flux profile produced in the waste container matrix complicating interpretation.

The above tabulation of interlere sources is by no means all inclusive but serves to point out several prevalent waste form attributes complicating present day waste NDA techniques. Waste NDA systems for the most part do not have reliable instrument response characteristics useful for the quantification of such interferences. This leads to a reliance on the use of assumptions which are difficult to justify in terms of their applicability.

\section{C-3. Waste NDA Capability by Treatability Group}

In order to relate waste NDA system capability to treatability group, the matrix parameter category (MPC) which describes the overall physical/chemical form of the waste must be evaluated with respect to the response characteristic:; of the various NDA techniques. Evaluated MPCs are those associated with the sludge and debris waste forms. The evaluation consists of qualitatively identifying and classifying waste form configuration source and matrix attributes per MPC. The various waste NDA techniques, either implemented or in development, are also qualitatively assessed in terms of capability and performance with respect to the set of attributes characteristic of the sludge and debris MPCs. Based on this scheme, a nominal NI)A system capability classification per MPC tabulation is generated. 
The MPC capability classification of a given waste NDA technique is necessarily qualitative as the majority of matrix/source MPC characteristics and MPC attribute to technique correlation assignments are, in general, based more on experience and first principles versus actual experimental data. Although well defined studies and hard experimental evidence of NDA system capability as a function of MPC is desirable, few referencable documents of this nature are available. Regardless, an approximation of NDA capability per MPC can be gleaned from the qualitative analysis presented below. A description of the waste forms contained in the sludge and debris MPCs for which the NDA capability is evaluated is presented followed by the capability estimation process and results (Tables C-1 through C-3).

\section{C-3.1 Evaluated Waste Form Description}

The following two subsections provide a summary description of the sludge and debris waste form generation process and as packaged matrix configuration. This information forms a basis for classifying matrix and source attributes per MPC. The matrix/source attributes of the various MPCs are also used to evaluate technique response and performance.

C-3.1.1 Sludge Waste Forms. Sludges are under the category of homogenous solids with a "Level $1000 "$ MPC of S3000. Homogeneous solids may include water, residue or absorbed liquids. Sludge is further evaluated per the criteria of inorganic homogeneous solids $\mathrm{S} 3100$ and organic homogeneous solids S3200 summary categories. The majority of INEEL sludge waste forms fall into the S3100 MPC. Representative waste forms for the $\mathrm{S} 3120$ detailed MPC category are wastewater treatment sludge (S3121) corresponding to item description codes (IDCs) 001, 002, 007, 800, 803, 807, 818 which comprise a sizable fraction of the INEEL RWMC sludge inventory. Other INEEL RWMC sludge waste forms such as IDCs $003,004,700,801$, are assigned detailed MPC S3114, absorbed organic liquids. These MPCs, S3121 and S3114, are the basis for discussing waste NDA capability for the sludge waste form.

Sludge IDCs 001 and 003 serve as representative matrix types for all sludge types for the purpose of delineating those attributes which affect the NDA of sludge waste forms. IDC 001 is a wet sludge precipitate generated by processing liquid wastes such as ion exchange column effluents, distillates, caustic soda solution etc., from the Plutonium Recovery Operations (Bldg 771), Rocky Flats Plant. When required, the various sources of liquid waste are made basic using sodium hydroxide. The plutonium and americium is scavenged from the liquid by a carrier-hydroxide precipitation process. Coagulating agents, $\mathrm{Fe}\left(\mathrm{SO}_{4}\right)_{3}, \mathrm{MgSO}_{4}$, and $\mathrm{CaCl}_{2}$ are added to form the precipitate which is subsequently filtered. The treatment process produces a precipitate of the hydrated oxides of iron, magnesium, aluminum, silicon, etc., which also carries the hydrated oxides of plutonium and americium. The precipitate or slurry is filtered to produce a sludge containing 60 to 70 weight percent of water resulting in a consistency similar to paste or mortar.

The IDC 001 configuration contains many of the attributes identified above as interfering agents with respect to waste NDA techniques. Each packaged 55 gallon drum weighs on the order of 400 to 500 pounds with a density of approximately $1.0 \mathrm{~g} / \mathrm{cm}^{3}$. The matrix configuration is nominally 65 percent weight percent $\mathrm{H}_{2} \mathrm{O}$ with significant fractions of light elements such as oxygen and aluminum. The relative radionuclidic ${ }^{235} \mathrm{U} /{ }^{241} \mathrm{Am} / W \mathrm{WG}$ Pu ratio varies from drum to drum as well as spatially within the same drum. The concentration of the source material also varies as a function of position in a given sludge drum. Because the sludge is formed as a precipitate, the source material is diffuse in nature and problems encountered with fissile material clumping are not present. The elemental composition of the 
sludge also varies as a function of position in the drum and is not consistent from drum to drum. Neutron absorbers such as chlorine are also present in appreciable quantities.

The situation with IDC $003 \mathrm{i}$ is not much different than indicated for IDC 001 . There is a lesser hydrogen content but an increased chlorine content which is detrimental to neutron based systems. IDC 003 is categorically referred to as absorbed organic liquids, detailed MPC S3114. The generation source of INEEL stored IDC 003 sludge is the Aqueous Waste Treatment Facility which processes organic wastes generated at the various plutonium and nonplutonium operational areas at the Rocky Flats Plant. The organic waste forms generated as a byproduct of plutonium fabrication operations are primarily comprised of trichloroethane, carbon tetrachloride, machining and hydraulic oils. The hydraulic and machining oils are classified as Texas Regal oil. Organic wastes from nonplutonium areas includes similar components including carbon tetrachloride, trichloroethylene, tetrachloroethylene, trace concentrations of organophosphates and nitrobenzene, and hydraulic and gearbox oils. Freon is also a significant component of the organic liquid in ODC 003 sludge estimated at 6.0 percent by mass. Unknown quantities of polychlorinated biphenyls were also processed in addition to the typical organic waste through 1979.

Organic waste is processed for packaging by blending approximately 30 gallons of organics with 100 pounds of calcium silicate in a continuous mixer. Oil-Dry compound was typically included in the blending process at a mass of: approximately 15 pounds per drum. The resultant blending process product is a sludge material with a semi-solid paste or grease consistency. A four pound mass of Oil-Dri is placed in the bottom of the 55-gal drum to absorb potential oil migration from the two plastic 65-gal drum bags which are subsequently used to line the drum. Each of these bags also has four pounds of OilDri placed in them prior to dispensation of the solidified sludge material. Oil-Dri is also added to the top of the outer bag after the sluclge has been dispensed.

All of the complicating factors mentioned for IDC 001, e.g. density, are associated with the IDC 003 precluding a viable waste NL)A capability for this waste form.

C-3.1.2 Heterogenous Deliris Waste Forms. The debris waste summary category, S5000, includes waste that is at least 50 percent by volume materials that meet the following EPA LDR debris classification criteria. Solid material exceeding a $60 \mathrm{~mm}$ particle size that is intended for disposal and that is: 1) a manufactured object, or 2) plant or animal matter, or 3) natural geologic material. The balance of the material may be other physical or chemical waste forms. This waste category is further evaluated per the criteria of the inorganic debris (S5100), organic debris (S5300), and heterogeneous debris (S5400).

This section addresses NDA limitations and capabilities with respect to heterogeneous debris (S5400). The heterogeneous debris summary category includes waste that is at least 50 percent by volume debris materials that do not meet the criteria as either organic or inorganic debris. INEEL contact handled waste forms with heterogenous debris MPCs include S5420, S5440 and S5410 which span IDCs, 335, $337,338,360,374,376,464$ and 490 .

The general description applied to IDC 335 is absolute filters originating from the Rocky Flats facility. These filters were utilized on the air intakes and exhausts of glove box lines. The actual composition of the filters consists of wood and particle board with asbestos type filter media. The waste matrix also contains combustibles type materials such as polyethylene bagging and surgeons gloves at an estimated 
weight fraction of 15 percent. IDC 338 is not as clearly defined as IDC 335 but consists of filter media, asbestos type pipe insulation, asbestos gloves and fire blankets. Other materials such as aluminum and wood filter frames are also present in limited quantities.

IDC 376 is categorized as cemented insulation and filter media. IDC 490 consists primarily of assembled high efficiency particulate air filters and prefilters utilized on all ventilation intake and exhaust systems. The HEPA filters are typically comprised of wooden frames and asbestos and fiberglass type filter media. Some filter frames are constructed from aluminum. IDC 490 drums packaged prior to 1976 may also contain chemical warfare service filters.

IDC 302 and 464 both consist of Benelex hardboard, Plexiglas, limited amounts of lead, wood, metal, rubber gaskets, gloves and packaging materials. The materials found in these drums originated from maintenance and renovation projects associated with Plutonium Recovery Operations, building 771 . Benelex is a dense laminated hardboard composed of wood fiber, paraffin wax, and a phenolic resin. Benelex was primarily used attached to glove box structures because of its chemical resistance and shielding properties. It generally took the form of two inch thick sheets but was sometimes laminated up to four inch thicknesses. To enhance the shielding characteristics of Benelex hardboard, it was commonly found covered with lead sheeting from $1 / 8$ to $1 / 4$ inch thick and treated with a fire retardant paint. Review of real-time radiographic (RTR) images and TRU Waste Sampling Program videotapes revealed that the majority of Benelex boards are 4 inches by 12 inches by 15 inches or larger. These Benelex pieces are typically packed with Plexiglas bundles resulting in a relatively high drum volume utilization $(>60 \%)$. Plexiglas is a transparent thermoplastic polymer of methyl methacrylate. It was used at the RFP for glove box windows and a variety of assemblies. It occurs in waste drums in various sizes and shapes. Review of the RTR examination images and the TRU Waste Sampling Program videotapes showed the Plexiglas to be stacked $1 / 2$-inch thick sheet material in rectangular bundles with typical dimensions of 6 inches by 12 inches by 18 inches. In some cases the glove box rubber gaskets are still attached to the Plexiglas. The individual Plexiglas bundles are typically double bagged in polyethylene.

The IDC 330 matrix consists of process line and non-line generated dry combustible materials such as paper, rags, plastics, surgeon's gloves, cloth overalls, cardboard, wood, wood filter frames, polyethylene bottles, etc. It is also a potential that damp and moist combustible materials as identified are present. IDC 337 is also similar to IDC 330 with the addition of polyvinyl chlorides (PVCs), Teflon, and nonleaded rubber items. Visual RTR evaluations are of particular importance to the interpretation of neutron system response is the presence of small, extremely dense chips and chunks of metal entrained in the waste matrix. These chunks are identified in approximately 30 to 40 percent of the drums examined and are typically found in a random distribution throughout the bottom one third portion of the drum. Detailed evaluations of drums exhibiting such dense materials have led to the conclusion that they consist of plutonium and/or uranium. The identification of these small pieces of fissile material metal or oxide clumps is important to NDA considerations in that they essentially invalidate the use of the active neutron interrogation mode as currently configured due to self shielding effects.

\section{C-3.2 Waste Matrix/Source Attribute to NDA Technique Correlation}

Based on evaluations of waste form configurations associated with the tabulated MCPs, it is possible to correlate matrix/source attributes to MPC via a parameter descriptive of the distribution. A qualitative correlation between matrix/source attributes and MPCs based on nominal MPC population characteristics is provided in Table $\mathrm{C}-1$. The correlation parameters are a function of those waste matrix/source attributes known to interfere with and complicate waste NDA measurement techniques. 
For example, the correlation parameter used to relate source radionuclide composition variation to an MPC category is the prevalence of variability in the composition. Other correlation parameters employed are a density scale, high, medium and low and a descriptor of heterogeneity addressing material type and void combinations typical of an MPC category container packaging. The parameters as defined and assigned in Table C-1 are based on nominal distributions derived from knowledge of waste form configurations. The assignments are in no way applicable to every container within a given MPC. For example, the source configuration variation, i.e. diffuse, aggregate, clumps and combinations thereof, correlation paramete: for MPC S3120 is assigned as invariant. This in no way indicates that a drum with a variation in source configuration relative to the balance of the population is not present.

After establishing a relations.hip between the MPC categories and waste matrix/source attributes, it is necessary to derive some qualitative correlation between NDA technique capability/performance and the previously defined matrix/solurce attributes. This is established in Table C-2 through the use of correlation parameters addressing the need for supplemental data/information, ability to detect attribute and capability to correct, whether there is a response to the attribute where necessary, and whether the attribute manifests itself as an interference or not. Grading the response of an NDA technique with respect to waste matrix/source attribute and folding the result with the Table C-1 matrix/source attribute prevalence per MPC allows an estimation of NDA system capability per MPC. 
Table C-1. Correlation of waste form attribute to MPC.

\begin{tabular}{lcccccccccc}
\hline \multicolumn{1}{c}{ Waste Form Attribute } & \multicolumn{1}{c}{ Matrix Parameter Categories } \\
\hline & $\mathrm{S} 3120$ & $\mathrm{~S} 3140$ & $\mathrm{~S} 3200$ & $\mathrm{~S} 4000$ & $\mathrm{~S} 5111$ & $\mathrm{~S} 5112 / 13$ & $\mathrm{~S} 5120$ & $\mathrm{~S} 5311$ & $\mathrm{~S} 5312 / 13$ & $\mathrm{~S} 5400$ \\
$\begin{array}{l}\text { source radionuclide composition } \\
\text { variation }\end{array}$ & $\mathrm{V}$ & $\mathrm{V}$ & $\mathrm{V}$ & $\mathrm{V}$ & $\mathrm{V}$ & $\mathrm{V}$ & $\mathrm{V}$ & $\mathrm{V}$ & $\mathrm{V}$ & $\mathrm{V}$ \\
source configuration variation & $\mathrm{I}$ & $\mathrm{O}$ & $\mathrm{I}$ & $\mathrm{I}$ & $\mathrm{O}$ & $\mathrm{O}$ & $\mathrm{O}$ & $\mathrm{O}$ & $\mathrm{V}$ & $\mathrm{O}$ \\
source chemical composition & $\mathrm{V}$ & $\mathrm{V}$ & $\mathrm{V}$ & $\mathrm{V}$ & $\mathrm{V}$ & $\mathrm{V}$ & $\mathrm{O}$ & $\mathrm{V}$ & $\mathrm{O}$ & $\mathrm{V}$ \\
source spatial distribution & $\mathrm{O}$ & $\mathrm{V}$ & $\mathrm{O}$ & $\mathrm{V}$ & $\mathrm{V}$ & $\mathrm{V}$ & $\mathrm{V}$ & $\mathrm{V}$ & $\mathrm{V}$ & $\mathrm{V}$ \\
matrix density & $\mathrm{H}$ & $\mathrm{H}$ & $\mathrm{H}$ & $\mathrm{H}$ & $\mathrm{M}$ & $\mathrm{M}$ & $\mathrm{M}$ & $\mathrm{M}$ & $\mathrm{L}$ & $\mathrm{L}$ \\
matrix density distribution & $\mathrm{I}$ & $\mathrm{V}$ & $\mathrm{I}$ & $\mathrm{O}$ & $\mathrm{V}$ & $\mathrm{V}$ & $\mathrm{V}$ & $\mathrm{V}$ & $\mathrm{O}$ & $\mathrm{O}$ \\
matrix elemental composition & $\mathrm{V}$ & $\mathrm{O}$ & $\mathrm{O}$ & $\mathrm{V}$ & $\mathrm{V}$ & $\mathrm{V}$ & $\mathrm{V}$ & $\mathrm{V}$ & $\mathrm{O}$ & $\mathrm{O}$ \\
matrix heterogeneity & $\mathrm{F}$ & $\mathrm{N}$ & $\mathrm{F}$ & $\mathrm{N}$ & $\mathrm{C}$ & $\mathrm{C}$ & $\mathrm{C}$ & $\mathrm{N}$ & $\mathrm{N}$ & $\mathrm{C}$ \\
\hline
\end{tabular}

V - variable (prevalent characteristic)

$\mathrm{O}$ - occasionally variable

I - invariant

$\mathrm{H}-\mathrm{high}(>0.65)$

$\mathrm{M}$ - medium $(0.3$ - 0.65$)$

$\mathrm{L}$ - low $(<0.3)$

C - many material types/voids

$\mathrm{N}$ - nominal number of material types/voids

$\mathrm{F}$ - few material types/voids

a. Descriptive parameters based on population average only, distribution variance dictates actual number of individual drums with attribute as defined. 
Table C-2. Qualitative waste matrix/source attribute to NDA technique correlation.

\begin{tabular}{|c|c|c|c|c|c|c|c|c|}
\hline \multirow[t]{2}{*}{ Waste Form Attribute } & \multicolumn{8}{|c|}{ Measurement Technique } \\
\hline & $\begin{array}{l}\text { Gamma } \\
\text { SGS }\end{array}$ & $\begin{array}{l}\text { Gamma } \\
\text { TGS }\end{array}$ & $\begin{array}{c}\text { Passive } \\
\text { Neutron } \\
\text { Coin. } \\
\end{array}$ & $\begin{array}{c}\text { Passive } \\
\text { Neutron } \\
\text { Coin. (AMC) }\end{array}$ & $\begin{array}{c}\text { Total } \\
\text { Neutron }\end{array}$ & $\begin{array}{c}\text { Active } \\
\text { Cf } \\
\text { Shuffler }\end{array}$ & $\begin{array}{c}\text { Active } \\
\text { Diff. } \\
\text { Die-away } \\
\end{array}$ & $\begin{array}{c}\text { Active } \\
\text { thermal } \\
\text { epitherm }\end{array}$ \\
\hline $\begin{array}{l}\text { source radionuclide } \\
\text { composition variation }\end{array}$ & B & $\mathrm{C}$ & $\mathrm{E}, \mathrm{A}$ & $\mathrm{E}, \mathrm{A}$ & E,A & $\mathrm{E}, \mathrm{A}$ & $\mathrm{E}, \mathrm{A}$ & $\mathrm{E}, \mathrm{A}$ \\
\hline 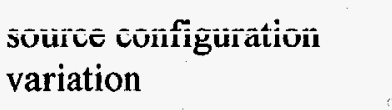 & B & $\mathrm{C}$ & $\mathrm{F}$ & F & F & $\mathrm{E}, \hat{\mathrm{A}}$ & $\mathbf{E}, \hat{\mathbf{A}}$ & $\mathrm{B}$ \\
\hline $\begin{array}{l}\text { source chemical } \\
\text { composition }\end{array}$ & F & $\mathrm{F}$ & B & B & $\mathrm{E}, \mathrm{A}$ & $\mathrm{F}$ & $\mathrm{F}$ & $\mathrm{F}$ \\
\hline $\begin{array}{l}\text { source spatial } \\
\text { distribution }\end{array}$ & $\mathrm{C}$ & $\mathrm{D}$ & $\mathrm{B}, \mathrm{C}$ & $\mathrm{B}, \mathrm{C}$ & B & $\mathrm{B}, \mathrm{C}$ & $\mathrm{B}, \mathrm{C}$ & $\mathrm{B}, \mathrm{C}$ \\
\hline matrix density & $\mathrm{C}$ & $\mathrm{D}$ & $\mathrm{E}, \mathrm{A}$ & $\mathrm{C}$ & $\mathrm{E}, \mathrm{A}$ & $\mathrm{E}, \mathrm{A}$ & $\mathrm{C}, \mathrm{A}$ & $\mathrm{C}, \mathrm{A}$ \\
\hline $\begin{array}{l}\text { matrix density } \\
\text { distribution }\end{array}$ & $\mathrm{C}$ & $\mathrm{D}$ & $\mathrm{E}, \mathrm{A}$ & $\mathrm{C}$ & $\mathrm{E}, \mathrm{A}$ & $\mathrm{E}, \mathrm{A}$ & $\mathrm{C}, \mathrm{A}$ & $\mathrm{C}, \mathrm{A}$ \\
\hline $\begin{array}{l}\text { matrix elemental } \\
\text { composition }\end{array}$ & $\mathrm{B}, \mathrm{A}$ & $\mathrm{B}, \mathrm{A}$ & $\mathrm{E}, \mathrm{A}$ & $\mathrm{C}, \mathrm{A}$ & E,A & $\mathrm{E}, \mathrm{A}$ & $\mathrm{C}, \mathrm{A}$ & $\mathrm{C}, \mathrm{A}$ \\
\hline matrix heterogeneity & $\mathrm{B}, \mathrm{A}$ & $\mathrm{B}, \mathrm{A}$ & $\mathrm{B}, \mathrm{A}$ & $\mathrm{C}, \mathrm{A}$ & $\mathrm{E}, \mathrm{A}$ & $\mathrm{E}, \mathrm{A}$ & $\mathrm{B}, \mathrm{A}$ & $\mathrm{B}, \mathrm{A}$ \\
\hline \multicolumn{9}{|c|}{$\begin{array}{l}\text { A - requires supplemental data/information } \\
\text { B - can detect parameter, inadequate correction } \\
\text { C - can detect parameter, partial correction } \\
\text { D - can detect parameter, reasonable correction } \\
\text { E - no response to parameter } \\
\text { F - no significant perturbation of technique }\end{array}$} \\
\hline
\end{tabular}




\section{C-4. Estimated NDA Capability}

The utility of existing waste NDA technologies can be expressed as either a capability regarding a given MPC or conversely as possessing a limitation per MPC. Classification of system utility per MPC is expressed in terms of a useful or applicable capability, a nominal or potential capability, a limited capability, and a minimal or questionable value capability. An applicable capability refers to an existing NDA technique which can accommodate a reasonable fraction of an MPC population without the need for ancillary analyses and technical resources hence warranting consideration of the technique for implementation. A nominal or potential capability indicates that some lesser fraction of an MPC inventory could be characterized using the technique provided strict controls have been implemented to ensure a given container from the MPC population is compatible with the technique. A limited capability refers to one for which the technique itself requires significant analytical resources and development of supportive data/techniques to substantiate the quality of the assay. A minimal capability refers to an NDA system which requires significant information resources independent of the measurement data for interpretation which is difficult to derive. A minimal capability is in general of questionable utility in that the required supportive information is likely not available and/or substantiative for compliance purposes.

The interpretation of Table C-3 regarding existing NDA capability per MPC category is based on the nominal MPC category waste matrix/source attributes and NDA technique capability. With reference to the nominal waste form configuration and NDA system capability, it is readily noted that there is no outstanding capability inherent in any of the existing techniques for the sludge and debris MPC categories without some degree of supportive technical analyses. This needs to be qualified somewhat in that the nominal waste form configuration used in the evaluation contains the interfering attribute which is associated with the MPC and technique. This does not indicate that the capability assigned to a given NDA technique applies to each and every drum in the MPC population. There is a distribution of attribute magnitude residing in each MPC. Therefore drums exist within an MPC which do not exhibit interference sources at a value which impedes instrument utility. This effectively states that if there is a means to identify attributes associated with each individual drum within an MPC subjected to an assay, then it is possible to segregate those drums which are within the capability of the technique from those which are not. Hence, there is some fraction of the MPC population which can be viably assayed despite the overall assignment of an apparently poor capability to certify in accordance with quality assurance requirements. 
Table C-3. NDA technique capability qualification per MPC category.

\begin{tabular}{|c|c|c|c|c|c|c|c|c|c|c|}
\hline \multirow[t]{2}{*}{ Measurement Technique } & \multicolumn{10}{|c|}{ Matrix Parameter Categories } \\
\hline & S3120/14 & $\mathrm{S} 3140$ & S3200 & S4000 & S5111 & S5112/13 & S5120 & S5311 & S5312/13 & $\mathbf{S 5 4 0 0}$ \\
\hline $\begin{array}{l}\text { High Resolution Gamma Spectroscopy } \\
\text { Systems (segmented \& tomographic) }\end{array}$ & M & $\mathrm{N}$ & M & $\mathbf{M}$ & L & $\mathrm{L}$ & $\mathbf{L}$ & M & $\mathbf{N}$ & $\mathrm{L}$ \\
\hline \multicolumn{11}{|l|}{ Passive Neutron Measurements } \\
\hline passive coincidence & $\mathbf{M}$ & $\mathbf{M}$ & $\mathbf{M}$ & $\mathbf{N}$ & $\mathbf{N}$ & $\mathbf{N}$ & $\mathbf{N}$ & $\mathbf{N}$ & $\mathbf{N}$ & $\mathbf{N}$ \\
\hline $\begin{array}{l}\text { advanced high efficiency matrix } \\
\text { corrected passive coincidence }\end{array}$ & $\mathbf{M}$ & $L$ & $\mathbf{M}$ & $\mathbf{N}$ & A & $\mathrm{N}$ & $\mathrm{N}$ & $\mathbf{N}$ & $\mathrm{N}$ & $\mathrm{N}$ \\
\hline \multicolumn{11}{|l|}{ Active Neutron Measurements } \\
\hline delayed-neutron counting (shuffler) & $\mathrm{L}$ & $\mathbf{M}$ & $\mathbf{L}$ & $\mathbf{L}$ & $\mathbf{L}$ & $\mathrm{L}$ & $\mathbf{L}$ & $\mathbf{L}$ & $\mathbf{L}$ & $\mathbf{L}$ \\
\hline $\begin{array}{l}\text { random source driven coincidence } \\
\text { counter }\end{array}$ & $\mathrm{L}$ & $\mathbf{M}$ & $\mathrm{L}$ & $\mathbf{L}$ & $\mathbf{L}$ & $\mathrm{L}$ & $\mathrm{L}$ & $\mathbf{L}$ & $\mathbf{L}$ & $\mathbf{L}$ \\
\hline differential die-away & $\mathrm{L}$ & $\mathbf{M}$ & $\mathrm{L}$ & $\mathbf{L}$ & $\mathbf{L}$ & $\mathbf{L}$ & $\mathbf{L}$ & $\mathbf{L}$ & $\mathbf{L}$ & $\mathrm{L}$ \\
\hline thermal/epithermal interrogation & $\mathbf{L}$ & $\mathbf{M}$ & L & $\mathbf{L}$ & $\mathbf{L}$ & $\mathbf{L}$ & $\mathbf{L}$ & $\mathbf{L}$ & $\mathbf{L}$ & $\mathbf{L}$ \\
\hline \multicolumn{11}{|c|}{$\begin{array}{l}\text { A - applicable capability, utility of technique viable as is } \\
\mathrm{N} \text { - nominal capability, viability dependent on knowledge of matrix/source attributes to define subpopulation within system capability } \\
\mathrm{L} \text { - limited capability, requires implementation of supportive technique and ancillary analyses } \\
\mathrm{M} \text { - minimal capability, ability to derive necessary supportive data impeded by technique and availability of information }\end{array}$} \\
\hline
\end{tabular}


With respect to the capability of waste NDA techniques regarding the sludge waste form it is relatively safe to state that without the availability of supportive data, i.e. radionuclidic/isotopic composition, source spatial information, etc there is little or no existing NDA capability. The sludge matrix possesses nearly every complicating factor for waste NDA systems possible in one matrix. An application of gamma based systems such as segmented gamma scanning and computed tomographic methods is limited primarily due to the density and presence of several differing radionuclides with similar gamma decay energies. The determination of isotopic using high resolution gamma spectroscopy is further complicated when the radionuclidic/isotopic ratios lead to significant masking of other radionuclide signature lines. An accounting of the varying spatial distribution of the source composition is limited due to the high density. The situation is not improved for neutron based system, either active or passive. The passive neutron coincidence signal is overwhelmed by the uncorrelated singles (alpha, $n$ ) component in addition to being moderated and stretched out in time by the high hydrogen content of the sludge. Active neutron interrogation is equally of limited value in that the flux profile is extremely nonuniform and unknown due to moderation and absorption processes. Neutron transport studies confirm that the active system induced thermal neutron interrogation flux profile is not uniform throughout the drum volume and variable as a function of sludge composition and density distribution. Such computations are supported by destructive radiochemistry data acquired by extracting core samples from sludge drums on which NDA measurement have been acquired. Hence it is an apparent necessity that ancillary analysis methods be developed to support the NDA of sludge waste forms using currently available technologies.

Debris waste forms represent somewhat less of an overall complication to existing waste NDA techniques. The density is for the most part much lower than that of sludge and the radionuclidic composition is on average less variable than that of sludge. There are other complications in debris waste forms which are not prevalent in the sludge waste form, in particular dense aggregates of fissile material particulate and large individual clumps of such material. Such source configurations effectively nullify the use of active neutron interrogation systems. Passive neutron type systems are reasonably reliable providing that the (alpha, $n$ ) component of the source characteristic radiation is below the tolerance limit of the particular system. Gamma based systems also have a reasonable opportunity to manage debris type waste forms given the density is on the order of 0.35 or less and clumps of fissile material are not the predominant source configuration within a given drum.

In summary, it is not possible to build a good technical defense for demonstrating compliance with the QAPP QAOs, in particular the total uncertainty QAO, for a significant fraction of the sludge and debris inventory using as is waste NDA technologies alone. Supportive data regarding the waste form matrix/source composition and configuration is required for the majority of cases to complete data interpretation and specify total uncertainty. There are waste drums containing configurations that are not quite as hostile as the nominal composite used in this evaluation, which if properly identified could be assayed with reasonable success. The key is to be able to readily identify drum with attributes within the capability of a given NDA technique.

\section{C-5. Criticality Control Section Data}

Process monitoring systems are commonly based on a design specification which is predicated on a functional and operational requirement document. Cost estimates for process monitoring equipment acquired as off-the-shelf units complying with identified requirements initially appears straightforward particularly if the system is a standalone integral instrument. It is more often the case that the acquisition of a given monitoring instrument entails the procurement of several components which are subsequently tested, assembled into a specified configuration and installed into a facility process 
component, i.e. effluent stack, transfer line, etc. The configuration is typically driven by the process environment in which the instrument is to operate as well as associated performance requirements. The sequence of events to achieve an installed operation ready monitoring instrument nominally includes a function and requirements definition, design specification/drawings, resource scheduling/materials procurement, component testing and assembly, integrated system function and performance testing, process integration design and associated modifications, installation, interface to the plant control and protection systems, final as :nstalled testing and documentation. Quality assurance review and acceptance activities are assiciated with the entire process from the determination of functional and operational requirements to final instrument performance testing and transfer to the facility operations organization.

Depending on the monitoring instrument function and its importance to safety and environmental protection, additional costs r.nay be incurred as a result of required analyses for safety system design and reviews by oversight committees and associated demonstrations. For example, criticality protection and holdup monitoring systems serve a safety and plant protection function. A criticality safety analyses assessing process component and composite facility criticality risk for all phases of operation must be performed. From the safety analyses a control plan is derived defining allowable operational parameters regarding fissile material holdup. Based on the complexity of the facility, such an analysis can require well in excess of one million dollars. In consideration of the various factors which must be accounted for per monitor system installation, it is clear that cost estimates based on an aggregate of-the-shelf component cost will be an underestimate. Typically hardware expenses will be a minimal portion of the overall cost of an installed operational monitoring system. For this reason adjustments to material cost estimates are made to reflect process adaptation/integration engineering and implementation costs. 